\title{
CLEANING LABOR'S HOUSE: INSTITUTIONAL REFORM LITIGATION IN THE LABOR MOVEMENT
}

\author{
MichaEL J. GOLDBERG*
}

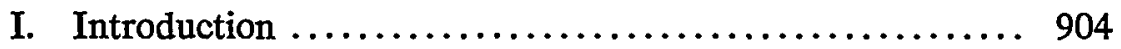

II. The Nature and Scope of Union Corruption and Labor Racketeering ................................ 909

III. Keeping Its Own House Clean: The Labor Movement's Internal Reniedies............................. 916

A. Discipline of Corrupt Officers and Members and Damage Actions for the Recovery of Embezzled Union Funds ...................................... 917

B. Voting the Rascals Out ........................ 919

C. Intra-Union Trusteeships ...................... 920

D. Other Intra-Union Controls Over Local Unions ....... 922

E. Public Review Boards ......................... 923

F. The Federation's Role ....................... 925

IV. Legal Authority for the Judicially Supervised Reform of Labor Unions ............................... 927
A. Traditional Equitable Remedies and the Emergence of Institutional Reform Litigation .................. 928
B. Common Law Union Receiverships, Before Landrum- Griffin ... and After........................ 931
C. Title VII and the Integration of Unions, Apprenticeship Programs, and Hiring Halls......... 938
D. State Regulation of Unions in the Longshore and
Casino Industries ............................. 941
E. The Reform of Union Pension and Welfare Funds .... 943

* Professor, Widener University School of Law. A.B. 1971, Cornell University; J.D. 1975, Harvard Law School; LL. M. 1977, Georgetown University Law Center. The author would like to thank Florian Bartosic, Herman Benson, G. Robert Blakey, Arthur L. Fox, Paul Alan Levy, Cornelius J. Peck, and Clyde W. Summers for their helpful comments on earher drafts. Many thanks also to Sharon Rau, Anthony Sanchez, and Susan McMarlin Vater for their invaluable research assistance.

In 1980-81, the author served as counsel to Teamsters for a Democratic Union (TDU), a national organization of rank-and-file Teamsters seeking to reform their umion. From time to time since then, he has served as a consultant to TDU on a pro bono basis. The views expressed in this Article, however, are those of the author alone and do not necessarily refiect those of TDU or any other organization. 
V. The Civil RICO Structural Injunction............... 946

A. Civil RICO ............................. 948

B. Aiding and Abetting the Extortion of Membership Rights ................................. 950

C. Accomodating Federal Labor Policy .............. 955

D. Freedom of Association ...................... 961

VI. The Remedies Applied at the Local Level ............. 965

A. Teamsters Local $560 \ldots \ldots \ldots \ldots \ldots \ldots \ldots \ldots \ldots . \ldots 65$

B. Cement \& Concrete Workers Local 6 A ............ 975

C. Teamsters Local 814 ....................... 977

D. Roofers Local 30 ......................... 980

VII. Remedial Alternatives at the National Level ........... 984

A. The Teamsters Board of Monitors ............... 984

B. Reorganization by Decree: The Teamsters' RICO

Settlement .............................. 994

VIII. Toward Maximizing Effectiveness While Minimizing Intrusiveness .................................. 1001

A. The Politics of RICO Trusteeships ................ 1001

B. Some Civil RICO "Sentencing" Guidelines .......... 1003

IX. Conclusion.................................. 1010

\section{INTRODUCTION}

Jimmy Hoffa is probably laughing in his landfill, ${ }^{1}$ amused by the fact that the more things change in his union, the more they stay the same. When Hoffa ascended to the presidency of the International Brotherhood of Teamsters (IBT) in 1958, that union was not only the largest and strongest in the American labor movenient, but also the most corrupt. Unfortunately, after three decades of effort by both rank-and-file reformers and federal law enforcennent officials to clean up the 1.6 inillion member union, that cliaracterization of the IBT reinains as accurate today as it was in Hoffa's day.

Hoffa became president of the Teamsters union following the decision of his predecessor, Dave Beck, not to run for reelection in the face of

1. Speculating about the whereabouts of Jimmy Hoffa is one of the favorite pastimes of Teamsters watchers like myself. Nobody has much doubt that Hoffa is dead. He disappeared in July of 1975, presumably murdered on the order of Mafia chieftans who felt threatened by his efforts to regain the union's presidency, which he was forced to relinquish several years earlier when he went to jail for jury tampering and pension fraud. The two leading theories are that Hoffa's body was mcinerated or "compacted" on the premises of a Michigan sanitation company, or that it was buried in the New Jersey meadowlands. For informed speculation about Hoffa's death and the reasons his former allies in organized crime turned against him, see S. BRILL, THE TEAMSTERS 43-75 (1978); L. Velie, Desperate Bargain: Why Jimmy Hoffa HaD to Die 12-49, 174-83 (1977). 
subsequently proven charges of embezzlement and tax evasion. ${ }^{2}$ Hoffa's election, the product of a rigged convention, was surrounded by controversy and was challenged in court, with surprising success, by rank-andfile reformers who managed to obtain the judicial appointment of a Board of Monitors to oversee what was to have been a major clean up of the union. ${ }^{3}$ At the same time, Hoffa and his associates were the targets of relentless governmental investigations and prosecutions for corruption and racketeering, ${ }^{4}$ which led to the IBT's expulsion from the AFL-CIO, ${ }^{5}$ passage of the Landrum-Griffin Act (the first comprehensive legislation regulating the internal affairs of unions), ${ }^{6}$ and eventually Hoffa's own conviction and imprisonment for jury tampering and pension fraud. ${ }^{7}$

It is now 1989, and not much has changed in the Teamsters union. Jimmy Hoffa is gone, to be sure, but the controversies surrounding his union remam remarkably similar. Jackie Presser, the late Teamsters president who recently died of cancer, gamed that office ouly after his predecessor, Roy Williams, was convicted on federal charges of attempting to bribe a U.S. Senator. ${ }^{8}$ And just as Hoffa helped clear a path for his own advancement by leaking information about Beck to the McClellan Committee, ${ }^{9}$ Presser apparently did the same by serving as an informant for the FBI and giving information on Williams. ${ }^{10}$ Moreover, evidence introduced in a marathon criminal trial of Genovese crime family bosses in New York, and statements obtained from both Williams and Presser, support Justice Department allegations that a Mafia conspiracy

2. R. JAMES \& E. JAMES, Hoffa AND the TEAMSTERS $19-20$ \& n. * (1965).

3. See infra text accompanying notes $492-567$.

4. The most important and wide-reaching of these investigations was conducted by the U.S. Senate's Select Committee on Improper Activities in the Labor and Management Field (the McClellan Committee) during 1957 and 1958.

5. See AFL-CIO's Expulsion of Three Unions, 41 L.R.R.M. (BNA) 37 (1958); Teamsters Suspended by AFL-C1O Executive Council, 40 L.R.R.M. (BNA) 84 (1957).

6. Formally known as the Labor-Management Reporting and Disclosure Act of 1959 (LMRDA), the Landrum-Griffin Act is codified at 29 U.S.C. $\$ \$ 401-531$ (1982 \& Snpp. V 1987). Referring to the then recently enacted LMRDA, the final report of the McClellan Committee stated that "Hoffa, more than any other single individnal, must bear the responsibility for specific provisions of the law that is now on the Nation's statute books." S. REP. No. 1139, 86th Cong., 2d Sess. pt. 3, at 731 (1960).

7. See D. Moldea, The Hoffa Wars 171-73, 185-86 (1978). For general accounts of Hoffa's controversial career, his investigation by the McClellan Committee, and his numerous prosecutions, see R. James \& E. James, supra note 2; C. Mollenhoff, Tentacles of Power: The StORY OF JiMmY HofFa (1965); W. SHERIDAN, The FALl aND Rise OF JiMmY Hoffa (1972); L. VeLIE, supra note 1. For Hoffa's side of the story, see J. HOFFA, HOFFA: THE REAL STORY (1975); J. Hoffa, THE TRIALS OF JiMMY HoFfa (1970).

8. See Serrin, Jackie Presser's Secret Lives Detailed in Government Files, N.Y. Times, Mar. 27, 1989, at 1 , col. 5 .

9. See D. MOLDEA, supra note 7 , at 71 .

10. See Serrin, supra note 8. 
engineered Presser's selection. ${ }^{11}$ Shortly after his own federal indictment for embezzling some $\$ 700,000$ from his home local in Cleveland, ${ }^{12}$ Presser won election as President in his own right by convention delegates selected through procedures violating the spirit, and arguably the letter, of the Landrum-Griffin Act. ${ }^{13}$

Nor do the parallels stop there. As the McClellan Committee had done a generation before, the President's Commission on Organized Crime recently identified the IBT as the national union "most controlled" by organized crime. ${ }^{14}$ In response, the federal government has again launched a campaign to clean up the union. In an action based on the civil provisions of the Racketeer Influenced and Corrupt Organizations Act (RICO), ${ }^{15}$ the Department of Justice sought to place the entire Teamsters union under the temporary control of a court appointed trustee. ${ }^{16}$ That hitigation resulted in a consent decree creating a remedy substantially more radical than the monitorship imposed during the Hoffa period. ${ }^{17}$

One major difference between the 1950s and 1980s, however, is the complete turnabout in stature that the IBT has experienced within the larger American labor movement. Unlike the 1950s, when the union was an outcast, the IBT's recent reaffiliation with the AFL-CIO inarks the end of a thirty-year exile and a return to the mamstream for the Teamsters, a development that raises serious questions about the nature of the AFL-CIO's commitment to eliminate corrupt elements froin its ranks. ${ }^{18}$

The vast majority of American unions, of course, are untamted by corruption or organized crime. ${ }^{19}$ But a little racketeering can go a long way. As the President's Commission on Organized Crime explained,

11. See Serrin, supra note 8; Lubasch, Ex-Teamster Chief Tells Jury Union is Controlled by Mafia, N.Y. Times, June 2, 1987, at 1, col. 3.

12. Shenon, Teamster Leader Is Indicted by U.S. for Racketeering, N.Y. Times, May 17, 1986, at $\mathrm{Al}$, col. 3. Presser never denied the underlying charge-authorizing payments to "ghost employees" associated with the mob who were on the union's payroll but never performed any work for the union-but he claimed to be acting with FBI approval while serving as an FBI informant. Presser died before he could be brought to trial, but two codefendants were convicted. Serrin, supra note 8 .

13. Serrin, Jubilant Teamsters Elect Presser as President, N.Y. Times, May 22, 1986, at A22, col. 1. For a discussion of the questionable legality of the procedure used to select Teamster convention delegates, see infra note 591.

14. President's Comm'n on Organized Crime, The Edge: Organized Crime, BusiNeSS, AND LABOR UNIONS 89 (1986) [hereinafter PRESIDENT'S COMMISSION].

15. 18 U.S.C. $\S \S 1961-1968$ (1982 \& Supp. V 1987).

16. See Complaint, United States v. International Bhd. of Teamsters, 88 Civ. 4486 (S.D.N.Y. June 29, 1988).

17. See infra text acconupanying notes 581-607.

18. See Noble, Teamster Return to AFL-CIO Wins Approval, N.Y. Times, Oct. 25, 1987, at 1, col. 5.

19. The federal government estiniates that 300 to 400 local unions, out of about 70,000 , are associated, influenced, or controlled by organized crime. PRESIDENT'S COMMISSION, supra note 14, 
"[M]any infiltrated unions are major locals embracing thousands of members, and they operate in strategic commercial sectors and large urban and metropohtan centers. Influence over these locals enables organized crime to dominate the international unions and acquire a foothold in the marketplace."20 Just as little lias changed in the Teamsters union, similar patterns of racketeering remain entrenched in several other major unions that the investigations of the 1950s exposed as corrupt, viz., the Hotel Employees \& Restaurant Employees Umon, the Laborers International, and the International Longshoremen's Association. ${ }^{21}$

For decades, then, the battle against organized crime's infiltration of important unions, like the Teamsters, has been a losing effort. There have been unany victories against individual racketeers, and over the years, hundreds of corrupt union officials have been jailed. But as often as not, successors cut froin the same cloth replaced deposed officials and continued the systematic exploitation of their urions' memberships. The nanies of the players sometimes change, but their game remains the same.

A drainatic new weapon has recently emerged on this legal battlefield, however, and it has the potential to tip the balance decidedly in favor of those seeking a permanent housecleaning of the Teamsters and other racketeer-ridden unions. Through the civil RICO structural injunction, courts can impose structural reforins and even trusteeships in order to clean up corrupt unions. In United States v. Local 560, International Brotherhood of Teamsters, ${ }^{22}$ for exainple, the Third Circuit upheld a RICO injunction that removed from office the entire executive board of a racketeer-controlled union local and replaced it with a court-appointed trustee until fair elections could be held. ${ }^{23}$ On a much larger scale, in the

at 8 n.2. An unknown number of additional unions suffer from corruption on a smaller and more "amateur" scale.

20. Id. at 2. But see D. ElbaOR \& L. Gold, The Criminalization of Union Activity: Federal Criminal ENForcement Against Unions, Union Officials and EMployees (1985) (arguing that federal law enforcement authorities have greatly exaggerated the extent of labor racketeering and have wastefully and discrimmatorily singled out the labor movement for investigation and proseeution).

21. President's Commission, supra note 14, at 33-88, 145-66; see also Hotel Employees \& Restaurant Employees International Union: Hearings Before the Perm. Subcomm. on Investigations of the Senate Comm. on Governmental Affairs, 97th Cong., 2d Sess. and 98th Cong., 1st \& 2d Sess. (1982-84) (investigation of organized crime influence on Hotel and Restaurant Employees Union) [hereinafter Hotel Employees]; Waterfront Corruption: Hearings Before the Perm. Subcomm. on Investigations of the Senate Comm. on Governmental Affairs, 97th Cong., 1st Sess. (1981) (inquiry into extensive organized crime influence on umions operating in east and gulf coast ports) [hereinafter Waterfront Corruption]; S. REP. No. 595, 98th Cong., 2d Sess. (1984); Barnes \& Windrem, Six Ways to Take Over a Union, MOTHER JONES, Aug. 1980, at 34 (describing corruption in the Laborers).

22. 780 F.2d 267, 270 (3d Cir. 1985), cert. denied, 476 U.S. 1140 (1986).

23. See infra text accoinpanying notes $364-424$. 
most ambitious union clean-up campaign ever attempted, the Justice Department has recently obtained a RICO remedy against the entire 1.6 million member Teamsters International. ${ }^{24}$

These RICO remedies are controversial experiments in institutional reform litigation in the context of labor unions; they represent an attempt to use civil litigation to clean up corrupt unions by relying on the courts' active, extensive, and ongoing oversight, intervention, or direct control over internal union affairs until such time as the desired reforms are in place. Institutional reform litigation, well known in such contexts as school desegregation and the reform of prisons and mental institutions, ${ }^{25}$ lias until recently been rarely attempted in the labor noveinent.

This Article examines the current trend toward institutional reform litigation within unions and evaluates its propriety, legal foundation, and prospects for success. This requires an understanding of the problems urion reform litigation is intended to redress, and the alternative approaches such litigation supplenients or replaces. To gain this understanding, the Article begins with an overview of the nature and extent of corruption within the labor novement, and proceeds to a discussion of the less drastic alternatives that niust be pursued before institutional reform litigation slould conmence. The Article next examines the con1mon law and statutory precedents for the judicially supervised reform of labor unions; this leads to an exploration of the civil RICO structural injunction and its relation to botli federal labor policy and the associational rights of unions and their inembers. The Article then evaluates the leading exanıples of umion reform litigation over the years, with a particular focus on the Teamsters Board of Monitors from the Hoffa period, the inore recent RICO trusteeship over Teanisters Local 560, and the RICO reforms recently imposed on the Teansters International. Finally, in the form of proposed civil RICO "sentencing" guidelines, the Article suggests means to develop remedies in union reform litigation that will tend to maximize their effectiveness but, at the saine time, minimize their intrusiveness.

24. See infra text accompanying note 573-609.

25. See generally Chayes, The Role of the Judge in Public Law Litigation, 89 Harv. L. REv. 1281 (1970) (describing and analyzing the differences between public law litigation and traditional, bipolar lawsuits between private parties); Fiss, The Supreme Court, 1978 Term-Forward: The Forms of Justice, 93 HARV. L. REV. 1 (1979) (describing structural reform litigation as vehicle for giving meaning to constitutional values in the operation of large-scale organizations); Horowitz, Decreeing Organizational Change: Judicial Supervision of Public Institutions, 1983 Duke L.J. 1265 (tracing the origins, characteristics, and consequences of organizational change decrees). 


\section{The Nature AND Scope OF UNION CORRUPtion AND LABOR RACKETEERING}

During 1981, Tony Provenzano collected an officer's salary of $\$ 28,000$ from his Teamsters Local 560 in Union City, New Jersey. In amount, Provenzano's salary was quite reasonable. ${ }^{26}$ Less reasonable was the fact that when he collected it, Provenzano was three years into the life sentence he was serving for ordering the murder of a political rival within his local. ${ }^{27}$ While umion corruption and labor racketeering can take many foruns, it seldom appears in all foruns within a smgle local. Unfortunately, Local 560 had it all.

Labor racketeering is "the use of union office or power for personal profit."28 One of the nuost obvious abuses of union power is for officers simply to siphon money from their union treasuries. The $\$ 28,000$ payment to Provenzano was only the tip of the iceberg in Local 560. Provenzano had received similar payments in 1979 and $1980,{ }^{29}$ and during an earlier period, again while holding no umion office (and, in fact,

26. Tony's brother Salvatore Provenzano, on the other hand, who took over the leadership of Local 560 after Tony was jailed in 1978, earned more than $\$ 230,000$ in Teamster salaries during 1982, a year in which Jackie Presser earned over \$350,000. Both men held multiple "full-time" Teamster offices at the local, regional, and national levels. See It's A Family Affair: Nine Families Pocket \$3.5 Million, Convoy Dispatch, Sept. 1982, at 4 (Convoy Dispatch is the monthly newspaper of Teamsters for a Deinocratic Uuion (TDU)). During 1987, as multiple job holding remained a cominon practice among Teamster officials, salaries of $\$ 100,000$ or more were paid to 124 Teamster officials-more than all other American unions combined. The salaries of these 124 officers totalled alinost $\$ 19$ million. Jackie Presser led the way with total compensation of over $\$ 600,000$. See Shameful Squandering of Our Union's Resources, ConvoY DisPaTch, Oct. 1988, at 6-7. In addition to these large, multiple salaries, Teamster officials usually receive correspondingly generous pension coverage through multiple Teamster pension plans. See How Locals Inflate Officers' Pensions, CoNvoY DisPatch, April 1987, at 12.

27. Teamsters Local 560 Paid $\$ 28,143$ in '81 To Jailed Ex-Chief, Wall St. J., July 28, 1982, at 2, col. 3. Provenzano, who recently died, was serving his sentence at the federal prison in Loinpoc, California. He was convicted in 1978 for ordering the 1961 slaying of Anthony Castellitto, a popular Ineinber of Local 560 whom Provenzano considered a threat to his continued control over the union. See United States v. Local 560, Int'l Bhd. of Teamsters (Local 560 III), 780 F.2d 267, 273 (3d Cir. 1985), cert. denied, 476 U.S. 1140 (1986). Another dissident member of Local 560, Walter Glockner, was inurdered in 1963 on the morning after he expressed opposition to Provenzano during a union meeting. Although one eyewitness later identified the murderer as Thomas Reynolds, a Local 560 official and a Provenzano relative by marriage, no one was ever convicted for the crime. See United States v. Local 560, Int'1 Bhd. of Teamsters (Local 560 I), 581 F. Supp. 279, 308 (D.N.J. 1984), aff'd, 780 F.2d 267, cert. denied, 476 U.S. 1140 (1986).

28. P. TAFT, CoRruption AND RACKetEering in the LABOR MOVEMENT 1 (2d ed. 1979). See also PresidenT's CoMmission, supra note 14, at 9 (defining labor racketeering as "the infiltration, doinination, and use of a union for personal benefit by illegal, violent, and fraudulent means"). In this Article, the terms labor racketeering and union corruption will be used interchangeably.

29. Local 560 III, 780 F.2d at 287. It is unclear whether these payments in fact constituted salary payınents, as opposed to deferred salary or a pension bonus, but there is no question that the payments were not "in the best interests of Local 560 or its membership, but rather . . were solely for the personal benefit of Anthony Provenzano." Id. at 288. 
while disqualified froin holding office due to prior labor racketeering convictions), ${ }^{30}$ he illegally received almost $\$ 200,000$ in payments from his local. . $^{31}$

Stealing the membership's dues, of course, is an old fashioned, rather crude form of union corruption, and ainbitious racketeers often search for deeper pockets to pick: the employers. As one commentator observed, "The firm is the efficient side of racketeering activity. . . . It should be quite clear that the expropriation can never be as high from workers as from employers." 32

Labor racketeering directed at employers usually takes two related forms: "strike insurance" and "sweetheart" contracts. In both cases, the corrupt union leader accepts under-the-table payoffs in return for compromising the membership's interests in organizing, bargaining with nianagement, or enforcing a contract. ${ }^{33}$ The two forms of corruption differ $\mathrm{m}$ that whereas strike nisurance is forced upon unwilling employers as a variation of the old protection racket, sweetheart deals are often welcomed and initiated by corrupt eniployers who benefit froin such arrangements as much as the union officials. A $\$ 10,000$ payoff to a corrupt union official, for example, might result in a sweetheart contract saving the employer $\$ 100,000$ in labor costs. The union official and the employer come out ahead; the losers are the workers and the einployer's more honest competitors. ${ }^{34}$ Sweetheart deals also victimize the labor

30. Until its amendment in 1984, section 504 of the Landrum-Griffin Act, 29 U.S.C. § 504(a) (1982 \& Supp. $V$ 1987), barred individuals convicted of certain crimes froin holding union office for five years following their convictions or the ends of their prison terms. The 1984 amendment, part of the Comprehensive Crime Control Act of 1984, Pub. L. No. 98-473, 98 Stat. 1837 (codified as amended at 29 U.S.C. $\S 504$ (a) (1982 \& Supp. V 1987)) increased the maximum period of debarment to thirteen years.

31. See Local 560 III, 780 F.2d at 286-88.

32. Weinstein, Racketeering and Labor: An Economic Analysis, 19 INDUS. \& LAB. REL. REV. $402,406,412$ (1966).

33. See generally President's Commission, supra note 14, at 16-27. With limited exceptions, section 302 of the Labor Management Relations Act, 29 U.S.C. $§ 186$ (1982 \& Supp. V 1987), outlaws payments from employers to unions or union officials.

Illegal payoffs can take many imaginative forms: "No longer is cash received in a booth of a hotel bar. Today, with various degrees of expertise, payments are camouflaged among the countless checkbook transactions of the victim's business." Blakey \& Goldstock, "On the Waterfront": RICO and Labor Racketeering. 17 AM. CRIM. L. REV. 341, 345 (1980). A common technique is to put the corrupt umion official or his "bag man" on the employer's payroll as a "ghost" employee who receives a paycheck without ever showing up for work. See, e.g., United States v. Pecora, 798 F.2d $614,617-21$ (3d Cir. 1986) (general manager of company kept union business agent on payroll for a decade to influence conduct of union business); United States v. LeRoy, 687 F.2d 610, 613-16 (2d Cir. 1982) (vice-president of union local placed on the payroll of seven subcontractors and received compensation without performing any work), cert. denied, 459 U.S. 1174 (1983).

34. Collusive relations between corrupt unions and corrupt employers can become vehicles for "stabilizing" Inarket conditions in highly competitive industries and indeed for eliminating soine competitors altogether. See New York State Organized Crime TASK Force, Corruption 
movement more generally by reducing wages and worsening working conditions; by presenting the public image of a labor movement plagued by corruption and ridden with racketeers; and by functioning as legal bars to the efforts of honest unions to win from corrupt ones the right to represent the victimized workers. ${ }^{35}$

Payoffs from employers were everyday events in Tony Provenzano's Local 560. Consider only those payoffs for which Provenzano or his associates were convicted: payments for "labor peace" from the Dorn Transportation Company between 1952 and 1959; attempted extortion of "labor peace" payoffs from the Braun Company in 1961; payments from Seatrain Lines and its in-lrouse trucking companies between 1969 and 1977, which allowed them to avoid umionization and to pay Local 560 members low wages and no benefits; and payments from four trucking companies between 1971 and 1980, which allowed the trucking companies to avoid contractual obligations to hire Local 560 "city men" upon entering the local's jurisdiction. ${ }^{36}$

Collectively bargained pension and health and welfare funds ${ }^{37}$ provide labor racketeers with another pot of money througlı which "tlie savings of working men and women are pilfered, embezzled, parlayed, mismanaged and outright stolen."38 One form of pension fund abuse common in Local 560 was the receipt of kickbacks for arranging questionable pension fund loans. ${ }^{39}$ Another was the accrual of unreasonably high administrative costs by, for example, retaining an unscrupulous

AND RACKeteERING IN THE NeW YoRK CITY CONSTRUCTION INDUSTRY 42-66 (Interim Report 1988) [hereinafter N.Y. TASK ForCE]; PRESIDENT's Commission, supra note 14, at 10-11; Weinstein, supra note 32 , at $406-08$. Thus, it is not surprising that in none of the highly competitive industries susceptible to these forms of labor racketeering, such as construction, trucking, and the waterfront, "is there a public record of substantial employer opposition to the works of the corrupt in the labor-management field." J. HUTCHINSON, THE IMPERFECT UNION: A HISTORY OF CORRUPTION IN AMERICAN TRADE UNIONS 383-84 (1970).

35. The National Labor Relations Board's "contract bar rule" prevents workers covered by a collective bargaining agreement from replacing their union with a different one for the life of the contract or three years, whichever period is shorter. See 1 THE Developing LABOR LAW 361-63 (C. Morris ed. 1983). Colorfully put, "Labor law is thus sometimes more effective than an army of professional sluggers." Blakey \& Goldstock, supra note 33, at 344.

36. See United States v. Provenzano, 620 F.2d 985 (3d Cir. 1980); United States v. Local 560, Int'1 Bhd. of Teamsters (Local 560 I), 581 F. Supp. 279, 289-90 (D.N.J. 1984) aff'd, 780 F.2d 267 (3d Cir. 1985), cert. denied, 476 U.S. 1140 (1986).

37. These funds now have assets totalling more than $\$ 51$ billion. President's CoMmission, supra note 14 , at 13 .

38. Thornton v. Evans, 692 F.2d 1064, 1065 (7th Cir. 1982).

39. In 1974 and 1977, for example, Tony Provenzano received kickbacks totalling more than $\$ 60,000$ in connection with Local 560 pension and welfare fund loans to a Florida real estate developer. See Local 560 III, 780 F.2d at 274, 293 n.33. Provenzano was also convicted in 1978 for violating anti-kickback laws relating to a proposed loan from a Teamsters benefit fund in Utica, New York. See Local 560 I, 581 F. Supp. at 290. 
fund accountant even after his indictment for systematically overbilling the fund. 40

Pension fund abuse proves to be a particularly pernicious form of labor racketeering because its effects on plan participants may remain hidden for years. Such effects may take two forms. First, financial losses to the fund may cause recipients' benefits to decrease or to increase at a slower pace than they otherwise would; in extreme cases, the fund may become imsolvent altogether. Second, and inore subtlely, the losses resulting from fund mismanagement may create an imcentive for plan administrators trying to hide those losses to tighten eligibility requirements. As a result, fewer plan participants qualify for benefits, and those that do qualify receive smaller benefits than expected. ${ }^{41}$ When the union member finally feels the effect-for example, when a worker about to retire learns that she is eligible for only half the expected pension because of a short interruption in employment years before-it may be too late either to remedy the abuses or to make alternative financial arrangements for retirement. ${ }^{42}$

Umion corruption also can facilitate other illicit activities, such as gambling, loansharking, and pilferage. ${ }^{43}$ Local 560 scores at least two out of three here, with members of the Provenzano group having been convicted of both loansharking and theft of property from employers' loading docks. ${ }^{44}$

Finally, extensive union corruption usually leads to economic or physical retaliation directed at union members who are bold enough to challenge their corrupt officers' conduct or continued tenure in office. ${ }^{45}$ During the early 1960s, the Provenzano group consolidated its control over Local 560 by murdering two union rivals. ${ }^{46}$ In the ensuing years, the high level of intimidation in the local virtually precluded any further

40. Local 560 III, 780 F.2d at 271. Similarly, a fund administrator was retained in spite of the fact that he had taken payoffs from an insurance company representative during the 1950s. Id.

41. It may be no coincidence that when ERISA recently was amended to reduce the period needed for pension benefits to "vest" from ten years to five for most plans, Tax Reform Act of 1986, Pub. L. No. 99-514, § 1113, 100 Stat. 2085, 2446-48, 26 U.S.C. 411(a)(2) (1982 \& Supp. V 1987), Teamsters lobbyists made no attempt to block successful industry efforts to exclude from the amendment's coverage multi-employer pension plans typical of those covering most Teamsters. 26 U.S.C. $\S 411$ (e) (1982 \& Supp. V. 1987); see Teamsters Cut Out of New Pension Law, Convoy Dispatch, Sept. 1986, at 8.

42. The effects of pension and welfare fund abuse may be felt more quickly if, instead of cutting or slowing the growth of benefits or tightening eligibility requirements, the union seeks larger benefit fund contributions from employers at the bargaining table. In such cases, fund abuse results in cuts or redueed rates of growth in the employees' take-home pay.

43. See Weinstem, supra note 32 , at $403,411-12$.

44. See Local 560 I, 581 F. Supp. at 290-91.

45. See President's Commission, supra note 14, at 114.

46. See supra note 27. 
rank-and-file opposition to the outrageous conduct of Provenzano and his associates. ${ }^{47}$

Local 560, of course, has no monopoly on corruption, and neither does the Teamsters International. Occasionally, even a United Auto Workers official gets caught with his hand in the till, ${ }^{48}$ and sweetheart contracts and strike insurance rackets are rainpant throughout the construction industry and on the docks. ${ }^{49}$ Similarly, other unions besides the Teanisters, such as the Hotel and Restaurant Einployees and the Laborers International, have well-deserved reputations for pension and benefit fund abuse.50 Finally, dozens of union locals in the construction trades have permitted their hiring halls to dispatch workers to jobs on the basis of such illegitimate factors as race and sex discrimination, ${ }^{51}$ cronyism, ${ }^{52}$ and under-the-table payoffs. ${ }^{53}$

Of course, none of this is new. The problem of union corruption has plagued some segments of the labor inoveinent almost since its niception. ${ }^{54}$ Over the years, a number of interesting patterns have emerged. For example, corruption is generally niore of a problein in the older, craft unions of the pre-nierger AFL than in the newer, industrial umions organized by the CIO during the 1930s. ${ }^{55}$ Some commentators have suggested that the conservative "busmess unionisin" typical of the AFL was

47. See Local 560 III, 780 F.2d at 278 .

48. See, e.g., United States v. Stockton, 788 F.2d 210, 220 (4th Cir. 1986) (affirming local president's conviction for embezzhing union assets).

49. See, e.g., N.Y. TASK FoRCE, supra note 34 (cataloguing corruption and racketering that plagues New York City's construction industry); President's CoMMIssion, supra note 14, at 3370, 217-26 (documenting extensive racketeering in New York, New Jersey, and Miami); Waterfront Corruption, supra note 21 (investigation of influence and control organized crime exercises over unions in a number of east and gulf coast ports).

50. See, e.g., Barnes \& Windrem, supra note 21, at 40-41; Hotel Employees, supra note 21; PREsident's COMMISsion, supra note 14, at 78-79, 152-62; P. TAFT, supra note 28 , at 65 . There is no question, however, that the Teamsters have been in a class by themselves when it comes to pension and welfare fund racketeering. Abuses of the Teamsters' giant Central States fund are well documented, see infra text accompanying notes 214-36, and from 1974 through 1981, former IBT President Roy Williams himself took bribes of $\$ 1500$ per month in exchange for arranging pension fund loans for Las Vegas casinos. See Trott, Recent Developments in Criminal Labor Law, 37 LAB. L.J. 131, 132 (1986). The late IBT President Jackie Presser also had a long history of questionable self-dealing in connection with Teamster funds. In the early 1960 s, for exainple, he borrowed over $\$ 1$ million from the Central States fund, only to default on the loan several years later.

51. See infra notes $185-86$ and accompanying text.

52. See infra text accompanying note 472 .

53. See infra text accompanying note 460 .

54. The best history of union corruption is J. HuTchinson, supra note 34; see also M. JoHNson, Crime on the Labor Front (1950); H. Seidman, Labor Czars: A History of Labor RACKETEERING (1938); P. TAFT, supra note 28, at 5-17, 45-70.

55. Compare, for example, the extensive corruption reported in such old AFL unions as the Teamsters, the International Longshoreman's Association, and building trades unions such as the Laborers, Operating Engineers, and Boilermakers, with the small amount of corruption found in 
simply more susceptible to abuse than the more idealistic, politically progressive "social unionisn!" of the CIO. ${ }^{56}$

Other explanations focus on the comnion characteristics of the construction, garment, longshore, service, and trucking industries, where labor racketeering is most prevalent:

All of these industries are notable in soine degree for small business units, high proportional labor costs, small profit margins, intensive competition, and a considerable rate of business failures. At least in the past the battle for survival was severe, with ethics an early casualty. Wages were a natural point of attack by employers who, alone or in concert, sought cheapness and stability by whatever ineans were available-coercion, bribery, or collaboration. Union officials used their economic power to private advantage against employers especially vulnerable to the strike. ${ }^{57}$

The relatively sniall scale corruption of amateur crooks-the "trade unionists with a flaw" that probably can be found in any union-should be distinguished from the more extensive operations of professional labor racketeers - "the proconsuls of the American underworld" who have had their greatest success infiltrating such unions as the Teamsters, Laborers, Hotel and Restaurant Employees, and east coast Longshoremen. ${ }^{58}$ The often chaotic conditions in the industries served by these unions can create tempting opportunities for "the professional and violent stabilizer." 59

such CIO unions as the Steelworkers and the United Auto Workers. See P. TAFT, supra note 28, at 1-37.

56. See, e.g., J. Hutchinson, supra note 34, at 371 ("Business unionism is not a mercenary creed, but neither is it much of a discipline. ... [T] [Te commodity conception of trade unionism is a poor guide to ethics; the narrowness of its vision leaves too much to the imagination of the acquisitive and the weak."). But see P. TAFT, supra note 28, at 20-28 (arguing against Hutchinson's explanation).

57. J. HuTCHINSON, supra note 34 , at 380 . Hutchinson continued:

In contrast, the circumstances of the mass production industries have always been a hindrance to trade union corruption. These industries are large, highly centralized, stable, not savagely competitive, very much in the public eye, too big for the racketeers. The mass production unions . . . are typically organized into substantial locals; their members are grouped together in large numbers and close contact, better equipped to watch over the affairs of the union and to resist intimidation.

Id. at 381. See also N.Y. TASK FoRCE, supra note 34, at 42-66.

58. J. Hutchinson, supra note 34 , at 382 .

59. Id. at 380. In the restaurant and trucking industries, organized crime has been an active force since its bootlegging activities during Prohibition. Indeed, the repeal of Prohibition was a major force in organized crime's infiltration of the labor movement. It cut off one of organized crime's largest sources of income and necessitated a search for new income. "Trade unions were an obvious target." Weinstein, supra note 32, at 403. In some industries, gangsters were actually invited in by labor leaders who needed the muscle that gangsters could provide in their battles with company goons or rival factions, and once in, the criminal elements tended to stay in. See J. HuTChINSON, supra note 34 , at 74-92. 
Although certain segments of the labor movement suffer from corruption and the infiltration of organized crime, the entire labor movement is certainly no worse im this regard than other segments of society. ${ }^{60}$ Indeed, employers often set the tone for labor racketeering. Consider the construction industry, for example:

Certainly the desire to eliminate competitive bidding initially must have come from the employer; and employers accustomed to giving kickbacks and rebates, to paying inspectors for systematically violating building codes ... . are not going to be reluctant to use the same methods in their labor relations. Where systematized racketeering exists, it will usually be found einbodied in the entire system of carrying on a business or industry. ${ }^{61}$

But labor racketeering deserves our attention for reasons beyond consideration of its anticompetitive impact on the economy. ${ }^{62}$ Simce federal law is a major source of union power, ${ }^{63}$ the public has a strong interest in a clean labor movement and in democratic uniomism. ${ }^{64}$ At their best, umions use that power to bring to the workplace not only improved wages and working conditions but also a level of industrial democracy and human digmity that is impossible to measure in dollars and cents.

60. For an argument that the extent of union corruption and labor racketeering has been greatly exaggerated, seẹ D. ElBAOR \& L. GolD, supra note 20, at 2, 40-43 .

61. P. TAFT, supra note 28 , at 33.

62. See N.Y. TASK Force, supra note 34; PrEsident's CoMmission, supra note 14; Reuter, Racketeers as Cartel Organizers, in The Politics AND ECONOMICs of ORGaNized CRIME (H. Alexander \& G. Caiden eds. 1985).

63. For example, subseetion 9(a) of the National Labor Relations Act, 29 U.S.C. § 159(a) (1982), gives umions selected by a majority of the workers in a bargaining unit the exclusive authority to represent all those workers in collective bargaining.

64. The relationship betwecn autocratic unionism and corrupt unionism was recognized by Congress when it passed the Labor-Management Reporting and Disclosure Act of 1959. As Senator McClellan stated during the debates over the Act:

I do not beheve that racketeering, corruption, abue [sic] of power, and other improper practices on the part of some labor organizations can be, or ever will be, prevented until and unless the Congress of the Umited States has the wisdom and the courage to enact laws prescribing mimimum standards of democratic process ... for the admimistration of internal union affairs.

105 CONG. REC. 6471 (1959), reprinted in 2 NLRB, LEgISLATIVE HISTORY OF THE LABOR-MANAGEMENT REPORTING AND DisCLOSURE ACT OF 1959, at 1098 (1959) [heremafter LMRDA LEGISLATIVE HISTORY].

At one time commentators attempting to minimize the connection between autocracy and corruption could point to the absence of corruption during John L. Lewis's autocratic reigu as president of the United Mine Workers. See J. HuTchinson, supra note 34, at 373; P. TAFT, supra note 28, at 29-30. That example now fails, however, since the UMW under Lewis' successor, Tony Boyle, was exposed as suffering from terrible corruption. Indeed, Boyle was eventually convicted of ordering the brutal murders of reform candidate Jock Yablonski and his family in a futile effort to maintain his hold on the UMW. For accounts of Boyle's role in Yablonski's murder, see J. FINLEY, THE CORRuPT KINGDOM: THE RISE AND FALl of THE UNITED Mine Workers 255-79 (1972); $B$. Hume, Death and the Mines: Rebellion and Murder in the United Mine Workers 240-59 (1971). 
Equally important, unions provide a vital, collective voice for workers in the political arena. ${ }^{65}$ These functions of unionism are incompatible with labor racketeering, and a labor movement plagued with corruption is one which the public may not tolerate indefinitely. ${ }^{66}$

\section{Keeping Its Own House Clean: The Labor Movement's INTERNAL REMEDIES}

The frustrations of trying to win a seemingly endless legal war against labor racketeering liave generated an infatuation with RICO trusteeships in law enforcement circles. But even their strongest proponents agree that RICO trusteeships should be used only as a last resort. This view is in keeping with a central tenet of federal labor policy: unions and their members should have anple opportunities to resolve their problems internally before the courts interfere. ${ }^{67}$ The justifications for this policy are threefold: first, to prevent unnecessary governmental interference with the affairs of private organizations; second, to promote responsible union self-government by providing umon officials of higher authority the opportumity to oversee, and where necessary to correct, the conduct of lower level umion officials; and finally, to conserve judicial resources, since disputes resolved internally need not be brought to

65. See Goldberg, Book Review, 84 MICH. L. REv. 1063, 1077-78 (1986) (reviewing R. FrEEman \& J. Medoff, What Do Unions Do? (1984)); Hartley, The Framework of Democracy in Union Government, 32 CATH. U.L. REv. 13, 54-61 (1982).

66. Cf. Summers, The Public Interest in Union Democracy, 53 Nw. U.L. REv. 610 (1958).

67. See, e.g., Clayton v. UAW, 451 U.S. 679, 696 (1981) (plaintiff in hybrid duty of fair representation/section 301 action must exhaust iuternal union remedies where such remedies can result in reactivation of plaintiff's grievance or the award of complete relief); Landrum-Griffin Act $\S 101(a)(4), 29$ U.S.C. $\S 411$ (a)(4) (1982) (authorizing courts to require union members to exhaust internal union remedies for up to four months before bringing suit against their unions); id. § 402(a)(1), (2), 29 U.S.C. § 482(a)(1), (2) (1982) (requiring union members to exhaust internal union remedies for up to three months before secking relief through the Department of Labor for violations of the fair election provisions of the Landrum-Griffin Act); id. $\S 501(b), 29$ U.S.C. $\S 501(b)$ (1982) (requiring uniou members to request their officers to take appropriate steps to remedy officer breaches of fiduciary duties before seeking such relief in the courts); $c f$. Republic Stecl Corp. v. Maddox, 379 U.S. 650, 659 (1965) (employee alleging a breach of a collective bargaining agreement must exhaust contractual remedies before bringing suit under section 301 of Labor-Management Relations Act, 29 U.S.C. § 185).

However, exhaustion requirements are not universally imposed and are subject to a number of important exceptions where they are present. See, e.g., NLRB v. Marine and Shipbuilding Workers Local 22, 391 U.S. 418, 428 (1968) (exhaustion of internal union remedies not required before union can be charged with unfair labor practice); Semancik v. United Mine Workers, 466 F.2d 144, 150-51 (3d Cir. 1972) (exhaustion requirements can be waived to avoid irreparable harm to plaintiffs or where exhaustion would be futile because the appeals structure is inadequate, or controlled by those to whom plaintiffs are opposed); $c f$. Fox \& Sonenthal, Section 301 and the Exhaustion of Intra-Union Appeals: A Misbegotten Marriage, 128 U. PA. L. REv. 989, 1034-35 (1980) (arguing against strict exhanstion requirements in duty of fair representation litigation). 
court. ${ }^{68}$ Before focusing on structural remedies such as trusteeships, therefore, an examination of the nature and effectiveness of the labor movement's own remedies for umion corruption is appropriate. 69

\section{A. Discipline of Corrupt Officers and Members and Damage Actions for the Recovery of Embezzled Union Funds}

Once corruption is detected, the umion itself, if its officers and membership are willing, can remedy isolated or small scale imstances of corruption.70 For example, a union can bring charges of violating the union's constitution agamst an official who embezzles from the umion treasury. If a union tribunal finds the official guilty, it can remove her froin office and suspend or expel her from the union's membership. ${ }^{71}$

68. See, e.g., Falsetti v. Local 2026, United Mine Workers, 400 Pa. 145, 161 A.2d 882 (1960); S. REP. No. 187, 86th Cong., 1st Sess. 7 (1959), reprinted in LMRDA LEGISLATIVE HISTORY, supra note 64, at 397, 403; Vorenberg, Exhaustion of Intraunion Remedies, 2 LAB. L.J. 487 (1951). An earlier rationale for exhaustion was that union constitutions containing such requirements were contractually binding on the unions' meinbers. See, e.g., Wilson v. Miller, 194 Tenn. 390, 396, 250 S.W.2d 575, 577 (1952). However, like contracts of adhesion, such agreements are not always enforceable.

69. To understand the operation of internal union renedies, one inust have some knowledge of the three-part structure into which most of the labor moveinent fits. At the bottom is the local union, typically representing the workers in a single workplace or in a number of similar workplaces in one city or region. The vast majority of union locals are chartered by and are essentially subdivisions of a parent union organized on a national basis. These national unions, or "Interuationals" as they are often called when they include locals in Canada, conprise the second major component of the labor movement. National unions often exercise extensive coutrol over the structure, activities, and even the very existence of their affihated locals. Finally, most national unions, with some important exceptions, are affiliated with the American Federation of Labor and Congress of Industrial Organizations. The AFL-CIO is a loose, voluntary federation; each menber national union remains an autonomous organization in control of its own affairs. See generally M. ESTEY, THE UNIONS: StRucture, Development AND MANAGEMENT 43-54 (3d ed. 1981); J. Wallihan, Union GovERNMENT AND ORGANIZATION 86-175 (1985).

70. Of course, detecting the corruption in the first place may not be easy. Sone assistance to the rank-and-file is provided by title II of the Landrum-Griffin Act, which requires labor organizations, and some union offieers, employees, and enployers to file annual financial reports with the Departnent of Labor. Landrum-Griffin Act $\S \S 201-03,29$ U.S.C $\$ \$ 431-433$ (1982). These reports are available to the public, id. $\S 205,29$ U.S.C. $\S 435$ (1982), and for just cause, a union member is entitled to inspect the union's books, records, and accounts in order to verify the union's financial reports. Id. $\$ 201$ (c), 29 U.S.C. $\S 431$ (c) 1982. The standard for determining just cause for such an examination of the union's books is minimal, and mentbers who successfully sue to enforce their right of inspection are entitled to attorneys' fees. Mallick v. International Bhd. of Elec. Workers, 749 F.2d 771 (D.C. Cir. 1984).

71. Any labor organiztion's procedures and grounds for disciplining union officers or nembers must be spelled out in the organization's constitution or bylaws, Landruin Griffin Act $\S 201(\mathrm{a})(5)(\mathrm{H})(\mathrm{I}), 29$ U.S.C. $\S 431(\mathrm{a})(5)(\mathrm{H})(\mathrm{I})(1982)$, and disciplinary proceedings (other than, in soine cases, removing an officer from his or her post) must coinply with the safeguards against inproper disciplinary action contained in section 101(a)(5) of the Act, 29 U.S.C. $\S 411(a)(5)$ (1982). See generally M. MaLin, Individual Rights Within the Union 92-106 (1988) (collecting cases defining section 101(a)(5)'s scope). The sometines more limited protections afforded to union officers were addressed by the Suprene Court in Shcet Metal Workers Int'l. v. Lynn, 109 S.Ct. 639, 
The union also can use its disciplinary proceedings to obtain restitution of the embezzled funds by imposing a fine on the guilty party equal to the amount stolen. ${ }^{72}$

Alternatively, a union might seek damages from corrupt officers through a common law tort action or, in appropriate cases, treble damages and attorneys' fees through the civil provisions of the RICO statute. $^{73}$ These court actions are particularly appropriate when union officials have taken payoffs from corrupt employers, because the employers mvolved are equally guilty and also should be held accountable. However, determining an appropriate measure of damages in such cases can be complicated. A natural starting point would be the dollar amount of the illegal payoffs, since that sum represents the cost to the einployer of buying off union representation that properly belonged to the union's meinbership. But simce payoffs typically cost employers less than an honest labor relations policy would (why else make the payoffs?), actual losses to the union, im terms of a reduced reputation for effectiveness, and to the union's membership, in terms of lost grievances and sinaller wage and benefit packages, generally exceed the payoffs. Therefore, that starting figure should be subject to a reasonable inultiplier appropriate to the facts of any given case.

In situations in which union officials refuse to authorize such lawsuits against their corrupt colleagues, union members can mitiate the litigation themselves, on their union's behalf, in the union equivalent of shareholder derivative actions, pursuant to title $\mathrm{V}$ of the Landrum-Griffin Act. ${ }^{74}$ Whether a treble damages claim under civil RICO can be piggybacked onto a title $\mathrm{V}$ action against a umion officer for breach of his fiduciary duties is as yet unanswered. The doctrine of in pari materia, that two statutes addressing a common problem should be interpreted in

645 (1989) (elected local union officials may not be discharged by international for exercising free speech rights), and Finnegan v. Leu, 456 U.S. 431 (1982) (union officers appointed by previous president may be discharged by newly-elected president). See generally Levy, Legal Responses to Rank-and-File Dissent: Restrictions on Union Officer Autonomy, 30 Buffalo L. REv. 663 (1981); Pope, Free Speech Rights of Union Officers Under the Labor-Management Reporting and Disclosure Act, 18 HARV. C.R.-C.L. L. REv. 525 (1983).

In addition to the statutory remedies provided by Landrum-Griffin, improperly disciplined union members or officers can also resort to common law remedies, which the Act does not preempt. Landrum Griffin Act $\S \S 103,603($ a), 29 U.S.C. $\S \S 413,523($ a) (1982). For a study of sueh remedies, see Summers, The Law of Union Discipline: What the Courts Do In Fact, 70 YALE L.J. 175, 222-23 (1960).

72. If necessary, collection of such fines can be compelled through a common law contract action, since the union's constitution comprises a contract between the union and the offending member. See NLRB v. Boeing Co., 412 U.S. 67, 75-76 (1973).

73. See infra text accoinpanying notes $246-56$.

74. §501(b), 29 U.S.C. \& 501(b) (1982). See generally M. MALIN, supra note 71, at 315-27 (describing procedures for filing section 501(b) action). 
a manner that furthers the effectiveness of both, ${ }^{75}$ suggests that courts should recognize such a "hybrid RICO/section 501 action."76

\section{B. Voting the Rascals Out}

When members of the public hear tales about Teamsters leaders such as Jimmy Hoffa, Jackie Presser, and Tony Provenzano, they often ask why the members don't simply vote the rascals out. After all, that is just what rank-and-file miners did to the corrupt Tony Boyle regime in the United Mine Workers (UMW) seventeen years ago. ${ }^{77}$ The failure of the membership to take such action in the Teamsters, Laborers, and other umons is sometimes viewed as a sign that the rank-and-file like things just the way they are in their umons, corruption and all.

At times, that assumption may hold a gram of truth. Hoffa, for example, participated in the looting of union treasuries and pension funds, but he was also a genuinely effective and charismatic labor leader who dehivered substantially improved wages, benefits, and working conditions to the bulk of his membership. ${ }^{78}$ Jackie Presser, on the other hand, presided over a shrinking union membership with diminishing wages and deteriorating working conditions, ${ }^{79}$ and his difficulty in obtaining rank-and-file approval of the contracts he negotiated suggests that he probably would not have fared as well as Hoffa in a membership referendum. ${ }^{80}$

Unfortunately, we will never know, for the Teamsters' membership has never had a chance to vote for Hoffa or for any of the men who succeeded him-Frank Fitzsiminons, Roy Williams, Jackie Presser, or William McCarthy. Instead, convention delegates-1nost of whom are already part of the union power structure-elect the national officers of the Teamsters and many other national urions. Entrenched national administrations can mampulate some of these electoral systems, like the

75. See R. Dickerson, The INTER pretation and Application of STATUTES 233 (1975).

76. See infra text accompanying notes 333-37.

77. See P. Clark, The Miners' Fight for Democracy 25-31 (1981).

78. See Raskin, Why They Cheer For Hoffa, N.Y. Times Nov. 9, 1958 (Magazine). For discussions of Hoffa's effectiveness at the bargaining table, see R. JAMES \& E. JAMES, supra note 2, at 14394; Sloane, Collective Bargaining in Trucking: Prelude to a National Contract, 19 Indus. \& LAB. REL. REv. 21 (1965).

79. Under Presser's leadership, the Tearnsters pioneered the use of unpopular "two-tiered" contracts and granted wage concessions to even the most profitable of Teamster employers, such as the United Parcel Service. See, e.g., Master, Teamsters President Proposes Cut-Rate Pay for Recalled Workers and New Hires, LABOR NoTEs, July 1983, at 3; UPS Members Reject, IBT Imposes Contract, CoNVOY Dispatch, Oct. 1987, at 1.

80. See, e.g., Teamsters Are Said to Scrap a Rule on Two-Thirds Vote, N.Y. Times, Oct. 21, 1988, at A14, col. 5; Members: 94,086, Presser: 13,082, Convoy Dispatch, Oct. 1983, at 1; UPS Members Reject, IBT Imposes Contract, Convoy DisPaTch, Oct. 1987, at 1. 
Teamsters', to drastically reduce, if not eliminate, the prospects for successful challenges to incumbent officers at the national level..$^{81}$

Incumbents also have a powerful advantage in direct membership elections of national officers. ${ }^{82}$ The victory of the Miners for Democracy reform slate in the UMW election of 1972 is the great counter-exainple, of course, but even that victory came only in a U.S. Department of Labor supervised election that was virtually compelled by the brutal murders of an earlier reform candidate and his family on the orders of then-UMW president Tony Boyle. ${ }^{83}$ In too many other cases, either the cumbersome enforcement procedures of the Landruin-Griffin Act's election provisions, or the Labor Department's passive approach to enforcement, stymies reform challengers who seek Labor Department lielp in assuring fair elections. ${ }^{84}$

Union reformers traditionally have had much greater success at the local level than at the national. There, the deinocratic reforms imposed by the Landruin-Griffin Act have been inost effective in furthering one of the statute's primcipal purposes: empowering the rank-and-file to clean up corrupt unions theinselves. ${ }^{85}$ But as the Local 560 case illustrates, labor racketeers can soinetimes nip opposition threats in the bud by retaliating economically, and if necessary physically, against rank-and-file dissidents. ${ }^{86}$ The right to run for office and the right to obtain Labor Department assistance in assuring a fair election are of little lielp when potential reform candidates and their supporters are too intimidated even to mount a campaign.

\section{Intra-Union Trusteeships}

When the levels of corruption and racketeering in a union local Inake reform by a local's own members unlikely, the parent international can intervene with a very powerful and effective device for cleaning

81. See J. Edelstein \& M. WARNer, Comparative Union Democracy 72-80 (1975). For a more detailed description and critique of the Teamster electoral system, see infra notes 588-93 and accompanying text.

82. See James, Union Democracy and the LMRDA: Autocracy and Insurgency in National Union Elections, 13 HARV. C.R.-C.L. L. REv. 247 (1978).

83. See P. CLARK, supra note 77, at 26. Another important distinction between the UMW and the IBT, for example, is that those running the Boyle machine, corrupt and brutal though it was, were amateurs in comparison to the mafia figures who have infiltrated the Teamsters.

84. See D. McLaughlin \& A. Schoomaker, The Landrum-Griffin Act and UNion DEMOCRACY 48-50 (1979); James, supra note 82, at 294-313; Rauh, LMRDA-Enforce It or Repeal It, 5 GA. L. REV. 643, 659-66 (1971).

85. See 105 CONG. Rec. 6478 (1959), reprinted in LMRDA LegisLative History, supra note 64, at 1098, 1102, 1105 (remarks of Senator McClellan).

86. See supra text accompanying notes $46-47$. 
house in the local:87 the intra-union trusteeship. Typically, the international will renove all local officers from their posts and will appoint its own trustee to run the local's affairs until the problenis necessitating the trusteeship have been resolved. The union will then hold new elections of local officers and the governance of the local will be returned to its nienibers.

Thus, if the local's officers have been abusing the union's treasury, the trustee can impose more responsible fiscal pohcies; if the officers have been taking payoffs from eniployers to ignore contract violations, the trustee can begin handling grievances nore aggressively; if dispatchers in a local's hiring hall have been taking bribes to allocate work assignments, the trustee can iniplement a firm "first in, first out" dispatch pohicy; if the local's officers have been negotiatimg sweetheart contracts with enployers, the trustee can notify those eniployers that negotiations for future contracts will be legitimate and at arm's length. Indeed, if the trustee can prove that existing contracts are the product of fraud, bribery, or other illegal conduct, she may be able to have then nullified so that legitiniate collective bargaining can commence earlier than would otherwise be possible. ${ }^{88}$ Further, on behalf of the local, the trustee can initiate hitigation pursuant to the Landrum-Griffin Act, RICO, and common law causes of action in order to recover damages for the harm suffered by the local and its inenibers at the liands of the local's former officers and their corrupt managenient counterparts.

The effectiveness of trusteeships as a renedy for union corruption and labor racketeering, however, depends on the willingness of the labor movenient's national leaders to impose them. Most national uinons, which are basically untainted by corruption and determined to stay that way, have leadership that is committed to eradicating corrupt practices. Unfortunately, and not coincidentally, those national unions with the greatest need to resort to trusteeships to expunge racketeer influences at the local level often have been infiltrated at the national level as well.

87. The Landrum-Griffin Act defines a trusteeship as "any ... method of supervision or control whereby a labor organization suspends the autonomy otherwise available to a subordinate body under its constitution or bylaws." 29 U.S.C. $\$ 402(\mathrm{~h})$ (1982). See generally J. BELLACE \& A. Berkowitz, The Landrum-Griffin Act: Twenty Years of Federal Protection of UNION MEMBERS' Rights 98-150 (1979); M. MALIN, supra note 71, at 175-204.

88. Cf. 1 A. CORBIN, Corbin ON CONTRACTs $\S 6(2 \mathrm{~d}$ ed. 1963) (contract induced by fraud is voidable by defrauded party); $6 \mathrm{~A} i d$. $\$ \S 1455$ (bargain made with purpose or effect of defraudimg or in violation of a fiduciary relationship is voidable by the defrauded party); $12 \mathrm{~S}$. WILLISTON, $A$ TREATISE ON THE LAW OF CONTRACTS $\$ \S 1455 A, 1532$ (3d ed. 1970) (recission of contracts obtained through fraud and contracts intended to defraud or injure third parties). See also Pioneer Bus Co., 140 N.L.R.B. 54 (1962) (contract bar rules cannot be used to shield contracts that discriminate between blacks and whites); Paragon Prods. Corp., 134 N.L.R.B. 662 (1961) (contract bar rules cannot be used to shield contracts that contain illegal union security clauses). 
For example, eight years before federal prosecutors succeeded in obtaining a judicially-imposed RICO trusteeship over Tony Provenzano's thoroughly corrupt Teamsters Local 560, rank-and-file Teamsters formally petitioned the Teamsters International to impose a trusteeship of its own. Their request fell on deaf ears. ${ }^{89}$

\section{Other Intra-Union Controls Over Local Unions}

Short of an outright takeover through trusteeship, national unions typically have a myriad of subtle and not so subtle ways to influence their locals. These might include veto power over proposed annendments to the local's bylaws, authority to resolve jurisdictional disputes between sister locals, the ability to grant or withhold strike authorization or strike benefits, and the authority to control the higher levels of contractual grievance procedures. ${ }^{90}$ Through these devices, a national union sometimes can undermine meinbership support for a corrupt but politically entrenched local leader by reducing his effectiveness in collective bargaining or contract enforcement. ${ }^{91}$

A national union also might order the inerger of a corrupt local into one or more of its sister locals, in an effort to dilute and eventually eliminate the local's problems. On the other hand, if the international believes that the prospects for cleaning up one of its locals is particularly hopeless, it imght revoke the local's charter. The international could then charter a new local to assume the old local's jurisdiction; alternatively, it could simply write off the lost members as a sacrifice necessary to prevent the corruption that plagues the expelled local from infecting other parts of the union. The expelled local would probably dissolve, but it could try

89. See Goldberg, Federal Suit Seeks Trusteeship Over N.J. Teamsters Local 560, UNION DEMOCRACY REV., Dec. 1982, at 9; Bid By Teamster Local, N.Y. Times, June 16, 1978, at B24, col. 6.

It also should be noted that trusteeships are two-edged swords that can be abused by a union's national leadership in order to stifle dissent and democratic unionism at the local level. See, e.g., Perm. Subcomm. on Investigations, Comm. on Governmental Affairs, Hotel Employees \& Restaurant Einployees International Union, S. REP. No. 403-14, 98th Cong., 2d Sess. 47-60 (1984). Title III of the Landrum-Griffin Act therefore prohibits a national union from imposing a trusteeship unless it does so with a modicum of procedural fairness and for legitimatc purposes under the statute. However, title III's broad declaration of acceptable purposes for which trusteeships can be imposed, combined with the provision's eighteen-month presumption of validity when the title's procedural requirements are satisfied, allow many abusive trusteeships to pass statutory muster. See Note, Title III of the Labor-Management Relations and Disclosure Act: For Greater Judicial Protection of Union Democracy and Local Autonomy, 9 J. CoRP. L. 271, 295 (1984).

90. See, e.g., Teamsters Const. art. VI, § 4; id. art. XII, §§ 4, 5, 21 (1986); National Master Freight Agreement art. 8, § 1(a) (adopted April, 1985) (principal contract between the IBT and many unionized trucking and freight industry employers).

91. On the other hand, where corruption has reached a union's national level, these means of influencing local affairs can be abused for purposes of undermining the positions of honest and reform-1minded local officers who may be potential challengers to the union's corrupt national leadership. 
to survive as an independent local, or it might obtain a charter from a different national urion more tolerant of corruption. ${ }^{92}$

\section{E. Public Review Boards}

A fundainental problem with all of the internal union remedies discussed thus far is that they usually operate in the context of union governnients that have not institutionalized the checks and balances associated with the separation of powers. ${ }^{93} \mathrm{~A}$ union's legislative functions are, at least in theory, performed by its conventions at the national level and inembership meetings at the local level, and the union's executive functions are carried out by its elected and appointed officers and staff. ${ }^{94}$ But in most unions, no third branch of government exists: the judicial functions are generally handled at the "trial" level by ad hoc hearing tribunals coinprised of officers or meinbers, and at the "appellate" level they are reviewed by the union's executive board or national convention. ${ }^{95}$

As a consequence, the executive officers of the union, particularly the international hierarchy, have the power not only to execute the law of the umion but also to interpret it, thus disregarding the notion that in a deniocratic government "[t] $]$ he executive inust rule not only by law .... [I]t must rule under law."96 Because internal appellate review is usually

92. As alternatives to imposing a trusteeship, either of these approaches has an advantage for the national union in that the provisions of title III of the Landrum-Griffin Act need not be comphed with in most cases. See, eg., Parks v. International Bd. of Elec. Workers, 314 F.2d 886, 924 (4th Cir. 1963) (where revocation of charter was not used as means of evading title III's trusteeship provisions, title III not applicable); UNION TRUSTEESHIPS: REPORT OF THE SECRETARY OF LABOR TO THE CONGRESS UPON THE OPERATION OF TITLE III OF THE LABOR-MANGEMENT REPORTING AND Disclosure ACr 33-34 (1962) (revocation of a charter does not create a trusteeship). Unfortunately, this gap in the Act's coverage sonietimes ean result in the abuse of nergers or charter revocations for purposes of political gerrymandering. An unscrupulous national leadership, for example, might orchestrate the mergers of locals in order to eliminate the local power bases of political rivals within the union.

93. See Brooks, Impartial Public Review of Internal Union Disputes: Experiment in Democratic Self-Discipline, 22 OнIо ST. L. J. 64, 71-73 (1961); Oberer, Voluntary Impartial Review of Labor: Some Reflections, 58 MicH. L. Rev. 55, 58-60 (1959).

94. In practice, however, the distinction between the legislative and executive branches of union goverment often breaks down, with the executive branch holding the doninant position. See Levy, supra note 71, at 673 .

95. See, e.g., TeamsTers Const. art. XIX, $\S \S 1,2$ (1986).

96. Oberer, supra note 93, at 60 . Even when the union's tribunal of last resort is the convention, the union's hierarchy usually controls the outcome. For example, the period between conventions may be as long as five years, and in that period many grievances will becone moot. Thus, for many aggrieved union nembers, the last effective form of internal appellate review will renain with the union's officers. Morcover, the substantive reviews of appcals that do inake it all the way to the convention are often handled by a convention conınittee appointed for that purpose by the national union president or executive board. Finally, a majority of the delegates to most union conventions are already officials at sonie level in the union's hierarchy, and they niay be vulnerable to pressure 
available before any of the union remedies discussed in this section are given final effect, the absence of a separate union judiciary means that those remedies will only be as effective as the union's top leadership will allow them to be. 97

In response to this dilemma, the United Auto Workers (UAW) and a handful of other unions have created semi-mdependent "Public Review Boards" (PRB) to serve as their "supreme courts" for intra-union grievances. ${ }^{98}$ The most successful of these, established by the UAW in 1957, contains seven impartial members appointed from positions outside the union by the International President. Except for its funding, the PRB maintains complete independence from the union hierarchy; it has its own staff, and its offices are located in a building separate from other union offices. ${ }^{99}$

The UAW's PRB has broad authority to hear appeals froin individual union members or from subordinate bodies within the union dealing with internal union matters other than the umion's collective bargaining pohicies. ${ }^{100}$ While most PRB rulings have affirmed executive board decisions, the PRB has overruled the executive board to void fraudulent elections of local officers, has overturned questionable trusteeships, and has

from the top to vote the party line. See generally Craypo, The National Union Convention as an Internal Appeal Tribunal, 22 INDUS. \& LAB. REL. REv. 487 (1969).

97. By the same token, the abuse of these union remedies-such as the expulsion of union dissidents on trumped up charges or the imposition of intra-union trusteeships for illegitimate purposes-may contimue unchecked unless challenged in the courts.

98. The concept was first advanced by Professor Clyde Summers in a report he drafted for the American Civil Liberties Union. ACLU, DEMOCRACY AND LABOR UNIONS: A REPORT AND STATEMENT of Policy (1952). The first public review board was established by the Upholsterers' International in 1953, but it was never very active. Although similar efforts in such other unions as the Packinghouse Workers, the Pulp and Paper Workers, and the American Federation of Teachers have had mixed reviews, the UAW's Public Review Board is widely considered a success. See generally J. Hutchinson, supra note 34, at 375-78; J. StIEBER, W. OBERER \& M. HARRINGTON, DemOCRACY and Public RevieW: AN ANAlysis of the UAW Public Review Board (1960); Brooks, supra note 93; Review Boards: Due Process vs. Power in Union Trial Procedure, UNion DEMOCRACY REV., Winter 1973, at 1. For a discussion of efforts to establish an internal review board within the State, County and Municipal Employees Union, see Ames, The Rise of the AFSCME Judicial Panel, UNION Democracy ReV., Apr. 1982, at 6.

99. UNITEd Automobile, Aerospace and Agricultural IMplement Workers of AMERICA CONST. art. 32, $\S \S 2,9$ (1986). Appointinents to the PRB must be approved by the International Executive Board and ratified by the Convention. Members serve three-year terms (the period between Conventions) and cannot be removed from office until their terms expire. Mid-term replacements, when vacancies arise, are appointed by the International President from a list of names submitted by the remaining members of the PRB. Some of the more distinguished PRB members over the years have included former federal judge and Solicitor General Wade McCree, former Secretary of Labor W. Willard Wirtz, historian Henry Steele Commager, and former president of the University of Michigan Robben Fleming. Klein, The United Auto Workers' Public Review Board, UNION DEMOCRACY REV., Winter 1973, at 2.

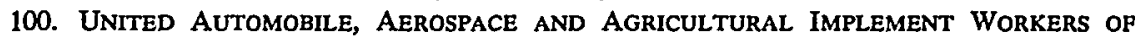
AMERICAN CONST. art. 32, $\S 3$; id. art. 33, $\S \$ 1-2,3(f)$. The PRB nevertheless has jurisdiction over 
ordered reconsideration of improperly adopted local bylaw amendments. ${ }^{101}$ More frequently, the PRB has reversed unfair or retaliatory disciplinary proceedings brought against dissident members, and has upheld the right of rank-and-file members to file charges against their officers. ${ }^{102}$ The PRB has been successful not only as a union court of last resort, but also "as a combination complaint department, inspector general, and conciliation service," and its existence has, at the very least, encouraged the union hierarchy "to pay scrupulous attention to the requirenients of procedure in a given situation."103

In spite of this success-or perhaps because of it-the public review board concept has not met wide acceptance. This is its greatest failure. ${ }^{104}$

\section{F. The Federation's Role}

A fundamental principle of the old AFL was that each national union had coniplete sovereignty over its internal affairs. As one union leader critical of that approach stated, "Autonomy was so sacred that the worst crooks could wrap themselves into a union charter and use it as a license for industrial piracy." 105 The merger of the AFL and the CIO in 1955 did not affect this autonomy principle, and a common assumption is that the AFL-CIO may simply be too loose a federation to play a significant role in cleaning up corrupt affiliates.

However, as the AFL and the CIO demonstrated separately and together during the 1950s, the AFL-CIO can take some steps when it has

some aspects of contract enforcement, such as union misconduct during grievance handling. See Klein, Enforcement of the Right to Fair Representation: Alternative Forums, in THE DUTY OF FAIR REPRESENTATION 97, 103 (J. McKelvey ed. 1977).

101. See, e.g., UAW Review Board Voids Fraudulent Election, UNION DEMocracy Rev., May 1986, at 9; UAW Review Board Voids Trusteeship, UNION DEMOCRACY REV., July 1987, at 6; The UAW Review Board: Part of the Record, UN1ON DEMOCRACY REV., Apr. 1982, at 2, 5 (detailing selected cases in which the PRB acted to overturn international executive board).

102. See, e.g., J. Stieber, W. Oberer, \& M. Harrington, supra note 98, at 14-15, Public Review Board Acts to Uphold UAW's Democractic Tradition, UNION DEMOcRACY REV., April 1982, at 1.

103. J. Stieber, W. Oberer \& M. HARRINGton, supra note 98, at 19, 59. PRB recoinmendations also have led directly to improvements in the UAW's ethical practices codes. See UAW Strenghens Its Ethical Practices Codes, UNION DEMOCRACY REV., July 1986, at 7.

104. An executive director of the UAW's PRB has suggested that PRB's may work best only in those unions that need them the least:

In order for the institution to work at all, it must operate within a framework of basic democratic guarantees .... I have long since concluded that the institution could not effectively operate if faced with an implaceable opposition on the part of the Union's leadership .... It would be casy for union officialdom, simply by withholding key bits of information and data, to thwart the effective operation of independent review.

Klein, supra note 99 , at 2.

105. D. Dubinsky \& A. Raskin, David Dubinsky: A Life With Labor 156 (1977). 
the will to act. The Federation's most important source of leverage over its affiliates is its power to suspend or expel them from membership, and that power has been quite effective agamst some unions. For example, in 1949 and 1950, the CIO expelled eleven unions for alleged Communist domination; soon after, nine of the eleven had either gone under or had been absorbed by rival unions. ${ }^{106}$ Corruption replaced communism on center stage a few years later, and the AFL-CIO successfully expelled the corrupt Bakery and Confectionary Workers International Union in 1957, chartering a new American Bakery and Confectionary Workers Union which assumed control over niany of the expelled union's locals and members. Eventually, the reninants of the older union cleansed its ranks, and the two unions merged. 107

On the other hand, expulsions of the International Longshoremen's Association (ILA) and the Teamsters were total failures, demonstrating that exile from the house of labor is not necessarily an effective remedy against labor racketeering. In 1953, following dranıatic revelations by the New York State Crime Commission of corruption reaching the highest levels of the ILA, the AFL expelled the ILA and, with no lasting success, attempted to organize a rival International Brotherhood of Longshorenien (IBL) to displace the ILA from the New York waterfront. ${ }^{108}$ The ILA defeated the IBL in a series of bitterly contested National Labor Relations Board (NLRB) elections, and by late 1959 the AFL-CIO invited the ILA to reaffiliate. ${ }^{109}$ Similarly, the Teamsters umion seems to have suffered few ill effects from its thirty-year exile from the Federation, which began after Hoffa's election in 1957 and ended anticlimactically im 1987.110

These failures, however, do not mean that the AFL-CIO is totally powerless to combat corruption in its affiliates. Many affiliates, particularly the smaller ones, do not rehish the prospect of survival on their own.

106. C. LARROWE, HARRY BRIDGES: THE RISE AND FALL OF RADICAL LABOR IN THE U.S. 325 (2d ed. 1972). Whatever one's opinion of the labor movement's post-war purge of the left, it is difficult to deny its effectiveness, although the rampant anti-communist hysteria of the period certainly facilitated that effectiveness. See generally D. CAUTE, THE GREAT FEAR: THE ANTI-COMMUNicst PURge UNDER TRUMAN AND EISENHOWER (1978).

107. See J. HutChinson, supra note 34, at 320-24; P. TAFT, supra note 28, at 58, 61.

108. See V. Jensen, Strife on the Waterfront: The Port of New York Since 1945, at 95-135 (1974). In a last-minute bid to avoid explusion, the ILA offered to submit to a receivership so that it conld reform itself under AFL supervision. Id. at 111. It is interesting to speculate whether that route would have been any more effective than the AFL's futile expulsion of the ILA.

109. See id. at 241. The invitation to reaffiliate was apparently made in part to head off the formation of a rival labor federation comprised of the recently expelled Teamsters, the west coast International Longshoremen and Warehousemen Union (ILWU), and the ILA. See id. at 229-30. (The ILWU had been expelled from the CIO in 1950 because of its allegedly Communist leadership. C. LARROWE, supra note 106, at 323-25).

110. See Matlack, Taking on the Teamsters, 19 NAT'L J. 2782 (1987). 
For example, during the same period in which the ILA and IBT expulsions were failing, the fear of expulsion and its consequences led the Distillery Workers, the Allied Industrial Workers, the United Textile Workers, and the Jewelry Workers to accept something resembling Federation "trusteeships": each union was placed on probationary status, during which time the Federation appointed "monitors" to supervise the affairs of the unions and assist in the elimination of corruption. 111

The AFL-CIO also might fight corruption both in its affiliates and in unaffiliated unions by considering comparative levels of corruption in conipeting unions when resolving jurisdictional disputes, by providing financial or technical support for reformers in corrupt unions, or by refusing to honor the picket lines or otherwise lend support to the activities of certain "outlaw" unions that could be placed on a "boycott" list. These approaches, however, would constitute major departures from longstanding AFL-CIO practice, and-given the political realities in a Federation that recently welcoined back the Teamsters without even a word about Teamster corruption - they are unlikely to be tried anytime soon.

Indeed, the AFL-CIO's current indifference to the problem of corruption within its ranks is typified by the fact that its etlical practice codes, adopted with great fanfare in the 1950s, are now out of primt within the Federation. The ethical practices committee establislied to enforce them has been dorinant for decades. ${ }^{112}$

\section{LEGAL AUthoRITY FOR THE JUDICIALly SUPERVISED REFORM OF LABOR UNIONS}

Internal union remedies have proven imadequate to eliminate the corruption and racketeering that lias plagued soine segments of the labor inovenient for decades. Countless criminal prosecutions and civil suits for routine injunctive rehef ${ }^{13}$ or daniages against corrupt union officials and their manageinent counterparts also have proved ineffective. Sucl1

111. See J. HuTchinson, supra note 34 , at 308-20, 324-28.

112. See D. DubinSKY \& A. RASKIN, supra note 105 , at 168 . Copies of the ethical practices codes are available from the Association for Union Democracy.

113. Reformers have frequently obtained injunctions requiring unions to comply with specific requirements of the law, see, e.g., Mallick v. International Bhd. of Elec. Workers, 749 F.2d 771, 785 (D.C. Cir. 1984) (union ordered to permit reformers to inspect union financial records); McCabe v. International Bhd. of Elec. Workers, Local Union 1377, 415 F.2d 92, 97-98 (6th Cir. 1969) (union ordered to discontimue unauthorized expenditures), and they have occasionally obtained orders voiding provisions in union constitutions, see, e.g., Pawlak v. Greenawalt, 628 F.2d 826, 831 (3d Cir. 1980) (injunction against enforcenient of umion's constitutional provision authorizing imposition of fines against menibers who sue the union without first exhausting internal union remedies); see generally Note, Facial Adjudication of Disciplinary Provisions in Union Constitutions, 91 YALE L.J. 144 (1981) (urging inore frequent application of this remedy), but they have rarely obtamed anything approaching the kind of structural injunctions that are the focus of this Article. 
cases often succeed in jailing an offender here or halting an abuse there, but as the sordid history of Tony Provenzano's Teamsters Local 560 illustrates, they fail to root out deeply entrenched patterns of labor racketeering. 114

The failure of traditional remedies to elimmate corruption from unions like the Teamsters has led growing numbers of law enforcement offcials, and soine umion reforiners, to embrace the much more controversial and drastic remedy of court-imposed trusteeships as a means of reinedying the inost severe instances of labor racketeering. ${ }^{115}$ Frustration with the inadequacy of less drastic ineasures alone, though, cannot provide the legal authority for such trusteeships, or for any other similarly mtrusive efforts by the courts to supervise a union's internal affairs. Nor does adequate discussion of the sources of that authority appear in the emerging lime of cases, beginning with Local 560 itself, in which courts have actually imposed such re1nedies. ${ }^{116}$

This section and the next, therefore, endeavor to provide some of that missing analysis. First, a review of the emergence over the last several decades of imstitutional reform litigation in other substantive areas provides a context for the discussion. The next four subsections examine the more direct precedents for union reforn litigation, many involving the use of such traditional equitable devices as masters and receivers in a variety of union settings. The Article then analyzes the structural injunctions available under the RICO statute, which provides the basis for five recent or ongoing union trusteeships, monitorships, and decreeships.

\section{A. Traditional Equitable Remedies and the Emergence of Institutional Reform Litigation}

Equity, it has long been said, will not suffer a wrong without a remedy. ${ }^{117}$ Accordingly, "equity has been characterized by a practical flexibility in shaping its reinedies." 118 That flexibility has been stretched to

114. See infra text accompanying notes 364-424.

115. E.g., Benson, Now or Never! Oust Racketeers From Unionsl, UNION DEMOCRACY REv, Nov. 1987, at 3; PRESIDENT's CoMmission, supra note 14, at 253-54.

116. See, e.g. United States v. Local 560, Int'l Bhd. of Teamsters (Local 560 III), 780 F.2d 267, 295-96 (3d Cir. 1985), cert. denied, 476 U.S. 1140 (1986); United States v. Local 30, United Roofers Ass'n, 686 F. Supp. 1139, 1167-68 (E.D. Pa. 1988). See also infra text accompanying notes 463-89. As Owen Fiss has observed, "[O]ne of the most striking features of opinions in structural [reform] cases [is] the failure to discuss the remedy with any specificity at all." Fiss, supra note 25, at 52 n.105.

117. See, e.g., H. MCClintock, HANDBook of THE Principles of Equity 76 (2d ed. 1948).

118. Brown v. Board of Educ., 349 U.S. 294, 300 (1955). 
dramatic new limits in the last twenty-five years, first in school desegregation and later in such areas as the reform of prisons and inental institutions, as the courts have responded to the development of new substantive rights by entering "squarely in[to] the business of reforming bureaucracies."119

Because of the inherently difficult and protracted nature of reforming complex social institutions, particularly when reform is forced upon resistant bureaucracies from the outside, institutional reform hitigation has been accoinpanied, perhaps inevitably, by a transformation of traditionally equitable remedies into new and sometimes controversial forms. The injunction, for exaniple, one of equity's inost basic remedies, assumed a new look as a result of the legal revolution brought about by the civil rights movement. ${ }^{120}$ The notion that injunctive relief is "extraordimary" has all but disappeared. ${ }^{121}$ The injunction is no longer a "one-shot inethod" of reform. In institutional reform cases, "a series of interventions" are inevitable, and the injunction represents the initiation of a "relationship between the judge and the institution"-a declaration that the judge will henceforth manage "the reorganization of an ongoing social institution." 122

Judges soon learned, lowever, that supervising institutional reform witlrout outside help was often impossible. Therefore, relying on their "inherent power to provide themselves with appropriate instruments required for the performance of their duties," 123 they created new roles for such traditional ancillaries of the equity courts as masters and receivers. The master, for example, evolved from the traditional pre-disposition factfinder to the post-hiability formulator, momtor, and enforcer of remedial decrees. ${ }^{124}$ Similarly, receivers were no longer limited to their traditional function of holding, managing, or liquidatimg a defendant's

119. Horowitz, supra note 25, at 1287; see also Kirp \& Babcock, Judge and Company: CourtAppointed Masters, School Desegregation, and Institutional Reform, 32 ALA. L. REv. 313 (1981); Comment, Confronting the Conditions of Confinement: An Expanded Role for Courts in Prison Reform, 12 HARv. C.R.-C.L. L. REv. 367 (1977); Note, The Wyatt Case: Implementation of a Judicial Decree Ordering Institutional Change, 84 YALE L.J. 1338 (1975).

120. See generally O. Fiss, The Civil Rights InJunction (1978).

121. See Chayes, supra note 25 , at 1292.

122. O. Fiss, supra note 120 , at $28,92$.

123. Ex parte Peterson, 253 U.S. 300, 312-13 (1920).

124. See Horowitz, supra note 25 , at 1274. Courts utilizing masters in this way have often. referred to them by a variety of titles, such as "administrator," "monitor," and "hearing officer." See Special Project, The Remedial Process in Institutional Reform Litigation, 78 ColUM. L. REV. 784, 826-35 (1978). See generally Berger, Away From the Court House and Into the Field: The Odyssey of a Special Master, 78 Colum. L. Rev. 707 (1978); Brakel, Special Masters in Institutional Litigation, 1979 AM. B. Found. REs. J. 543; Kirp \& Babcock, supra note 119, at 553-64; Nathan, The Use of Masters in Institutional Reform Litigation, 10 Tol. L. REV. 419. 
property in order to protect a plaintiff's interest in that property. ${ }^{125}$ For two decades, courts facing unusually fierce resistance in institutional reform cases have appointed receivers to assume the day-to-day adininistration of complex social institutions in order to protect such intangible constitutional rights as the right to an integrated public school education, or the right to be free from cruel and unusual punishment in a state prison system. ${ }^{126}$

Nothing in the court's "inherent equitable powers" should limit these adaptations of traditional equitable remedies to cases involving constitutional rights or public agencies. ${ }^{127}$ True, when reforming private organizations such as unions, ${ }^{128}$ courts inust take special care to accominodate the first ainendment's freedoin of association, ${ }^{129}$ a concern less often present in the reform of public bureaucracies. But on the other hand, two of the strongest argunients against the use of intrusive, structural remedies in the public sector-that they violate fundamental principles of federalisin and the separation of powers ${ }^{130}$-are much less relevant to institutional reform hitigation in the private sector.

This conclusion is consistent with the view that it is not the nature of the reniedies involved as inuch as the emergence of the new substantive rights underlying those reniedies that has inade the judicially supervised reform of public institutions so controversial. ${ }^{131}$ Indeed, even apart from the trusteeships routinely established in bankruptcy cases, courts have utilized receiverships regularly, and without great controversy, to enforce substantive rights in the private sector since long before the first

125. See Note, Receivership As a Remedy in Civil Rights Cases, 24 RUTGERs L. REv. 115, 132 (1969).

126. See, e.g., Morgan v. McDonough, 540 F.2d 527, 535 (1st Cir. 1976), cert. denied, 429 U.S. 1042 (1977) (high school); Newman v. Alabama, 466 F. Supp. 628, 635 (M.D. Ala. 1979) (prison); Turner v. Goolsby, 255 F. Supp. 724, 730 (S.D. Ga. 1966) (school system). See generally Comment, Equitable Remedies: An Analysis of Judicial Utilization of Neoreceiverships to Implement Large Scale Institutional Change, 1976 WISC. L. REv. 1161 (1976); Note, supra note 125.

127. See Fiss, supra note 25 , at 44 n. 92 .

128. Although it has been argued that union activity should be treated as state action because much union power is derived from federal labor law, see, e.g., Steele v. Louisville \& N.R.R., 323 U.S. 192, 208 (1944) (Murphy, J., concurring); R. POSNER, ECONOMIC ANALYSIS OF LAW 248, 532 (2d ed. 1977), that view has been repeatedly rejected by the Supreme Court, see, e.g., United Bhd. of Carpenters, Local 610 v. Scott, 463 U.S. 825, 832-33 (1983); United Steelworkers v. Sadlowski, 457 U.S. 102, 117 (1982). See generally Klare, The Public/Private Distinction in Labor Law, 130 U. PA. L. REV. 1358 (1982).

129. See infra notes $342-61$ and accompanying text.

130. See Frug, The Judicial Power of the Purse, 126 U. PA. L. REv. 715, $743-49$ (1978); Mishkin, Federal Courts as State Reformers, 35 WASH. \& LEE L. REV. 949, 967-71, 975-76, (1978); Nagel, Separation of Powers and the Scope of Federal Equitable Remedies, 30 STAN. L. REv. 661, 664-81 (1978). For counterarguments, see Eisenberg \& Yeazell, The Ordinary and the Extraordinary in Institutional Litigation, 93 HARv. L. REv. 465, $501-06$ (1980); Fiss, supra note 25, at 11-17, 36-39.

131. See, e.g., Eisenberg \& Yeazell, supra note 130, at 501-06; Fiss, supra note 25, at 51-56. 
school desegregation receivership. For example, in the corporate law area, courts have frequently appointed receivers to take charge of defendant corporations in order to enforce coinpliance with the securities laws. ${ }^{132}$ Antitrust law recognized the availability of corporate receivers to enforce coinphiance as long ago as $1911 .^{133}$

This pattern also holds true in the context of labor unions. Both state and federal courts have, for over fifty years, regularly relied upon their inherent equitable powers to appoint niasters and receivers to reinedy violations of the substantive laws regulating internal union affairs.

\section{B. Common Law Union Receiverships, Before Landrum-Griffin... and After}

The first suggestion that receivers could play a role in resolving internal union disputes appears in a 1932 New York case, Kaplan v. Elliot. ${ }^{134}$ A corrupt New York local which represented inotion picture projectionists had been placed in an intra-union trusteeship by its international. The ousted local president challenged the trusteeship, alleging breaches of the union's constitution, and sought reinstatenient pendente lite. The court denied the injunction but ordererd the international to conduct an election of teniporary officers. It also indicated that, had the parties requested, it would "have been pleased to appoint" an impartial official of the American Federation of Labor "to act as receiver of the funds of the local," pending a final decision on the inerits. ${ }^{135}$

When the international subsequently coinplained that conditions in the local inade fair elections impossible, the court on its own motion appointed three receivers to hold and preserve the local's property and "to

132. See, e.g., SEC v. S \& P Nat'l Corp., 360 F.2d 741, 750-51 (2d Cir. 1966); Los Angeles Trust Deed \& Mortgage Exch. v. SEC, 285 F.2d 162, 181-82 (9th Cir. 1960), cert. denied, 366 U.S. 919 (1961). Although the Investment Company Act of 1940 expressly authorizes the appointment of "trustee[s]" to remedy certain violations, 15 U.S.C. $\$ 80 \mathrm{a}-41$ (d) (1982 \& Supp. V 1987), the other major securities statutes mention only injunctions as available equitable remedies. E.g., Securities Act of 1933, 15 U.S.C. $\S 77 t$ (b) (1982 \& Supp. V 1987); id. § 77v(a); Securities Exchange Act of 1934,15 U.S.C. $\& 78$ u(e) (1982 \& Supp. V 1987). Therefore, most courts that have imposed receiverships in SEC enforcement proceedings have relied at least in part, and often exclnsively, on their inherent equitable powers. See Farrand, Ancillary Remedies in SEC Civil Enforcement Suits, 89 HARV. L. REV. 1779, 1780-81, 1788 (1976).

133. See United States v. American Tobacco Co., 221 U.S. 106, 186-88 (1911); see also United States v. E.I. Du Pont de Nemours \& Co., 366 U.S. 316, 326-35 (1961).

134. 145 Misc. 863, 870, 261 N.Y.S. 112,119 (Sup. Ct. 1932). In one earlier case, receivers had been appointed to take charge of the funds of a union that had been ordered dissolved. Kealey v. Faulkner, 18 Ohio Dec. 498 (Cuyahoga C.P. 1907). In another, several employers forced a union into receivership as a result of litigation growing out of an ongoing labor dispute, but the receivership was overturned on appeal. District No. 21, UMW v. Bourland, 169 Ark. 796, 807, 277 S.W. 546, 551 (1925).

135. Kaplan, 145 Misc. at $869-70,261$ N.Y.S. at 119-20. 
supervise the rights of individual members in their relation to the union and in the preservation of their contractual rights."136 Although an appellate court later overturned the receivership, ${ }^{137}$ it did so without opinion. Commentators at the time generally supported the availability of umon receiverships under appropriate circumstances and speculated that the Kaplan reversal was less a rejection of union receiverships per se than a ratification of the international's intra-union trusteeship in the particular case. ${ }^{138}$

Whatever Kaplan's meaning, a line of New Jersey cases that developed only a few months later left no ambiguity. The first involved a "paper" Teamsters local estabhished for the sole purpose of extorting dues payments from members who in fact received no union representation. ${ }^{139}$ When, pursuant to allegations of fraud and breach of trust, the court appointed a custodial "receiver-trustee" to manage the local's funds pendente lite, it stressed that its "inherent jurisdiction" to make such an appointment "is beyond question [and] does not depend upon or require statutory authority therefor."140

Subsequent union receiverships provide more ambitious efforts at institutional reform. The second New Jersey case, for example, Local 11, International Association of Bridge, Structural and Ornamental Ironworkers v. McKee, ${ }^{141}$ involved a local which was not merely a dues collecting scam but instead was a legitimate union incapacitated by corruption, autocratic leadership, and a two-and-a-half year suspension of membership meetings. In an action based on fraud and violations of the union's constitution, the plaintiffs requested the apppointment of a receiver endowed with "all of the powers, duties, and functions" of union officers, specifically including the power to conduct membership meetings and, when the court deemed appropriate, new elections of officers. ${ }^{142}$

136. Kaplan v. Elliot, N.Y.L.J., Jan. 5, 1933, at 57. The court later modified its order to establish a two-member committee-one member named by the local and the second by the international-to run the local's day-to-day affairs, subject to the supervision of the receivers, who maintained complete control over the local's funds. See Comment, Appointment of Receivers for Labor Unions, 42 YALE L.J. 1244, 1246 (1933).

137. Kaplan v. Elliot, N.Y.L.J., Jan. 24, 1933, at 56 (App. Div. 1st Dep't 1933).

138. See e.g., Recent Case, 46 HARv. L. Rev. 1037, 1038 (1933) (stating that the decision in Kaplan may have rested on the fact that the constitution and bylaws of the Union provided an alternative remedy); Note, $A$ Forward Step in Labor Regulations, 7 ST. JoHN's L. REV. 316, 317 n. 6 (1933) (supporting appointment as only way evils of local mismanagement can be prevcnted). But see Comment, supra note 136 , at $1248-50$ (discussing theoretical justification for court appointed receivers, but noting union self-policing could justify a court's forbearance of such action).

139. Chalghian v. International Bhd. of Teamsters, Local 617, 114 N.J. Eq. 497, 169 A. 327 (Ch. 1933).

140. Id. at 501,169 A. at 329.

141. 114 N.J. Eq. 555, 169 A. 351 (Ch. 1933).

142. Id. at $558-59,169 \mathrm{~A}$. at 353 . 
Again relying on its "general equity powers" and its "inherent jurisdiction," the court obliged by appointing a receiver not only to preserve the union's assets, but also to "operate its business in a legal manner, free of oppression by interlopers such as the International officers" until the election of new officers. ${ }^{143}$

Another New Jersey case was apparently the first in which a receiver himself petitioned the court for assistance in overcoming the defendant union's resistance to the receivership's operation. ${ }^{144}$ In that case, the court expressly endorsed an activist role for receivers, noting that sometimes "the status quo is a condition not of rest but of action," 145 and under such circumstances, "[t]he receiver cannot reinain quiescent. . . . Inactivity by hinı would jeopardize the existence of the local . . ."146 The dearth of precedent in the area did not faze the court: "If there be no precedent $\mathrm{n} 1$ this state to fit the instant case, then one will be established. Where there is a wrong, there is a remedy." 147

Courts eventually ordered the use of receivers or special masters in union corruption and union democracy hitigation not only in New York and New Jersey, ${ }^{148}$ but in Alabaina, ${ }^{149}$ Illinois, ${ }^{150}$ Indiana, ${ }^{151}$ Missouri, ${ }^{152}$ Oregon, ${ }^{153}$ and Pennsylvania ${ }^{154}$ as well. Courts sometnnes used the threat of receiverships as a means of compelling structural reforms in

143. Id. at $566,169 \mathrm{~A}$. at $354-55$.

144. Mullins v. Merchandise Drivers Local 641, 120 N.J. Eq. 307, 185 A. 51 (Ch. 1936).

145. Id. at 312, 185 A. at 53 (quoting Toledo, A.A. \& N.M. Ry. v. Pennsylvania Co., 54 F. 730, 741 (C.C.N.D. Ohio 1893), appeal dismissed, 150 U.S. 393, 401 (1893)).

146. Id. at $311,185 \mathrm{~A}$. at 53 .

147. Id. at $309,185 \mathrm{~A}$. at 52 .

148. See supra text accompanying notes 134-47; see also Sibilia v. Western Elec. Employees Ass'n, 142 N.J. Eq. 77, 80, 59 A.2d 251, 253 (1948); Collins v. International Alliance of Theatrical Stage Employees, 119 N.J. Eq. 230, 246-47, 182 A. 37, 45-46 (Ch. 1935).

149. See Clinton v. Hueston, 308 F.2d 908, 911 (5th Cir. 1962) (vacating, following removal to federal court, appointment by Alabama state court pursuant to Alabama law of a receiver pendente lite in case involving alleged Landrum-Grifin Act violations).

150. In August, 1940, an Illinois chancery court placed Chicago's Local 278 of the Hotel and Restaurant Employees Union in receivership due to its infiltration by organized crime. See S. REP. No. 621, 86th Cong., 1st Sess., pt. 2, at 598-601 (1959) (the McClellan Committee's Second Interim Report).

151. See Mills v. Collier, 50 Lab. Cas. (CCH) I 19,150 (S.D. Ind. June 9, 1964) (rejecting challenge, brought under title III of the Landrnm-Grifin Act, to a union receivership imposed by state court pursuant to state law).

152. Robinson v. Nick, 136 S.W.2d 374, 385 (Mo. Ct. App. 1940) ("the appointment of a receiver . . . may be exercised in a pending case as a means of preventive justice").

153. Mursener v. Forte, 186 Or. 253, 272, 205 P.2d 568, 577 (1949) (upholding receivership to protect dissipation of union funds by International officers pending election of new Local officers).

154. O'Neill v. United Ass'n of Journeymen, 348 Pa. 531, 538, 36 A.2d 325, 328 (1944) (master appointed to supervise local union elections). 
unions, ${ }^{155}$ and sonie defendants accepted receiverships voluntarily. ${ }^{156}$ Even when courts were reluctant to appoint receivers, they sometimes achieved a similar effect by issuing extremely detailed, mandatory injunctions. ${ }^{157}$

By the late 1950s, then, the court-imposed union receivership had a twenty-five year track record in urion reform hitigation. While it was considered a harsh reniedy, inost commentators nevertheless understood the receivership to be available in extrenie cases. ${ }^{158}$ And since few would deny that the corruption and racketeering in the Teanisters union in the late 1950 s was extrenie, ${ }^{159}$ it was not all that surprising when a bold group of union reformers sought to place an entire union international into receivership following Jimmy Hoffa's election to the Teanisters' presidency in 1957.160 Although the Cunningham v. English litigation resulted in a consent decree establishing a court appointed "Board of Morntors," rather than a receivership, to oversee major reforms in the Teanisters union, ${ }^{161}$ that case was undoubtedly the high-water mark of union reform hitigation in the pre-Landrum-Griffin Act era. It remains one of the most ambitious efforts at judicially supervised union reform ever undertaken. ${ }^{162}$

But in the end, the Board of Monitors was widely viewed as a failure. The common law union receivership subsequently fell into disuse, in

155. See, e.g., Gilligan v. Moving Picture Mach. Operators, 135 N.J. Eq. 484, 487-88, 39 A.2d 129, 131-32 (1944) (upholding order threatening receivership unless union amended constitution to establish a serriority system for allocating work).

156. See, eg., Yellin v. Schaefer, 46 L.R.R.M. (BNA) 2723 (N.Y. Sup. Ct. June 27, 1960) (part of earlier settlement was a court-supervised general election of union officers); Holderman v. International Org. of Masters, 7 A.D.2d 1021, 1022, 184 N.Y.S. 2d 698, 699 (1959) ("action was settled in open court before a Special Referee"); Kegg v. Bianco, 89 'PrTT. LEG. J. 447, 448 (Pa. C.P. 1941) (counsel for parties permitted appointenent of receiver to conduct union's duties, hold an election, and report to the court).

157. See, e.g., Dusing v. Nuzzo, 263 A.D. 59, 63-65, 31 N.Y.S. 2d 849, $852-54$ (1941) (establishing procedures for election of union offieers).

158. See, eg., Katz \& Friedman, Members' Control Over Officers, Elections, and Finances: Equitable Remedies and Modern Developments, 22 OHIO ST. L.J. 97, 101-03 (1961); Suunmers, Judicial Regulation of Union Elections, 70 YALE L.J. 1221, 1255 (1961); Comment, Disputes Within Trade Unions, 45 YALE L.J. 1248, 1268 (1936); Recent Case, supra note 138, at 1038; Note, supra note 138, at 317 n.6. Even Archibald Cox, who expressed the view that court-imposed receiverships were "intolerable" in the labor context, never argued that such receiverships were unavailable as a matter of law. Cox, The Role of Law in Preserving Union Democracy, 72 HARv. L. Rev. 609, 634 (1959).

159. See, e.g., S. Rep. No. 1139, 86th Cong., 2d Sess. (1960); S. Rep. No. 621, 86th Cong., 1st Sess. (1959); S. REP. No. 1417, 85th Cong., 2d Sess. (1958) (reports of the McClellan Committee).

160. See infra text accompanying notes 499-503.

161. Consent Order, Cunningham v. English, C.A. $2361-57$ (D.D.C. Jan. 31, 1958), reprinted in English v. Cunningham, 269 F.2d 517, 532-35 (D.C. Cir.), cert. denied, 361 U.S. 905 (1959).

162. See infra text accompanying notes 492-572; Goldberg, The Teamsters Board of Monitors: An Experiment in Union Reform Litigation, 30 LAB. HisT. 563 (1989). 
large part because of the passage in 1959 of the Landruin-Griffin Act. ${ }^{163}$ The Act was a direct response to the corrupt and undenocratic union practices exposed by the McClellan Committee, and it provided alternative reinedies to inany of the abuses that the common law receiverships had been designed to remedy. ${ }^{164}$ Indeed, many of those receiverships had been ordered in response to abuses in the elections of union officers, and the coinprehensive election reinedies available under Landrun-Griffin's title IV would now preenpt suits to overturn such elections. ${ }^{165}$

Nevertheless, apart from the statute's express limit on post-election reinedies to those made available to the Secretary of Labor pursuant to title IV, ${ }^{166}$ nothing in the Landrum-Griffin Act preempts otherwise available state or federal remedies for union corruption or undernocratic practices. ${ }^{167}$ On the contrary, three separate provisions of the Act expressly provide for the retention of rights under other sources of law. ${ }^{168}$ According to the only court which has addressed the question, "One of the rights preserved [by those provisions] is the right [of a umion member] to seek the imposition of a state court receivership over his local umion to insure the financial stability of his union and to assure its proper operation as a labor organization." 169 Indeed, the common law remedies for union corruption-including court-appointed receiverships-niay be inore readily available today than they were thirty or forty years ago,

163. Pub. L. No. 86-257, 73 Stat. 519 (1959) (codified as amended at 29 U.S.C. $\S \S 401-531$ (1982 \& Supp. V. 1987)).

164. Title I of the Landrum-Griffin Act, $\S \S 101-05,29$ U.S.C. $\S \S 411-15$ (1982)-the "Bill of Rights of Members of Labor Organizations"-protects union members' civil liberties within unions, such as the right to equal treatment, freedom of speech and assembly, and protection against improper disciplinary action; title II, id. $\S \S 201-10,29$ U.S.C. $\S \S 431-41$, imposes reporting and disclosure requirements on unions and union officers; title III, id. $\S \S 301-06,29$ U.S.C. $\S \S 461-66$, establishes hinits on the power of national or international labor organizations to impose intra-union trusteeships on their affiliates; title IV, $i d . \S \S 401-04,29$ U.S.C. $\S \S 481-83$, regulates the election of union officers; and title V, id. $\S \S 501-04,29$ U.S.C. $\S \S 501-04$, defines and provides for the enforceinent of the fiduciary responsibilities of union officers. See generally J. BELLACE \& A. BERKowITZ, supra note 87, at 1-313; M. MALIN, supra note 71, at 33-346.

165. Landrum-Griffin Act $\S \S 401-04,29$ U.S.C. $\S \S 481-83$ (1982).

166. Id. § 403, 29 U.S.C. $\S 483$.

167. Nor does the Norris-LaGuardia Act, 29 U.S.C. $\S \S 101-15$ (1982 \& Supp. V 1987), which limits the power of the federal courts to issue imjunctions in labor disputes, affect the availability of injunctions or other equitable remedies in cases involving internal union affairs. See Cunningham v. English, 41 L.R.R.M. (BNA) 2022, 2028 (D.D.C. 1957), modified on other grounds sub nom. Teamsters v. Cunningham, 41 L.R.R.M. (BNA) 2044 (D.C. Cir. 1957); Fitzgerald v. Abramson, 89 F. Supp. 504, 509 (S.D.N.Y. 1950); Cliambers v. International Hod Carriers' Building and Comınon Laborers Union, 52 F. Supp. 978, 979-80 (D.D.C. 1943).

168. Landrum-Griffin Act $\S \S 103,306,603,29$ U.S.C. $\S \S 413,466,523$ (1982). See generally Sumners, Pre-emption and the Labor Reform Act-Dual Rights and Remedies, 22 OHIO ST. L.J. 119 (1961) (outlining inpact of the Act on existing law; provides history of the savings clauses of titles I, III and V).

169. Mills v. Collier, 50 Lab. Cas. (CCH) \1 19,150, at 32,033 (S.D. Ind. June 9, 1964). 
since old questions about a union's capacity to be sued ${ }^{170}$ and a federal court's jurisdiction to entertain suits to enforce a union's constitution have since been settled in favor of plaintiffs. ${ }^{171}$

The coinmon law doctrinal foundations of the union receivership, which have lain dormant for nearly thirty years, inay seem quaint and obsolete in light of the statutory causes of action available under the Landrum-Griffin Act and civil RICO. Nevertheless, just as a resurgence of interest in state constitutional law has emerged in response to the shifting tides of federal constitutional analysis, ${ }^{172}$ resort to the old coininon law doctrines may ultimately provide an attractive alternative to their more modern statutory counterparts in the context of union reform litigation.

In any event, the receivership reinedy reinains available under the Landrum-Griffin Act. ${ }^{173}$ Congress created three causes of action in the Act which authorize in broad language the courts to grant any "relief (including injunctions) as inay be appropriate" to enforce title I's "Bill of Rights of Members of Labor Organizations," title II's reporting and disclosure requirements, and title III's protections against inproper intraunion trusteeships. ${ }^{174}$ Sinilarly, title V's provision authorizing ineinbers to brimg suit on their union's behalf against corrupt union officers for breach of their fiduciary duties provides not only for damages or an accounting and attorneys' fees but also for any "other appropriate rehef." 175

170. See, e.g., Forkosch, The Legal Status and Suability of Labor Organizations, 28 TEMPLE L.Q. 1 (1954) (48 state survey of conflicting state decisions on this issue).

171. Section 301(a) of the Labor Management Relations Act, 29 U.S.C. $\S 186(a)$ (1982), has been construed to provide a federal jurisdictional and substantive basis for suits to enforce union constitutions, even where those disputes do not directly impact collective bargaining. See, e.g., United Ass'n of Journeymen v. Local 334, United Ass'n of Journeymen, 452 U.S. 615, 627 (1981); Lewis v. International Bhd. of Teamsters Local 771, 826 F.2d 1310, 1314 (3d Cir. 1987); Kinney v. International Bhd. of Elec. Workers, 669 F.2d 1222, 1229 (9th Cir. 1982).

172. See, e.g., Brennan, The Bill of Rights and the States: The Revival of State Constitutions as Guardians of Individual Rights, 61 N.Y.U. L. REv. 535, 548 (1986) ("the diminution of federal scrutiny and protection out of purported deference to the states mandates the assumption of a more responsible state role. And state courts have taken seriously their obligation as coequal guardians of civil rights and liberties.")

173. See, e.g., Hood v. Journeymen Int'1 Union, 454 F.2d 1347, 1356 (7th Cir. 1972) (upholding receivership, pursuant to title $\mathrm{V}$ of the Landrum-Griffin Act, over a union-controlled pension fund.); cf. Fanning v. United Scenic Artists, Local 829, 265 F. Supp. 523, 527 (S.D.N.Y. 1966) (denying preliminary injunctive relief, including the appointment of a receiver, to remedy alleged LandrumGriffin Act violations, due to absence of irreparable harm and small probability of success on the merits, but not denying that a receivership would be available if plaintiffs prevailed on the merits); Marin v. Union de Empleados de Muelles, 46 L.R.R.M. (BNA) 2744, 2745 (D.P.R. 1960) (appointing monitor, pursuant to consent order, to insure protection of members' Landrum-Griffin Act rights).

174. Landrum-Griffin Act $\S \S 102,210,304(a), 29$ U.S.C. $\S \S 412,440,464$ (a) (1982).

175. Id. $\S 501(b), 29$ U.S.C. $\S 501(b)$ (1982). 
Only in the limited context of post-election enforcement of title IV's fair election provisions did Congress expressly consider and reject specific equitable remedies, such as receiverships for the purpose of admimistering a umon's affairs while an election challenge is pending. ${ }^{176}$ But even there, the Act permits receiverships of a more limited nature, since it authorizes a court "to take such action as it deems proper to preserve the assets of the labor organization."177 At least one court has appoimted a trustee for such purposes in a title IV proceeding. ${ }^{178}$

Thus, with the exception of post-election enforcement of title IV's fair election provisions, there is no reason to beheve that Congress intended to deny courts their traditional equitable powers in remedying violations of the Landrum-Griffin Act. Congress used broad, open-ended language in describing the remedies available under the Act, and it was undoubtedly aware that as a remedial statute, Landrum-Griffin would be liberally construed. ${ }^{179}$ As the Supreme Court has repeatedly held, "Unless a statute in so many words, or by a necessary and inescapable inference, restricts the court's jurisdiction in equity, the full scope of that jurisdiction is to be recognized and applied." 180

176. Section 402(a) of the Landrum-Griffin Act, 20 U.S.C. § 482(a) (1982), provides, in relevant part: "The challenged election shall be presumed valid pending a final decision ... and in the interim the affairs of the organization shall be conducted by the officers elected or in such other manner as [the union's] constitution and bylaws may provide." The Senate Report elaborated:

Since union business must not be brought to a standstill whenever an election is challenged, it is necessary to make some provison for the conduct of business while the proceeding is in progress. It would be intolerable for the Goverument to appoint outsiders to act as receivers. The choice lay between keeping the old officers in office or allowing the new officers to enter upon their duties....

Senate Comm. on Labor and Public Welfare, Labor-Management Reporting and DisCLOSURE ACT OF 1959, S. REP. No. 187, 86th Cong., 1st Sess. 22, reprinted in 1959 U.S. CODE CONG. \& ADMIN. NEws 2318, 2338, and in 1 LMRDA LEGISLATIVE HISTORY, supra note 66, at 418.

177. Landrum-Griffin Act § 402(b), 29 U.S.C. § 482(b) (1982).

178. Brennan v. American Guild of Variety Artists, 87 L.R.R.M. (BNA) 2607 (S.D.N.Y. 1974).

179. See Hall v. Cole, 412 U.S. 1, 10-13 (1973) (noting that the remedy provisions "cast as a broad mandate to the courts to fashion "appropriate relief' ").

130. Porter v. Warner Holding Co., 328 U.S. 395, 398 (1946); see also Califano v. Yamasaki, 442 U.S. 682, 705 (1979); Sullivan v. Little Hunting Park, Inc., 396 U.S. 229, 239 (1969); Jones v. Alfred H. Mayer Co., 392 U.S. 409, 414 n.13 (1968); Bell v. Hood, 327 U.S. 678, 684 (1946); Scripps-Howard Radio, Inc. v. FCC, 316 U.S. 4, 11 (1942). As the Supreme Court explained in a decision implying the availability of attorneys fees for prevailing plaintiffs under the LMRDA's union members' bill of rights:

Title I litigation necessarily demands that remedies "be tailored to fit facts and circumstances admitting of almost infinite variety," and $\S 102$ was therefore cast as a broad mandate to the courts to fashion "appropriate" relief. Indeed, any attempt on the part of Congress to spell out all of the remedies available under $\$ 102$ would create the "danger that those [remedies] not listed might be proscribed with the result that the courts would be fettered in their efforts to 'grant relief aceording to the necessities of the case.'"

Hall v. Cole, 412 U.S. 1, 11 (1972) (quoting Gartner v. Soloner, 384 F.2d 348, 353 (3d Cir. 1967)). 
True, in enacting Landrum-Griffin, Congress was guided by the general principle that a "union should be left free to "operate their own affairs, as far as possible;" " that union members " 'are fully coinpetent to regulate union affairs" "181 with only "minimum interference by Government." 182 But to the extent that view counsels against the use of intrusive equitable remedies, the fact that it appears in the legislative history before the addition on the Senate floor of the union members' bill of rights undercuts its force. Indeed, that view was put forward for the purpose of justifying the controversial onission froin the bill, as reported out of committee, of a umion meinbers' bill of rights. ${ }^{183}$ As finally enacted, Landrum-Griffin contemplates substantially more judicial interference with internal union affairs than the earhier versions described in the Senate reports. In any event, that courts should allow unions to run their own affairs "as far as possible" does not necessarily inean that the courts can never impose intrusive remedies such as receiverships; it may mean simply that they shonld use such drastic reinedies only as a last resort.

\section{Title VII and the Integration of Unions, Apprenticeship Programs, and Hiring Halls}

Whether permanent or temporary, the demise of the conimon law umion receivership a generation ago did not mean the end of union institutional reform litigation. In this decade, civil RICO has einerged as a modern, statutory basis for similar reinedies. In the interim years, title VII of the Civil Riglits Act of $1964^{184}$ served as an important substantive basis for the courts, often with the assistance of masters and receivers, to supervise the reform and day-to-day affairs of unions and related institutions, such as hiring halls and apprenticeship prograins.

Until the passage of the Civil Rights Act of 1964, labor unions had no legal obligation to admit minority or feinale inembers into their

ERISA, the pension reform statute of 1974, like Landrum-Griffin, contains broad remedial language but no express authorization for the appointment of receivers, and courts have construed it to authorize the judicial appointment of receivers to supervise the day-to-day affairs of pension and welfare funds. See infra text accompanying notes 214-36.

181. United Steelworkers v. Sadlowski, 457 U.S. 102, 117 (1981) (quoting S. REP. No. 1684, 85th Cong., 2d Sess. 4-5 (1958)).

182. S. REP. No. 187, 86th Cong., 1st Sess. 7 (1959), 1 LMRDA Legislative History, supra note 64 , at 403 .

183. See Levy, supra note 71 , at $684 \mathrm{n} .118$ ("The adoption on the floor ... of the LandrumGriffin substitute, amounts to a repudiation of this portion of Senate Report No. 187."); see generally Rothman, Legislative History of the "Bill of Rights" for Union Members, 45 MiNN.L. REv. 199, 213 (1960).

184. 42 U.S.C. $\$ \S 2000$ e to $2000 \mathrm{e}-17$ (1982 \& Supp. V 1987). 
ranks. ${ }^{185}$ Many unions had formal prohibitions against black menibership, and many others relegated black members to auxiliary or segregated locals. Unions without formal restrictions were able to exclude blacks or other minority group members by less formal means, such as requiring new members to be sponsored by present members, allowing proposed menibers to be blackballed by the votes of only a handful of incumbent members, or giving preference to the relatives of present members. These exclusionary practices were most prevalent among the craft umions, particularly in the building trades, where unions frequently controlled access to work. These unions could easily bar "undesirables" by excluding them from apprenticeship programs, by rigging journeyman examinations so that minority craftsmen would fail, or by simply refusing to dispatch minority workers from union-run hiring halls. ${ }^{186}$

All of these practices became unlawful with the passage of title VII, but of course, they did not end overnight. As with school desegregation, the courts discovered that smiple injunctions ordering the end of discriminatory practices were often insufficient, and that more intrusive forms of equitable rehef were necessary. For example, when previously segregated union locals were ordered merged, some courts imposed transitional structural reforms that assured outnumbered blacks an effective voice in the newly merged locals by allocating a set number of executive board seats and convention delegate positions to the menibers of each of the old locals. ${ }^{187}$

In the unionized sectors of industries such as construction, where union-run hiring halls generally distribute jobs ${ }^{188}$ and union-dominated apprenticeship programs limit access to skills training, ${ }^{189}$ title VII

185. See, e.g., Oliphant v. Brotherhood of Locomotive Firemen \& Enginemen, 262 F.2d 359, 363 (6th Cir. 1958) (holding that "[t]he Brotherhood is a private association, whose membership policies are its own affair, and this is not an appropriate case for interposition of judicial control"), cert. denied, 359 U.S. 935 (1959).

186. See generally P. Foner, ORganized Labor AND the Black Worker (2d ed. 1982); W. Gould, Black Workers in White Unions (1977); R. Marshall, The Negro aNd OrganIZED LABOR (1965).

187. See, e.g., Fluker v. Papermakers, Locals 265 and 940, 6 Fair Empl. Prac. Cas. (BNA) 92, 97 (S.D. Ala. 1972) (ordering transitional protection to newly merged locals by creating additional officer positions); English v. Seaboard Coast Line R.R., 4 Fair Empl. Prac. Cas. (BNA) 904 (S.D. Ga. 1972); Hicks v. Crown Zellerbach Corp., 310 F. Supp. 536, 538 (E.D. La. 1970) (upholding order temporarily allocating officer positions to members of former local for black employees). For a general discussion of more recent, voluntary programs along these lines, see Goldberg, Affirmative Action in Union Government: The Landrum-Griffin Act Implications, 44 Oнто ST. L.J. 649 (1983).

188. See Fick, Political Abuse of Hiring Halls: Comparative Treatment Under the NLRA and the LMRDA, 9 INDUS. REL. L.J. 339, 341-46 (1987); Rains, Construction Trades Hiring Halls, 10 LAB. L.J. 363, 367 (1959).

189. Although most apprenticeship programs are ostensibly run by joint union-management committees, it is common for the union representatives on those committees to dominate the process by which new apprentices are selected. See W. GouLD, supra note 186, at 285. 
decrees have compelled fundamental changes in the day-to-day operations of those institutions. For example, court orders have changed admissions criteria, ${ }^{190}$ the length and content of apprenticeship programs, ${ }^{191}$ and have eliminated or modified jonrneyman examinations; ${ }^{192}$ courts have ordered numerical goals and quotas for admission to apprenticeship programs and dispatch from hiring halls; ${ }^{193}$ and courts have imposed new dispatch procedures, as well as detailed recordkeeping requirements, on hiring halls. ${ }^{194}$ One court even ordered the creation of an entirely new apprenticeship program for minority trainees. ${ }^{195}$

In many of these cases, the courts have appointed masters or advisory committees to assist in the formulation and implementation of those remedies. ${ }^{196}$ In Local 28, Sheet Metal Workers v. EEOC, the Supreme Court expressly held that such appointments were within the remedial powers of the district conrts. ${ }^{197}$ In reaching that conclusion, the Court rejected the union's argument that the appoimtment of an administrator with "broad powers" to supervise the union's compliance with the court's remedial decrees constituted "an unjustifiable interference" with the union's "statutory right to self-governance": "While the administrator may substantially interfere with petitioners' membership operations, such 'interference' is necessary to put an end to petitioners' discriminatory ways." 198

190. See, e.g., Local 28, Sheet Metal Workers' Int'l Ass'n v. EEOC, 478 U.S. 421, $481-83$ (1986).

191. See, e.g., Pennsylvania v. Local 542, Int'1 Union of Operating Eng'rs, 502 F. Supp. 7, 13-14 (E.D. Pa. 1978), aff'd, 648 F. 2d 922 (3d Cir. 1981) (en banc), aff'd in part and rev'd in part on other grounds sub nom. General Bldg. Contractors Ass'n v. Pennsylvania, 458 U.S. 375 (1982).

192. See, e.g., Local 542, 502 F. Supp. at 14.

193. See, e.g., United States v. Ironworkers Local 86, 443 F.2d 544, 550-51 (9th Cir. 1971), cert. denied, 404 U.S. 984 (1971).

194. EEOC v. Int'1 Union of Operating Eng'rs, Locals 14 \& 15, 13 Fair Empl. Prac. Cas. (BNA) 1490, 1503-04 (S.D.N.Y. 1976).

195. Ironworkers Local 86, 443 F.2d at 552-53. For an analysis of the nature and effectiveness of the title VII remedies imposed upon building trades unions, including a particularly detailed discussion of Ironworkers Local 86, see W. GouLD, supra note 186, at 316-62.

196. See, e.g., Pennsylvania v. Local 542, Int'1 Union of Operating Eng'rs., 619 F. Supp. 1273, 1279 (E.D. Pa. 1985) ("monitor"); United States v. Local 638, Enter. Ass'n of Steam, Hot Water, Hot Water, Hydraulic Sprinkler, Pneumatic Tube, Compressed Air, Ice Machine, Air Conditioning and Gen. Pipefitters, 360 F. Supp. 979, 991 (S.D.N.Y. 1973), aff'd, 501 F.2d 622 (2d Cir. 1974) ("administrator"); United States v. Local 86, Int'1 Ass'n of Ironworkers, 315 F. Supp. 1202, 1249 (W.D. Wash. 1970) ("Advisory Committee"), aff'd, 443 F.2d 544 (9th Cir.), cert. denied, 404 U.S. 984 (1971). See generally Harris, The Title VII Administrator: A Case Study in Judicial Flexibility, 60 CORNELI L. REv. 53 (1974).

197. 478 U.S. 421,482 (1986).

198. Id. at 481-82. Earlier in the litigation, the court of appeals made the same point more forcefully: "While union self-government is desirable and is, indeed, an ideal to which the law aspires, ... our interest in union self-government cannot immunize Local 28 from the consequences of its actions. ... [I]t is necessary for a court appointed administrator to exercise day-to-day oversight 
In some hiring hall and apprenticeship cases, the courts have given their appointees responsibilities closely approaching those of receivers. For exaniple, after experiencing five years of the defendant union's failure to comply with a less drastic decree, the court in Pennsylvania $v$. Local 542, Operating Engineers appointed a "Hiring Hall Monitor" with "full authority to operate and oversee all features of the hiring halls." 199 In another case, an administrator was appointed for a five-year term and was given extensive powers that included the authority to "approve or reject the disposition of all applications for entry into tle Umions or their programs," to conduct a study of the umion's hiring hall procedures, and to "revise or change" such procedures in any manner necessary to achieve the decree's objectives. ${ }^{200}$

\section{State Regulation of Unions in the Longshore and Casino Industries}

Other statutes also have provided the substantive basis for the judicially supervised reform of imternal union affairs. For example, traditional receiverships have been imposed upon imsolvent unions pursuant to the federal bankruptcy laws. ${ }^{201}$ State statutes designed to curb rácketeering on the docks of New York larbor and in the casmos of Atlantic City have authorized another major form of imtervention: outright prohibitions against individuals with criminal backgrounds or associations from holding umion office.

In 1953, in response to revelations of extensive corruption on both the New York and New Jersey sides of the Port of New York, the two states, with congressional approval, entered into an interstate compact to regulate waterfront employment that was aimed at keeping labor racketeers out of the longshore industry. ${ }^{202}$ Each state implemented the compact with legislation that prohibited imdividuals who had been convicted of certain crimes, and not subsequently pardoned or cleared by a

of the union's affairs." EEOC v. Local 638, Sheet Metal Workers Int'l Ass'n, 532 F.2d 821, 829 (2d Cir. 1976).

199. 619 F. Supp. 1273, 1277 (E.D. Pa. 1985). The court made crystal clear that the monitor was "responsible for running the day-to-day operations of the hiring hall." Id. at 1279.

200. EEOC v. Local 14, Int'1 Union of Operating Engr's, 13 Fair Empl. Prac. Cas. (BNA) 1490, 1495 (S.D.N.Y. 1976).

201. See, e.g., Highway and City Freight Drivers, Local 600 v. Gordon Transports, Inc., 576 F.2d 1285, 1287 (8th Cir. 1978) (holding that a union is a "person" under the Bankruptcy Act and thus can file for voluntary bankruptcy); In re Lane County Sheriff's Officers Ass'n, 16 Bankr. 190, 191 (D. Oregon 1981) (suit brought by trustee of a bankrupt labor union).

202. N.Y. Laws 1953, chs. 882, 883; N.J. Laws 1953, chs. 202, 203; Congressional approval appears in Act of Aug. 12, 1953, Pub. L. No. 83-252, 67 Stat. 541 (not codified). See DeVeau v. Braisted, 363 U.S. 144, 147-50 (1960). See generally V. JENSEN, supra note 108, at 116-20. (bi-state compact required registration of longshoremen and government supervision of employee selection). 
parole board, from holding office in unions representing waterfront employees. ${ }^{203}$

A quarter century later, when it legalized casino gambling in Atlantic City, the state of New Jersey enacted similar legislation intended to prevent organized crime infiltration of the casino industry and to ensure public trust in the industry's integrity. ${ }^{204}$ Like the New York and New Jersey waterfront statutes, the Casino Control Act prohibits individuals convicted of certain crimes froin holding office $\mathrm{n} 1$ unions representing einployees in the mdustry. ${ }^{205}$ The Act also disqualifies from union office individuals identified as members of "career offender cartel[s]," or even as mere associates of career offenders, or career offender cartels, if there is a "reasonable behef that the association is . . . inimical to the policy of [the] act."206

Both the New York Waterfront Coinmission Act and the New Jersey Casino Control Act have survived challenges in the U.S. Supreine Court, which rejected arguments that the two state regulatory schemes were preempted by the National Labor Relations Act and the LandruinGriffin Act.207 As the Court explained:

[A]t least where the States were confronted with the "public evils" of "crime, corruption, and racketeering," more stringent state regulation of the qualifications of union officials [is] not incompatible with ... . national labor policy. ... Both statutes form part of comprehensive programs designed to "vindicate a legitimate and compelling state interest, namely, the interest $m$ combating local crime infesting a particular industry." 208

To eliminate any doubt about its agreenent with the Court's resolution of these preemption questions, Congress expressly incorporated the Court's holding into its Comprehensive Crime Control Act of 1984.209

The Court left open, however, the question whether the officer disqualification provisions could be enforced by cutting off the offending

203. Waterfront Commission Act of $1953 \S 8$, (as amended), N.J. STAT. ANN. $\$ \S 32: 23-80$, 32:23-80.2 (West 1963); Waterfront Commission Act of $1953 \S 8$, N.Y. Laws 1953, cc. 882, 883, McKinney's Unconsol. Laws, \$ 6700aa.

204. Casino Control Act, N.J. STAT. ANN. $\S ~ 5: 12-1$ to -190 (West 1988). See generally Cohen, The New Jersey Casino Control Act: Creation of a Regulatory System, 6 SETON HALl LEGIS. J. 1 (1982); Lee \& Chelius, Government Regulation of Labor-Management Corruption: The Casino Industry Experience in New Jersey, 42 INDUS. \& LAB. REL. REv. 536 (1989); O'Brian \& Flaherty, Regulation of the Atlantic City Casino Industry and Attempts to Control Its Infiltration by Organized Crime, 16 Rutgers L.J. 721 (1985).

205. N.J. STAT. ANN. $\S \S 5: 12-86(c), 5: 12-93(b)$ (West 1988).

206. Id. $\S 5: 12-86(f)$.

207. See Brown v. Hotel \& Restaurant Employees Int'1 Union Local 54, 468 U.S. 491, 492 (1984) (Casino Control Act); De Veau v. Braisted, 363 U.S. 144, 155-56 (1960) (Waterfront Commission Act).

208. Brown, 468 U.S. at 508-09 (citations omitted).

209. 29 U.S.C. $§ 524 a$ (1982 \& Supp. V 1987). 
union's dues income. It acknowledged the risk that such a reinedy could so incapacitate a union as to prevent it from functioning as a union at all, but noted that sanctions imposed directly on the disqualified individuals, rather than their umions, would not have that effect. ${ }^{210}$ Both New Jersey statutes, and the New York statute as amended in 1969, authorize these remedial alternatives. ${ }^{211}$

The Casino Control Act and the two waterfront commission statutes also have survived first amendinent challenges. State and federal courts have held that the three statutes' officer disqualification provisions do not violate the associational rights of either the unions, their ineinbers, or the disqualified individuals themselves ${ }^{212}$-an issue to which this Article will later return. ${ }^{213}$

\section{E. The Reform of Union Pension and Welfare Funds}

The Employee Retirement Income Security Act of 1974 (ERISA) ${ }^{214}$ which regulates the operation of employee pension and welfare funds, provides another substantive basis for institutional reform litigation that can affect the internal affairs of unions. ${ }^{215}$ Like construction industry apprenticeship programs, ${ }^{216}$ collectively bargained benefit plans are ostensibly operated jointly by labor and inanageinent, but as with apprenticeship programs, the union trustees often dommate fund operations. ${ }^{217}$ Because union designated benefit fund trustees typically hold

210. Brown, 468 U.S. at 510-12.

211. See N.J. STAT. ANN. § 5:12-93(d)(e) (West 1988); id. § 32:23-80.2 (West 1963); 1969 N.Y. LAws ch. 951, §1.

212. For decisions upholding provisions of the New Jersey Casino Control Act, see Hotel and Restaurant Employees Int'l Union Local 54 v. Read, 832 F.2d 263, 266 (3d Cir. 1987); In re Martin, 90 N.J. 295, 336, 447 A.2d 1290, 1311 (1982); In re Hotel and Restaurant Einployees Local 54, 203 N.J. Super. 297, 297, 496 A.2d 1111, 1112 (App. Div.), certif. denied, 102 N.J. 352, 508 A.2d 223 (1985), cert. denied, 475 U.S. 1085 (1986). For decisions reviewing provisions of the New York Waterfront Commission Act, sec Local 1814, Int'1 Longshoreınen's Ass'n v. Waterfront Coinın'n, 667 F.2d 267, 273-74 (2d Cir. 1981); International Longshoreinen's Ass'n v. Waterfront Coinm'n, 642 F.2d 666, 669-71 (2d Cir. 1981). On the constitutionality of the disqualification provision of the New Jersey Waterfront Comınission Act, see Hazelton v. Murray, 21 N.J. 115, 115, 121 A.2d 1, 1 (1956) (Brennan, Win., J.).

213. See infra text accompanying note $342-61$.

214. 29 U.S.C. $\S \S 1001-1461$ (1982 \& Supp. V 1987).

215. Even before ERISA, courts asserted their inherent equitable powers to impose receiverships on pension funds, see, e.g., Hurd v. Hutnik, 419 F. Supp. 630, 636 n.1, 662 (D.N.J. 1976), and to remove corrupt benefit plan trustees and order the new trustees to retain independent professional investinent counselors, see, e.g., Blankenship v. Boyle, 329 F. Supp. 1089, 1113 (D.D.C. 1971), aff'd, 511 F.2d 447 (D.C. Cir. 1975).

216. See supra note 189.

217. Before its cleanup, for example, trustees appointed by the union called the tune in the giant, corruption-ridden Teamsters Central States pension fund. See S. BRILI, supra note 1, at 203. 
high union offices, ${ }^{218}$ judicially imposed changes in fund administration can substantially affect a union's internal political climate.

The most common forms of corruption in pension and welfare plans involve the abuse of plan funds for personal gain, either through direct self-dealing or through kickbacks received in exchange for improperly investing plan funds or contracting with unscrupulous service providers. ${ }^{219}$ Not surprisingly, such conduct violates the fiduciary duties imposed on plan officials by ERISA. ${ }^{220}$ The statute's enforcement scheme provides the Secretary of Labor and plan participants and beneficiaries with broad, flexible remedies to redress or prevent statutory violations. ${ }^{221}$ Although ERISA does not expressly authorize the appointment of receivers to take over the adininistration of benefit plans that have been victimized by fiduciary violations, courts have construed its language, which provides for "such other equitable or remedial relief as the court may deem appropriate, including removal of . . f fiduciar[ies],"222 to permit such receiverships. 223

Perhaps the leading example of ERISA's use in the battle against pension fund corruption is its role in cleaming up the giant Teamsters Central States, Southeast, and Southwest Areas Pension Fund, the largest multi-employer pension fund in the country. ${ }^{224}$ Once dubbed "the most abused, misused pension fund in America," 225 the Central States fund was for much of its existence "the mob's bank," where "loans depended alınost always on the right kickbacks or the right organizedcrime connections." 226 According to one estimate, the fund's losses, due

218. In the Teamsters Central States fund, for example, past trustees have included Teamsters General Presidents Jimmy Hoffa, Frank Fitzsimmons, Roy Williams, and Jackie Presser. Id. at 115.

219. See supra text accompanying notes $37-42$.

220. 29 U.S.C. $\$ \S 1104,1106$ (1982).

221. Id. $\S 1132$ (1982 \& Supp. V 1987).

222. Id. $\S 1109$ (a).

223. See, e.g., Marshall v. Snyder, 572 F.2d 894, 901 (2d Cir. 1978) (appointment of receivership proper in view of union officers' conflict of interest); Donovan v. Robbins, 558 F. Supp. 319, 329 (N.D. Ill.) (receivership is a proper remedy where serious fiduciary violations have occurred), aff'd sub nom. Donovan v. Dorfman, 703 F.2d 570 (7th Cir. 1983); Donovan v. Bryans, 566 F. Supp. 1258, 1264 (E.D. Pa. 1983) (Secretary of Labor may seek a receiver in appropriate circumstances); see also Donovan v. Mazzola, 716 F.2d 1226, 1238-39 (9th Cir. 1983) (upholding the court appointment of an investment manager to control fund's investments for ten year-period).

224. The fund has 400,000 participants and beneficiaries and assets totalling over $\$ 8$ billion. Teamsters Pension Fund Accord, N.Y. Times, Nov. 11, 1987, at A27, col. 1.

225. Cook, The Most Abused, Misused Pension Fund in America, ForBes, Nov. 10, 1980, at 69.

226. S. BRILL, supra note 1, at 201, 215. Teamster reformers sometimes joke that IBT conventions are held in Las Vegas so that delegates can see how their pension funds have been invested. It's no joke: millions of dollars in Central States' loans, often to front-men for organized crime, financed construction of several large Las Vegas casinos and hotels. See id. at 210-16. Collateral for one such loan was $\$ 5$ million in gambler's IOU's. See id. at 117. 
to loans repaid at below-market interest rates or never repaid at all, amounted to $\$ 385$ million. ${ }^{227}$

Not surprisingly, one of Jimmy Hoffa's criminal convictions was for pension fund abuse involving the Central States fund. ${ }^{228}$ But that conviction no inore led to the cleanup of the Central States pension fund than it did to the cleanup of the Teamsters union itself. Another decade would pass before the Internal Revenue Service and the Departinent of Labor (DOL), relying on ERISA and a threat to revoke the fund's tax exempt status, ${ }^{229}$ successfully pressured Hoffa's successors into initiating basic reforms in the fund's operations. A inajority of the fund's trustees, including IBT President Frank Fitzsimnions, agreed to resign in late 1976 and early 1977, and independent asset managers were brought in for a five-year term. ${ }^{230}$ Unfortunately, those reforms, which had not been einbodied in an enforceable consent decree, proved inadequate. The new fund trustees soon stopped cooperating with further DOL investigations and also began to undermine the independence of the new asset nianagers. ${ }^{231}$

In September, 1982, in the face of severe criticism from the General Accounting Office and a Senate subcornmittee that it had bungled a inajor opportunity for cleaning up the fund, ${ }^{232}$ the DOL negotiated a new agreement with the Central States fund which appears to have finally expunged any reniaining corrupting influences. ${ }^{233}$ Partially settling a DOL ERISA action filed in 1978, the consent decree extended the independent managenent of the fund's assets for at least another ten years and increased the barriers against efforts by the trustees to undermine that independence. The decree also provided for the appointinent of an

227. Id. at 255 .

228. See D. MoLDEA, supra note 7, at 173-74.

229. The IRS in fact had charged ahead on its own, without coordinating its efforts with either the Labor or Justice Departments, and had ordered the fund's tax exempt status revoked in June of 1976. See OVERSight INQUiRY OF THE DEPARTMENT OF LABOR's INVESTIGATION OF THE TEAMSTERS Central States Pension Fund, S. Rep. No. 177, 97th Cong., 1st Sess. 18 (1981) [hereinafter OVERSIGHT INQUIRY]. The revocation was never actually implemented, however, see id. at $164-65$, because, as the "atomic weapon" of pension reform, it would have punished not only the trustees but also innocent participants and employers as well. The IRS thus found itself "scrambling around trying to find a way out of it." Id. at 24 (quoting Senator Sam Nunn).

230. See id. at 61-62; S. BRILL, supra note 1, at 114-20.

231. The DOL had no role in selecting the trustees. See OVERSIGHT INQUIRY, supra note 229, at $62-76,167-68$.

232. See General Accounting Office, Investigation to Reform Teamsters' Central States Pension Fund Found INADEQUATE (1982); OVERSight InQUiRY, supra note 229.

233. See Proposed Consent Decree, Donovan v. Fitzsimmons, No. 78-C-342 (N.D. Ill. Sept. 21, 1982), reprinted in Daily Lab. (BNA), Sept. 21, 1982, at F-1. [hereinafter Consent Decree]; see Cook, Going Sraight, Forbes, May 19, 1986, at 51; Geisel, ERISA Prompts Cleanup of Teamsters Plan, Bus. INS., Aug. 27, 1984, at 3. 
"independent special counsel" to assist in identifying and resolving any problems or issues that might arise in connection with the fund's performance of its obligations under the decree or under ERISA. ${ }^{234}$ The decree did not waive any of the DOL's monetary claims against the fund's former trustees.

In late 1987, a final settlement of the Central States litigation extended the terms of the 1982 decree until at least the year 2002, with a possible extension to 2007. Moreover, it provided for a judicial veto over any appoimtments of new pension fund trustees, as well as a monetary settlement in excess of $\$ 4$ million to be paid to the fund by the former trustees or their estates. ${ }^{235}$ After a decade of institutional reform litigation pursuant to ERISA, the Teamsters Central States pension fund appears to be one of the best managed multi-employer plans in the country. ${ }^{236}$

\section{The Civil Rico Structural InJunction}

The Racketeer Influenced and Corrupt Organizations Act 237 is not primarily a labor statute, but combating organized crime's infiltration of the labor movement was one of its central legislative goals. ${ }^{238}$ For this reason, many of the controversies which have been associated with criminal and civil RICO in other contexts ${ }^{239}$ are less relevant to the statute's labor apphications. For example, whether RICO's reach is limited to defendants with actual organized crime connections has not been an issue

234. Consent Decree, supra note 233. Former U.S. Attorney General William B. Saxbe was named independent special counsel shortly thereafter. See Former Attorney General Saxbe Named to be Counsel to Central States Fund, 9 Pen. Rep. (BNA) 1784 (1982).

235. Whitfield v. Fitzsimmons, No. 78-C-342 (N.D. Ill. Nov. 10, 1987). See also Labor Department Settlement of Central States Case Is Approved, 14 Pen. Rep. (BNA) 1500 (1987) (discussing Whitfield).

236. See Cook, supra note 233, at 51. But see "Trustees Report" Fails to Tell Full Story, ConvoY Dispatch, Mar. 1989, at 6 (criticizing trustees for keeping benefits too low and eligibility requirements too high).

237. 18 U.S.C. $\S \S 1961-68$ (1982 \& Supp. V 1987). RICO was enacted as title IX of the Organized Crime Control Act of 1970, Pub. L. No. 91-452, § 1, 84 Stat. 922, 922.

238. See Pub. L. No. 91-452, $\S 1,84$ Stat. 922, 922 (Statement of Findings and Purposes, noting organized crime infitration and corruption of legitimate businesses and labor unions); S. REP. No. 617, 91st Cong., 2d Sess. 35, 78 (1970) (same); 115 Cong. Rec. 5874 (1969); 116 Cong. Rec. 585 (1970) (remarks of Senator McClellan, RICO's chief sponsor in the Senate-the same Senator McClellan who chaired the Senate's investigation of labor racketeering in the late 1950's and who was a key supporter of the Landrum-Griffin Act).

239. See, e.g., Mansnerus, As Racketeering Law Expands, So Does Pressure to Rein It In, N.Y. Times, Mar. 12, 1989, § 4, at 4; Pickholz, The Firestorm Over Civil RICO, 71 A.B.A. J., Mar. 1985, at 79. 
in many union reform cases, where Mafia infiltration of the labor inoveinent is precisely the problein being addressed. ${ }^{240}$ Similarly, the criticism that an aggressive plaintiff's bar has exploited civil RICO to make trebledamage mountains out of garden-variety fraud inolehills, ${ }^{241}$ and that civil RICO should be limited to defendants who have been convicted of the underlying predicate acts, ${ }^{242}$ is not applicable to cases in which union officials have, in fact, been convicted of violently extorting union ineinbers' rights, embezzhing union funds, or taking payoffs from employers. ${ }^{243}$ One leading critic of the expansive reading that inany courts have given RICO in the criminal context even goes so far as to say that "in the labor cases ... RICO actually operates to a considerable extent as advertised."244

On the other hand, RICO's application in the labor relations context has generated a new set of issues and controversies all its own. ${ }^{245}$ This section will analyze civil RICO union reform litigation in light of such

240. See, e.g., United States v. Local 560, Int'l Bhd. of Teamsters (Local 560 III), 780 F.2d 267, 284 (3d Cir. 1985) (infiltration by Genovese organized crime family), cert. denied, 476 U.S. 1140 (1986); United States v. Local 30, Umited Slate, Tile \& Composition Roofers, 686 F. Supp. 1139, 1141-63 (E.D. Pa. 1988) (infiltrated by associates of Philadelphia Mafia boss Nicodemo Scarfo); United States v. Local 6A, Cement and Concrete Workers, 663 F. Supp. 192, 193 (S.D.N.Y. 1986) (infiltration by Colombo organized crime family).

Although eradicating organized crime was one of the principal purposes behind RICO, constitutional prohibitions against making Mafia membership a "status crime" necessitated a broadly written statute which Congress knew would reach far beyond the criminal underworld. As Senator McClellan explained, "It is impossible to draw an effective statute which reaches most of the commercial activities of organized crime, yet does not include offenses commonly committed by persons outside organized crime as well." 116 CONG. REC. 18,940 (1970). The courts, therefore, have almost uniformly rejected efforts to so limit the statute. See, e.g., Sedima, S.P.R.L. v. Imrex Co., 473 U.S. 479, 499 (1985); Alcom County v. U.S. Interstate Supples, Inc., 731 F.2d 1160, 1167 (5th Cir. 1984) (citing other courts in agrecment).

241. See, e.g., 1985 A.B.A. Sec. Corp., Report of the Ad Hoc Civil RICO Task Force 56-57 (Mar. 28, 1985).

242. Since the Supreme Court's rejection of the argument that a defendant's prior conviction is an essential element of the civil RICO cause of action, see Sedima, 473 U.S. at 493, repeated efforts have been made to amend the statute to impose such a requirement. See, eg., Justice Department Backs Limits on Civil Racketeer Suits, N.Y. TrMEs, Sept. 24, 1986, at A17, col. 1.

243. See, e.g., Local 560 III, 780 F.2d at 273-74, 283 (umion officials extortion of "labor peace payments" and kickbacks from a number of employers; extortion of members' Landrum-Griffin rights); Local 30, 686 F. Supp. at 1165-66 (over twenty year period leaders of Roofers Umion utilized threats and violence against members and non-union contractors).

244. Lynch, RICO: The Crime of Being a Criminal (pts. 1 \& 2), 87 CoLum. L. REv. 661, 758 (1987). For an overview of RICO's application to labor racketeering, see Blakey \& Goldstock, supra note 33 .

245. For discussion of some of these controversies, see Engelstein, Racketeer Influenced and Corrupt Organizations Act: Uninvited Guest at the Collective Bargaining Table?, 38 NAT'L Conf. ON LABOR Proc. 10-1 (1985); Shepard, Horn \& Duston, RICO and Employment Law, 3 LABOR LAW. 267 (1987); Tarantola, An Analysis of the Potential Use of RICO to Impede the Flow of Runaway Shops, 3 HofsTRA LAB. L.J. 205 (1986); Note, The Exclusive Jurisdiction of the NLRB as a Limitation on the Application of RICO to Labor Disputes, 76 KY. L.J. 201 (1987-88). 
fundamental labor law concerns as preemption and the NorrisLaGuardia Act's limitation on the role of the federal courts in labor disputes. ${ }^{246}$ It also will suggest an approach for resolving the potential conflicts between intrusive RICO remedies and the associational rights of umions and their members, rights embodied in the Landrum-Griffin Act's umion members' Bill of Rights ${ }^{247}$ and in the first amendment itself. Before reaching those issues, however, it will describe civil RICO's operation and the broad range of remedies it contemplates.

\section{A. Civil RICO}

RICO's civil cause of action provides the most important contemporary basis for the judicially supervised reform of corrupt labor unions. Pursuant to RICO's core substantive provisions, a person ${ }^{248}$ violates the Act if he or she (a) uses income from a "pattern of racketeering activity" to acquire an interest im an "enterprise"; (b) acquires an interest in an enterprise directly through a pattern of racketeering activity; (c) conducts or participates in the operation of an enterprise through a pattern of racketeermg activity; or (d) conspires to commit any of the foregoing violations. ${ }^{249}$ "Enterprise" has a broad definition, ${ }^{250}$ and in the labor context, the relevant enterprise would typically be a union, an employer, or a pension or benefit fund.

A "pattern of racketeering activity" consists of the commission of two or more predicate acts of racketeermg activity within a ten-year period. ${ }^{251}$ "Racketeering activity" is defined by reference to a long list of state and federal crimes ranging from murder and arson to securities fraud and bribery ${ }^{252}$ - a list of predicate acts that expressly includes three labor crimes. ${ }^{253}$ While the nature of the pattern which the predicate acts

246. See infra text accompanying notes 301-41.

247. 29 U.S.C. $\S 411$ (1982).

248. "Persons" under the Act can be entities such as unions and employers, as well as individuals. 18 U.S.C. $\S 1961(3)$ (1982 \& Supp. V 1987).

249. Id. § 1962(a)-(d).

250. See id. § 1961(4).

251. Id. § 1961(5).

252. Id. § 1961(1). Mail and wire fraud are two of RICO's more controversial predicate offenses, because they bring many "garden variety" cases of fraud within the statute's reach. See supra text accompanying note 241 .

253. These are embezzlement of union funds, 29 U.S.C. § 501(c) (1982); embezzlement of pension and welfare funds, 18 U.S.C. $\S 664$ (1982); and illegal payments to labor unions and bribery of union officials, 29 U.S.C. § 186 (1982). See 18 U.S.C. § 1961(1) (1982 \& Supp. V 1987) (incorporating these labor offenses into RICO). Extortion of membership rights as a RICO predicate act is addressed infra at text accompanying notes 263-300. 
must establish lias been a continuing source of controversy in other contexts, ${ }^{254}$ in the civil RICO union reform cases decided thus far, the number of and the relationships among the predicate acts lave been extensive enough to meet even the most demanding standards. ${ }^{255}$

In addition to providing a treble damages remedy to the victims of RICO violations, ${ }^{256}$ the statute's civil provisions authorize the courts to issue a wide range of equitable rehef, including bans against further participation in the affairs of corrupt unions by the individuals responsible for their corruption. ${ }^{257}$ Statutory language expressly authorizing the courts to order "the reorganization" of corrupt enterprises demonstrates that Congress intended civil RICO to serve as a substantive basis for institutional reform litigation. ${ }^{258}$

The autlority "to reorganize" a corrupt enterprise, together with the courts' inherent equitable powers ${ }^{259}$ and Congress's explicit instructions that RICO 'be liberally construed to effectuate its renredial

254. In H. J. Inc., v. Northwestern Bell Tel. Co., 109 S. Ct. 2893, 2906 (1989), the Supreme Court endorsed a broad concept of "pattern" in the civil RICO context. See also Blakey \& Cessar, Equitable Relief Under Civil RICO: Reflections On Religious Technology Center v. Wollersheim: Will Civil RICO Be Effective Only Against White-Collar Crime?, 62 NOTRE DAME L. REv. 526, 53540 (1987) (discussing district court failure to follow Supreme Court initiative in developing consistent definition of pattern in Sedima); Goldsmith, Civil RICO Reform: The Basis for Compromise, 71 MINN. L. REv. 27, 843 \& n.69 (1987) (broad definition of "pattern" by certain district courts encourages undesirable forum-shopping, so a more consistent defintion should be created); Note, Clarifying a "Pattern" of Confusion: Multi-Factor Approach to Civil RICO's Pattern Requirement, 86 MicH. L. REv. 1745 (1988) (courts' definition of "pattern" should consider number of victims injured, duration of activity, number of separate transactions, and source of multiple and distinct criminal decisions).

255. See United States v. Local 560, Int'1 Bhd. of Teamsters (Local $560 \mathrm{III}$ ), 780 F.2d 267 (3d Cir. 1985), cert. denied, 476 U.S. 1140 (1986); United States v. Local 30, United Slate, Tile \& Composition Roofers, 686 F. Supp. 1139, 1165 (E.D. Pa. 1988).

256. 18 U.S.C. $\S 1964$ (c) (1982 \& Supp. V 1987). For a discussion of the relationship between RICO's treble damages remedy and the "union members derivative action" created by title $\mathrm{V}$ of the Landrum-Griffin Act-and the availability of a "hybrid RICO/section 501" cause of action, sec supra text accompanying notes 74-76; infra text accompanying notes 333-37.

257. 18 U.S.C. $\S 1964$ (a) (1982).

258. Id. As RICO's floor manager in the House explained, "Courts are given broad powers ... to proceed civilly, using essentially their equitable powers, to reform corrupted organizations." 116 CONG. REC. 35,295 (1970) (remarks of Cong. Richard H. Poff) (emphasis added). The statute even gives RICO courts the authority to dissolve corrupt enterprises:

The district courts of the United States shall have jurisdiction to prevent and restrain [RICO] violations ... by issuing appropriate orders, including, but not limited to: ordering any person to divest himself of any interest, direct or indirect, in any enterprise; imposing reasonable restrictions on the future activities or investments of any person, including, but not limited to, prohibiting any person from engaging in the same type of endeavor as the enterprise engaged in ... or ordering dissolution or reorganization of any enterprise, making due provision for the rights of innocent persons.

18 U.S.C. § 1964(a) (emphasis added).

259. Nothing in the statute or its legislative history suggests that Congress intended to limit the courts' traditional range of equitable remedies. As the Supreme Court has repeatedly held, "Unless 
purposes," 260 leave hittle doubt that courts have the power to issue structural injunctions in labor racketeering cases, including orders imposing trusteeships upon racketeer-ridden unions. ${ }^{261}$ As the legislative history makes clear, RICO's hist of remedies "is not ineant to be exhaustive. ... [T] he only limit on remedies is that they accoinplish the ain set out of removing the corrupting influence and make due provisions for the riglits of innocent persons." 262

In the labor setting, "mak[ing] due provisions for the rights of innocent persons" requires accommodating RICO remedies to the organizational and collective bargaining rights guaranteed workers by federal labor law, and to the associational rights guaranteed unions and their members by the first amendment. Before addressing those reinedial concerns, however, we turn to an important substantive issue that has arisen in a number of union reform cases: whether aiding and abetting the extortion of membership rights is a RICO predicate act.

\section{B. Aiding and Abetting the Extortion of Membership Rights}

When government prosecutors first souglit to explore tlie full reach of RICO's civil reinedies in their fight against labor racketeering in Tony Provenzano's Teamsters Local 560, their goal was to remove from office Local 560's entire seven member executive board and to replace them with a court-appointed trustee to run the union's affairs until sucl time as fair elections could be held. ${ }^{263}$ By the time the court iniposed the trusteeship, however, neither Tony Provenzano nor any of lis brothers

otherwise provided by statute, all the inherent equitable powers [of the court] are available." Porter v. Warner Holding Co., 328 U.S. 395, 398 (1946). See supra text accoinpanying notes 117-33.

260. Pub. L. No. 91-452, § 904(a), 84 Stat. 922, 947 (1970); see also Sedima, S.P.R.L. v. Imrex Co., 473 U.S. 479, 497-98 (1985) (Congress's "self-consciously expansive language" and express admonition that "RICO is to be "liberally construed" " dictate the conclusion that RICO is to be read broadly); Russello v. United States, 464 U.S. 16, 27 (1983) ("tlie legislative history clearly demonstrates that the RICO statute was intended to provide new weapons of unprecedented scope for an assualt upon organized crime and its economic roots").

261. Further support for this conclusion can be found in the fact that RICO's civil provisions were modeled in part on those of the antitrust statutes, see Sedima, 473 U.S. at 486-90, and judicial authority to impose corporate receiverships to enforce the antitrust laws has been recognized for over seventy-five years. See United States v. American Tobacco Co., 221 U.S. 106, 186, 188 (1911). Senator McClellan may have had precisely these receiverships in inind when he explained, "[S]ince enactinent of the Sherman Antitrust Act in 1980, the courts have used several equitable remedies. . . . I believe, and numerous others have expressed a similar belief, that these equitable devices can prove effective in cleaming up organizations corrupted by the forces of organized crime." 116 CONG. REC. 592 (1970).

262. H. R. REP. No. 1549, 91st Cong., 2d Sess. 57 (1970). Similarly, Senator McClellan explained that RICO is not "limit[ed] [to] the remedies . . . already ... established. The ability of our chancery courts to formulate a remedy to fit the wrong is one of the great benefits of our system of justice." 115 CoNG. Rec. 9567 (1969).

263. See infra text accompanying notes $364-74$. 
or associates who liad been directly implicated in murders and beatings of umion rivals, embezzlement, or receipt of employer payoffs, were serving on the union's executive board.264 Three of the seven board members, in fact, did not loold their positions when most of tle predicate acts underlying the lawsuit occurred. ${ }^{265}$ How then did the Local 560 court justify its removal from office of those "executive board defendants"?

The court first lield that "aiding and abetting" the commission of a RICO predicate offense is itself a predicate offense. ${ }^{266}$ A clear consensus in the courts supports that conclusion, ${ }^{267}$ as does RICO's hiberal construction clause. ${ }^{268}$ While the list of offenses that constitute "racketeering activity" does not expressly include aiding and abetting, ${ }^{269}$ nothing im the legislative history suggests that Congress intended to place RICO violations beyond the normal reach of the federal aiding and abetting statute, ${ }^{270}$ which apphes to all federal crimes. ${ }^{271}$

The district court found that the executive board defendants had aided and abetted the Provenzanos and the other individual defendants in the creation of "a clinate of intimidation" which "induce[d] or coerce[d] the membership into surrendering their federally protected rights

264. See United States v. Local 560, Int'l Bhd. of Teamsters (Local 560 III), 780 F.2d 267, 274 (3d Cir. 1985), cert. denied, 476 U.S. 1140 (1986).

265. See id. 780 F.2d at 288 .

266. Id. at 288 n.25.

267. See, e.g., Petro-Tech, Inc. v. Western Co., 824 F.2d 1349, 1356-57 (3d Cir. 1987); United States v. Wyatt, 807 F.2d 1480, 1482 (9th Cir. 1987); United States v. Cauble, 706 F.2d 1322, 1334, 1339 (5th Cir. 1983); United States v. International Bhd. of Teamsters, 708 F. Supp. 1388, 1401 (S.D.N.Y. 1989); Rodonich v. House Wreckers Union, Local 95, 627 F. Supp. 176, 180 (S.D.N.Y. 1985); Laterza v. American Broadcasting Co., 581 F. Supp. 408, 412 (S.D.N.Y. 1984).

268. See supra notes 260-62 and accompanying text.

269. 18 U.S.C. $\S 1961$ (1) (1982 \& Supp. V 1987). Perhaps it was omitted because aiding and abetting can best be understood not as a discrete criminal offense but simply as a means of identifying the nature of a given defendant's involvement in the substantive offense. See United States v. Oates, 560 F.2d 45, 54 (2d Cir. 1977). If so, the maxim expressio unius est exclusio alterius (the express inclusion of some itents implies the exclusion of others) would have little application to this question of statutory interpretation.

270. The aiding and abetting statute, 18 U.S.C. $\$ 2$ (1982), provides: "(a) Whoever commits an offense against the United States or aids, abets, counsels, commands, induces or procures its commission, is punishable as a principal." The defendant need not commit all the elements of the substantive offense so long as she assists in some nanner with its commission with the requisite crininal intent. See, e.g., United States v. Fischel, 686 F.2d 1082 (5th Cir. 1982).

271. See United States v. Lennon, 751 F.2d 737, 741 (5th Cir. 1985) (federal statute applies to all federal crintes and "prohibits one from causing another to do any act that would be illegal if one did it personally"), cert. denied, 471 U.S. 1100 (1985); United States v. Jones, 678 F.2d 102, 105 (9th Cir. 1982) ("The aiding and abetting provision of 18 U.S.C. $\$ 2 \ldots$ is applicable to the entire criminal code."); Note, Aiding and Abetting the Investment of Dirty Money: Mens Rea and the Nonracketeer Under RICO, Section 1962(a), 82 ColUM. L. REv. 574, 583 (1982) (Congress did not intend to abandon "normal criminal law principles and preclude the conviction of nonracketeers as aiders and abettors or coconspirators."). 
to participate in the affairs of Local 560 in a deinocratic manner."272 The "Provenzano Group" had created that climate of intinidation with the repeated use of actual or threatened violence, exemplified by the murders of Provenzano opponents in 1961 and $1963^{273}$ and the "roughing up" of another Provenzano critic in 1983 while the trial was in progress. ${ }^{274}$ The Provenzano group also spawned fear that opposition to or criticisin of the union's leadership could result in "disastrous and irreparable economic harm,"275 "particularly the loss of the ability to earn a hivelihood."276

The court determined that the executive board defendants assisted the Provenzano Group in creating that atmosphere in a variety of ways: the repeated appointinent of convicted crininals within that group to positions of trust within the local, 277 the failure to remove corrupt appointees from office, ${ }^{278}$ and the authorization of increased salary and pension benefits for Tony Provenzano after he had committed three criminal offenses while a inember of the executive board.279 Moreover, given that title $V$ of the Landrum-Griffin Act imposes an affirmative duty upon union officials to act on the nembership's behalf, 280 the court concluded that the executive board defendants' reckless indifference to the Provenzano Group's systematic misconduct was itself evidence of an intent to aid and abet the misconduct. ${ }^{281}$

272. United States v. Local 560, Int'l Bhd. of Teamsters (Local 560 I), 58I F. Supp. 279, 284-85, 312 (D.N.J. 1984), aff'd, 780 F.2d 267 (3d Cir. 1985), cert. denied, 476 U.S. 1140 (1986). One measure of the effectiveness of the defendants' campaign of intimidation, according to the court and the government's expert witness, Professor Clyde Summers, was "the complete absence of publicly voiced opposition to, disagreement with or critical discussion of the [non-contract related] policies, proposals, decisions and actions of the Provenzano Group incumbents." Local 560 I, 581 F. Supp. at 316.

273. Although the court found the evidence insufficient to conclude that Provenzano or his associates had actually ordered or committed the second murder, it did find that "Glockner's violent demise [was] used by the Provenzano Group either directly or subtly as a mechanism of intimidation." Id. at 312 .

274. Id. at 312-13.

275. Id. at 334 .

276. Id. at 311-12.

277. That those appointments may have been in technical compliance with the Landrum-Griffin Act's provisions concerning eligibility for union office, 29 U.S.C. $\$ 504$ (1982 \& Supp. V 1987), did not reduce their intimidating effect on the rank and file. See Local 560 III, 780 F.2d at 286.

278. Id. at 285-86.

279. Id. at 283,287 . The executive board defendants also gave known or reputed criminals access to Loeal 560 's offices. Id.

280. 29 U.S.C. $\$ 501($ a).

281. Local $560 \mathrm{I}, 581 \mathrm{~F}$. Supp. at 332. In Local $560 \mathrm{III}$, the court utilized the criminal standard for defining the elements of the aiding and abetting offense: "(1) that the substantive crime has been committed, and (2) that the defendant charged with aiding and abetting that crime knew of the commission of the substantive offense and acted with the intent to facilitate it." 780 F.2d at 284 (quoting United States v. Dixon, 658 F.2d 181, 189 n. 17 (3d Cir. 1981)). A later civil RICO decision 
In order to establish RICO hability from this pattern of conduct, the court still liad to determine whether the creation of that climate of intimidation was a predicate offense. Through a creative application of the Hobbs Act, ${ }^{282}$ the violation of which is a RICO predicate offense, ${ }^{283}$ the court concluded that it was. The Hobbs Act makes it a federal crime to affect interstate commerce by extorting property through the actual or threatened use of force, violence, or fear. ${ }^{284}$ The court essentially bootstrapped violations of title I of the Landrum-Griffin Act, ${ }^{285}$ which are not themselves predicate offenses, ${ }^{286}$ into Hobbs Act violations by defining the membership's interest in the "rights to union democracy" guaranteed by title $I$ as a Hobbs Act property interest. ${ }^{287}$ Although many courts liave apphied the Hobbs Act to extortion of other types of imtangible property, such as a company's right to make business decisions free from illegal outside pressure, ${ }^{288}$ the Local 560 decision was the first to desiguate Landrum-Griffin Act rights as property rights for Hobbs Act purposes.

In United States v. International Brotherhood of Teamsters, the court utilized the same approach wlien it denied a motion to dismiss the

by the same court applied a definition of aiding and abetting that entailed a less demanding intent requirement. Petro-Tech, Inc. v. Western Co., 824 F.2d 1349, $1356-57$ (3d Cir. 1987). See generally Comment, Aiding and Abetting Liability for Civil Violations of RICO, 61 Temple L. Rev. 1481 (1988).

282. 18 U.S.C. $\S 1951$ (1982).

283. See id. \& 1961(1).

284. Id. $\S 1951(b)(2)$. Although it has a much broader reach, combating labor racketecring was one of the Hobbs Act's major legislative purposes. United States v. Brecht, 540 F.2d 45, 51 (2d Cir. 1976), cert. denied, 429 U.S. 1123 (1977).

285. Title I is the "Bill of Rights of Members of Labor Organizations." See 29 U.S.C. $\S 411$ (1982).

286. The violent deprivation of a union member's Landrum-Griffin Act rights is in fact a crime, see Landrum-Griffin Act $\S 610,29$ U.S.C. $\S 530$ (1982), but not one designated by Congress as a RICO predicate act.

287. United States v. Local 560, Int'l Bhd. of Teamsters (Local 560 I), 581 F. Supp 279, 333 (D.N.J. 1984), aff'd, 780 F.2d 267 (3d. Cir. 1985), cert. denied, 476 U.S. 1140 (1986); see also United States v. Local 560, 550 F. Supp. 511 (D.N.J. 1982). The requisite effect on interstate commerce was present because when the membership's participation rights were extorted, "the actions of Local 560 were affected, which, in turn, resulted in affecting interstate commerce through businesses involved in interstate commerce." Local 560 III, 780 F.2d at 281 n.15.

288. See, e.g., Northeast Women's Center, Inc. v. McMonagle, 868 F.2d 1342, $1349-50$ (3d Cir.) (protesters at an abortion clinic violated the clinic's "property" right to conduct business under the Hobbs Act), cert. denied, 110 S. Ct. 261 (1989); United States v. Zemek, 634 F.2d 1159, 1174 (9th Cir. 1980) ("The right to make business decisions and to solicit business free from wrongful coercion is a protected property right."), cert. denied, 450 U.S. 916 (1981); United States v. Santoni, 585 F.2d 667, 673 (4th Cir. 1978) ("property extorted was the right ... to make a business decision free from outside pressure wrongfully imposed"), cert. denied, 440 U.S. 910 (1979); United States v. Tropiano, 418 F.2d 1069, 1075 (2d Cir. 1969) ("concept of property under the Hobbs Act ... is not limited to physical or tangible property or things"), cert. denied, 397 U.S. 1021 (1970). 
government's action to impose a trusteeship on the Teamsters International. ${ }^{289}$ By that time, however, the court had to overcome the argument, based on the Supreme Court's decision in McNally v. United States ${ }^{290}$ construing the mail fraud statute, ${ }^{291}$ that the democratic rights guaranteed to union menibers by Landrum-Griffin were, like the rights of citizens to honest government, so ethereal and intangible as to fall outside the property interests protected by the Hobbs Act.

The Teamsters court distinguished McNally in part by questioning whether McNally's interpretation of the mail fraud statute had any bearing on the Hobbs Act at all, since the Hobbs Act, unlike the mail fraud statute, expressly applied to labor racketeering. ${ }^{292}$ The court might also have noted that the definition of "extortion" in the Hobbs Act was modeled on that term's use in a New York extortion statute under which one court held that union membership rights are protected property interests "as real and as needful of equitable protection ... as nioney or chattels. ... If a niember has a 'property right' in his position on the [work] roster ... he has an equally enforcible property right in the election of men who will represent him in deahing with his economic security ....."293

But even assuming "property" has the same meaning in the Hobbs Act as in the mail fraud statute, McNally can be distinguished. First, the impact of McNally was sharply limited by Carpenter v. United States, which held that the nuail fraud statute can protect soine forms of intangible property. ${ }^{294}$ In fact, the interest in clean government at stake in $\mathrm{Mc}$ Nally might have qualified as a property interest if the case had been presented differently. ${ }^{295}$ Moreover, the McNally holding was partially motivated by the Court's reluctance to involve the "Federal governnient

289. 708 F. Supp. 1392, 1402 (S.D.N.Y. 1989); see also Rodonich v. House Wreckers Union, Local 95, 627 F. Supp. 176, 178-79 (S.D.N.Y. 1985) (rights under Labor Management Reporting and Disclosure Act classified as property rights within Hobbs Act).

290. 483 U.S. 350 (1987).

291. 18 U.S.C. $\$ 1341$ (1982).

292. Teamsters, 708 F. Supp. at 1397-99; see also United States v. Local 560 (I.B.T.) (Local 560 II), 694 F. Supp. 1158, 1188 (D.N.J. 1988).

293. Dusing v. Nuzzo, 177 Misc. 35, 37, 29 N.Y.S.2d 882, 884, modified on other grounds and aff'd, 263 A.D. 59, 31 N.Y.S. 2d 849 (1941); see also United States v. Local 560, Int'l Bhd. of Teamsters (Local 560 Im), 780 F.2d 267, 281 (3d Cir. 1985) (citing United States v. Enmons, 410 U.S. 396, 406 n.16 (1973)), cert. denied, 476 U.S. 1140 (1986).

294. 108 S. Ct. 316,320 (1987).

295. See McNally, 483 U.S. at 377 \& n.10 (Stevens, J., dissenting); see also Local 560 II, 694 F. Supp. 1158, 1188-89 (D.N.J. 1988); cf. United States v. Runnels, 833 F.2d 1183 (6th Cir. 1987) (union official who took kickback to steer members' workers compensation business to particular lawyer was guilty of mail fraud, since bribe was characterized as property belonging to the union). But see United States v. Holzer, 840 F.2d 1343, 1347-48 (7th Cir. 1988) (rejecting the Runnels analysis). 
in setting standards of disclosure and good government for local and state officials." 296 Not only is this federalism concern irrelevant to questions of good union government, but the Landrum-Griffin Act has already establislied the applicable standards. ${ }^{297}$

In any event, the superficial similarity between a citizen's right to lonest government and a worker's riglit to lionest umions can be misleading. Many in Congress understood the membership rights provided by Landrum-Griffin to be "economic rights . . . aris[ing] from economic problems and deal[ing] witl economic democracy. They are not . . . riglits . . . dealing with political democracy."298 Even if LandrumGriffin is seen as "bring[ing] to . . union members the reality of some of the freedoms from oppression that we enjoy as citizens by virtue of the Constitution," 299 the pohtical processes in umons are fundamentally different from those of public government because unions are essentially "one-party states." 300 With no institutionalized rival party to keep a critical eye on potentially corrupt incumbents, umon members will inevitably be more dependent on the courts to preserve their riglits to honest and democratic union governments-a fact implicity recognized by Congress when it enacted the Hobbs Act, Landrum-Griffin, and the civil RICO statute.

\section{Accommodating Federal Labor Policy}

A fundamental purpose of federal labor policy is to promote labor peace and economic stability by encouraging the practice of collective bargaining. ${ }^{301}$ A cornerstone of that policy is section 7 of the National Labor Relations Act (NLRA), which gives covered workers the right to orgamize or join unions and to participate in concerted activities for purposes of collective bargaining or other mutual aid or protection. ${ }^{302}$ In addition, the Act defines a variety of "unfair labor practices,"303 most of

296. McNally, 483 U.S. at 360 .

297. Teamsters, 708 F. Supp. at 1399.

298. 105 Cong. Rec. 6485 (1959), 1 LMRDA Legislative HistoRY, supra note 64, at 1111 (remarks of Sen. Carroll during debate over addition of title 1 to the bill) (emphasis added); see also Rodonich v. House Wreckers Union, Local 95, 627 F. Supp. 176, 179 n.2 (S.D.N.Y. 1985) ("[I]t would appear that LMRDA rights provide many union members with a source of livelihood.").

299. 105 CoNG. REC. 6472 (1959) (remarks of Senator McClellan).

300. See Summers, The Privatization of Personal Freedoms and Enrichment of Democracy: Some Lessons From Labor Law, 1986 U. ILI. L. REv. 689, 712. See generally Summers, Democracy in a One-Party State: Perspectives From Landrum-Griffin, 43 MD. L. REv. 93 (1984).

301. See National Labor Relations Act, as amended, § 1 (codified as amended at 29 U.S.C. $§ 151$ (1982)).

302. Id. $\S 7,29$ U.S.C. $\S 157$ (1982). Section 7 also gives workers the right to refrain from any of these activities. Id.

303. See id. $\S 8,29$ U.S.C. $\S 158$ (1982). 
which relate to employer or union violations of the rights created by section 7. Section 10 of the Act creates in the National Labor Relations Board (NLRB) the near exclusive source of remedies for those unfair labor practices. ${ }^{304}$

An important question in the context of union reform litigation, therefore, is the extent to which the traditional exclusivity of NLRB jurisdiction limits remedies otherwise available under civil RICO. When RICO violations in the labor settimg do not constitute unfair labor practices, of course, no difficulty exists. ${ }^{305}$ However, many RICO predicate acts $\mathrm{m}$ union reform cases, such as the use of violence to crush membership opposition to corrupt union officials, the receipt of payoffs to allocate work through union hiring halls, or the use of the mails or the wires to defraud dissident members of the fair handhing of their grievances, have been or could be held by the NLRB to be unfair labor practices. 306

That RICO and NLRB remedies might overlap is not enough to bar the RICO remedy, however; Congress clearly intended the availability of multiple remedies for some offenses. ${ }^{307}$ For example, when conduct violating section 7 of the NLRA also violates any of the three labor crimes that are expressly identified as RICO predicate acts, ${ }^{308}$ the legislative intent to allow the RICO remedies is clear. ${ }^{309}$ Similarly, where the substantive rights interfered with by RICO predicate acts have their roots in both section 7 and the Landrum-Griffin Act, Congress already has

304. See id. § 10, 29 U.S.C. $\$ 160$ (a) (1982 \& Supp. V 1987). In San Diego Building Trades Council v. Garmon, 359 U.S. 236 (1959), the Court held that "[w] then an activity is arguably subject to $\S 7$ or $\S 8$ of the Act, the States as well as the federal courts must defer to the exclusive competence of the National Labor Relations Board if the danger of state interference with national labor policy is to be averted." Id. at 245 (emphasis added). Two clear statutory exceptions to this general rule are section 302 of the amended Act, 29 U.S.C. $§ 186$ (1982 \& Supp. V 1987), which criminalizes employer payoffs to unions or union officials, and section 303 , id. $\S 187$, which creates a civil cause of action for victims of unlawful secondary boycotts. On labor law preemption generally, see Cox, Recent Developments in Federal Labor Law Preemption, 41 OH1O ST. L.J. 277 (1980); Cox, Labor Law Preemption Revisited, 85 HARV. L. REv. 1337 (1972).

305. See San Diego Building Trades, 359 U.S. at 245.

306. Cf. 1 THE DEveloping LABoR LAw, supra note 35, at 174-75 (violence or threats of violence may be an unfair labor practice); $i d$. at 253 (misconduct in administering hiring hall may be an unfair labor practice); 2 id. at 1328-37 (breach of duty of fair representation in grievance handling may be an unfair labor practice).

307. See supra note 304. As one court put it, "Congress gets to make the rules-and change them. Congress could, and did, create the NLRB as the exclusive forum for consideration of certain conduct, but ean and does create exceptions to that exclusivity." Butchers' Union, Local 498 v. SDC Inv., Inc., 631 F. Supp. 1001, 1006-07 (E.D. Cal. 1986).

308. See supra text accompanying note 253.

309. But see Local 335, Hotel, Motel, Restaurant \& Hi-Rise Employees Union v. Pier 66 Co., 599 F. Supp. 761, 763-65 (S.D. Fla. 1984) (action based on alleged violations of LMRA section 302(a)(3), 29 U.S.C. $\$ 186(\mathrm{a})(3)$ (1982), as RICO predicates preempted where conduct also constituted unfair labor practices, at least where the union's only damages were attorneys' fees and costs incurred by decertification efforts). 
demonstrated its intent to abandon NLRB exclusivity. ${ }^{310}$ Moreover, since the courts have long held that the NLRA does not preempt state criminal statutes of general applicability, ${ }^{311}$ and since many crimes defined by state law qualify as RICO predicates, ${ }^{312}$ it is also arguable that Congress did not intend the NLRA to limit RICO remedies for violations based on those predicate acts. ${ }^{313}$

On the other hand, the NLRA probably preempts RICO remedies in cases where employers or umions commit predicate offenses, such as mail fraud or wire fraud (which are not labor crimes per se) $\mathrm{m}$ order to violate employee rights that derive only from the NLRA. ${ }^{314}$ In order to accommodate federal labor policy, courts also should decline RICO jurisdiction over predicate acts committed in pursuit of legitmiate collective bargaining goals during the course of traditional labor disputes. ${ }^{315}$ In United States v. Enmons, the Supreme Court read such a limitation into the Hobbs Act. ${ }^{316}$ Congress's repeated refusal to overrule Enmons suggests that it did not intend RICO, a statute with legislative goals similar to those of the Hobbs Act, ${ }^{317}$ to apply to routine labor struggles. ${ }^{318}$

In addition to the NLRA, which focuses on collective bargaining, a second inajor source of federal labor pohicy is the Landrum-Griffin Act, which regulates internal union affairs. ${ }^{319}$ As discussed previously, that statute expressly preserves most alternative remedies available under state or other federal sources of law. ${ }^{320}$ However, the Act's post-election remedies for violations of its provisions governing fair elections of union officers do have preemptive force. ${ }^{321}$ Because a court-imposed RICO trusteeship may have the effect of nullifying the union's last election of

310. See supra text accompanying notes $272-300$.

311. R. GORMAN, BASIC TEXT ON LABOR LAW: UNIONIZATION AND COLLECTIVE BARGAiNING 768 (1976) (regulation of criminal activity is within exception to federal preemption of state law).

312. See supra text accompanying note 252 .

313. See Note, supra note 245 , at $235-36$.

314. See United States v. Boffa, 688 F.2d 919, 933-34 (3d Cir. 1982), cert. denied, 460 U.S. 1022 (1983); Butchers' Union, Local 498 v. SDC Inv., Inc., 631 F. Supp. 1001, 1010-11 (E.D. Cal. 1986). See generally Note, supra note 245 .

315. See infra note 652 and accompanying text.

316. 410 U.S. 396,401 (1973).

317. See supra text accompanying notes 282-88.

318. But see United States v. Thordarson, 646 F.2d 1323, 1329-30 (9th Cir. 1980) (use of explosives to damage an employer's truck not necessarily exempt from RICO charges even though the action was purportedly taken for a legitimate union purpose); see also Yellow Bus Lines v. Drivers Union, Local 639, 839 F.2d 782 (D.C. Cir. 1988) (allowing RICO action against union for strike activities without addressing the preemption issue).

319. See supra note 164 .

320. See supra text accompanying notes $166-71$.

321. Section 403 of the Act provides in pertinent part, "The remedy provided by this title for challenging an election already conducted shall be exclusive." 29 U.S.C. § 483 (1982). 
officers, defendants in the Local 560 and Teamsters cases argued that the Landruin-Griffin Act preempted the trusteeship reinedy. ${ }^{322}$ The courts properly rejected that argument, however, on the grounds that the purpose of the RICO actions in question was not to remedy specific election violations and "not to invalidate any particular election"; rather, the RICO actions had an altogether different goal: "to eliminate entirely the union's racketeering element." 323 In addition, the Teamsters court held that Landrum-Griffin's post-election remedies preempted only election challenges initiated by uinon members, not cases brought by federal prosecutors. ${ }^{324}$

Union defendants nevertheless might argue that Landrum-Griffin's election provisions preempt soine RICO structural injunctions in another way. A goal of the recently settled Teamsters case, for example, was to compel the IBT to change the inethod by which it elected its top national officers. ${ }^{325}$ But section 403 of the Landrum-Griffin Act states that "[n]o labor organization shall be required by law to conduct elections of officers ... in a different form or manner than is required by its own constitution or bylaws, except as provided by this subchapter."326 The legislative history, however, reveals that this language was directed only at election requirements that state law might have imposed. ${ }^{327}$ That Congress could have intended section 403 to preempt other federal requirements for the fair election of union officers is unlikely, since in 1959 no other requirements even existed.

Assuming, then, that structural injunctions and court-imposed trusteeships are available under civil RICO and are not preempted, important questions nevertheless remain. Can they be obtained in RICO

322. See United States v. Local 560, International Bhd. of Teamsters (Local 560 III), 780 F.2d 267, 295-96 (3d Cir. 1985), cert. denied, 476 U.S. 1140 (1986); United States v. International Bhd. of Teamsters, 708 F. Supp. 1358, 1395 (S.D.N.Y 1989).

323. Local 560 III, 780 F.2d at 280 n.13. "Put another way," the Teamsters court explained, "the alleged deprivation of union rights are symptoms; the complaint in this case alleges a widespread disease in the Union. The labor statutes are designed to treat these symptoms. RICO was enacted by Congress specifically to cure the disease." 708 F. Supp. at 1394.

324. 708 F. Supp. at 1394.

325. See infra text accompanying notes 573-609.

326. 29 U.S.C. $\$ 483$ (1982).

327. As the Senate Report explained:

There is great need for uniformity in the laws governing union elections. International and national unions operate in many States. It would be confusing, unduly burdensome, and often impossible for them to comply with a variety of election laws. . . . It is easier to enforce one uniform rule than a crazy quilt of State legislation and court decisions. Illconsidered State laws would interfere with the national labor policy ...

Accordingly, section 203 provides that no labor organization subject to the bill shall be required by State law to hold elections with greater frequency or in a different manner than is provided in the act.

S. REP. No. 187, 86th Cong., 1st Sess. 21-22 (1959), printed in LMRDA LEgisLative HisToRY, supra note 64, at 417-18 (emphasis added); see also Summers, supra note 168, at 135-36. 
cases brought by private parties, or are they available only to government prosecutors? On the larger question of the availability to private litigants of any equitable relief, the language of the statute is ambiguous ${ }^{328}$ and the courts are split. ${ }^{329}$ However, the better arguments support availability. ${ }^{330}$ If so, we must return to federal labor policy to determine whether that conclusion means that intrusive structural injunctions also must be available to private plaintiffs in union reform hitigation.

The answer depends on which private htigants seek such relief. Certainly the union itself, as a victinı of labor racketeering, has the necessary standing. However, if the union were sufficiently controlled by racketeers to be a legitimate candidate for a RICO trusteeship, those in control obviously would never authorize the lawsuit. ${ }^{331}$ Another possibility is that individual union menibers imght have standing to seek RICO structural injunctions, at least if they can "show that the directly injured party was under the continuing control or influence of the defendant or his

328. Section 1964(a) provides for the availability of injunctive relief in civil RICO litigation, and section 1964(b) authorizes the Attorney General to institute proceedings "under this section," without mentioning private plaintiffs, while section 1964(c) authorizes private plaintiffs to sue for treble damages and attorneys' fees, without mentioning equitable relief:

(a) The district courts of the United States shall have jurisdiction to prevent and restrain

violations of section 1962 of this chapter by issuing appropriate orders . . . .

(b) The Attorney General may institute proceedings under this section . . . .

(c) Any person injured in his business or property by reason of a violation of section 1962

of this chapter may sue therefore in any appropriate United States district court and shall

recover threefold the damages he sustains and the cost of the suit, including a reasonable attorney's fee.

18 U.S.C. $\S 1964$ (1982 \& Supp. V 1987).

329. Compare Bennett v. Berg, 710 F.2d 1361, 1365-66 (8th Cir. 1983) (McMillian, J., concurring) (injunctive relief available to private plaintiffs) and Cliambers Dev. Co. v. Browning-Ferris Indus., 590 F. Supp. 1528, 1540-41 (W.D. Pa. 1984) (same) with Religious Technology Center v. Wollersheim, 796 F.2d 1076, 1082-88 (9th Cir. 1986) (injunctive relief not available to private plaintiffs), cert. denied, 479 U.S. 1103 (1987) and Kaushal v. State Bank of India, 556 F. Supp. 576 (N.D. II1. 1983) (same).

330. See Blakey \& Cessar, supra note 254 , at 528 (failure to recognize equitable relief for civil RICO plaintiff "inconsistent with the text, legislative history and purpose of RICO"); Strafer, Massumi, \& Skolnick, Civil RICO in the Public Interest: "Everybody's Darling," 19 AM. CRIM. L. REV. $655,709-15$ (1982) ("actions brought by private parties to prevent and restrain racketeering activity thus further congressional intent"); Note, The Availability of Equitable Relief in Civil Causes of Action in RICO, 59 Notre DAME L. REV. 945, 945 (1984) (narrowing scope of RICO by precluding equitable relief for civil litigants contrary to "the express language of RICO and its liberal construction directive").

331. A national union trying to free one of its own locals from Mafia domination, however, might be a more likely civil RICO plaintiff: it could easily have a legitimate use for a RICO structural injunction to supplement the remedies available pursuant to its own constitution, and if mob infiltration had not reached the International, it might be willing to seek sucl an injunction. See supra text accompanying notes 87-92. 
henchmen." 332 To the extent the union itself is the real party in interest, ${ }^{333}$ the best answer may be a "hybrid RICO/section 501" action, in which umion members piggyback RICO claims onto a derivative action brought on behalf of their union pursuant to title $\mathrm{V}$ of the LandrumGriffin Act. ${ }^{334}$ If procedural prerequisites for a Landrum-Griffin section 501(b) action have been satisfied, ${ }^{335}$ and the fiduciary breaches underlying that action constitute the predicate offenses necessary to establish a RICO violation, ${ }^{336}$ permitting the title $V$ plaintiff to seek RICO remedies on her union's behalf is entirely consistent with the purposes of both statutes. ${ }^{337}$

On the other hand, in light of the grave danger that private parties could seek imtrusive forms of equitable relief to weaken or destroy unions, judges should be reluctant to grant them drastic relief. Employers victimized by strike-related violence, for example, have been permitted to pursue RICO damage claims against the striking unions, ${ }^{338}$ but such employers are so likely to be motivated by unlawful, anti-union animus that there should be an irrebuttable presumption against granting their requests for structural injunctions targetting their union adversaries. RICO claims growing out of bona fide labor disputes should be preempted outright. ${ }^{339}$ However, if they are not, awards of injunctive relief

332. Carter v. Berger, 777 F.2d 1173, 1178 (7th Cir. 1985).

333. Cf. Bass v. Campagnone, 838 F.2d 10, 12-13 (1st Cir. 1988) (individual union members lacked standing to assert RICO treble damage action where the injuries alleged were sustained by all union members collectively and not by plaintiffs individually).

334. 29 U.S.C. § 501(b) (1982); cf. Nordberg v. Lord, Day \& Lord, 107 F.R.D. 692, 700 (S.D.N.Y. 1985) (Civil RICO "may . . . be used by shareholders as an effective tool against racketeers. The only qualification is that the corporation must decide in the first instance whether to employ that tool.... If the corporation refuses to employ [RICO] after a proper demand has been made, and that decision is not made in good faith because the corporation itself is run by racketeers, Rule 23.1 permits the shareholders to assert the corporation's claims derivatively.") (dictum).

335. See M. MaLin, supra note 71 , at 315-20.

336. RICO designates criminal violations of title V, 29 U.S.C. $\S 501(\mathrm{c})$, as predicate acts. 18 U.S.C. § 1961(1)(c) (1982 \& Supp. V 1987).

337. Both RICO and Landrum-Griffin are remedial statutes intended to be liberally construed in order to effectuate their purposes. Moreover, both have as important legislative goals the elimination of union corruption and labor racketeering. The availability of RICO remedies, including treble damages, in appropriate title $\mathrm{V}$ cases thus would further both the RICO goal of deterring racketeer$\mathrm{mg}$ regardless of the setting and the title $\mathrm{V}$ goal of deterring corrupt unionism in particular. And by maximizing the transfer of wealth from labor racketeers to the unions they have victimized, the treble damages remedy would further advance the Landrum-Griffin Act's general goal of enabling unions to more effectively and honestly represent their members. Finally, without the hybrid RICO/section 501 action, the prospect of RICO civil relief ever being available when title V violations constitute RICO predicate acts would be seriously undermined, a result inconsistent with Congress' express designation of title V violations as RICO predicates. Cf. Bass, 838 F.2d at 12-13 (individual union members lack standing on their own behalf to maintain action under section 1964 (c) of RICO because injury is to union as a whole).

338. See supra note 318.

339. See supra text accompanying notes 315-18. 
in such cases would conflict directly with the spirit, if not the letter, of the Norris-LaGuardia Act, ${ }^{340}$ which reflects a "very clear Congressional intent to end injunctive interference in labor relations." 341

\section{Freedom of Association}

Discussion of the impact of structural injunctions on the associational rights of unions and their members has been conspicuously absent froin niost of the civil RICO union reform cases, and froin inost of the union reform litigation discussed in section IV of this Article as well. ${ }^{342}$ It is difficult to imagine a court today iniposing a trusteeship over a chapter of the NAACP without even addressing the first amendment imphications of such a reniedy. ${ }^{343}$ How different with unions: not one of the four judges who authored opimions upholding RICO trusteeships and decreeships in the Local 560 and Philadelphia Roofers cases offered even a trace of first amendment analysis. ${ }^{344}$ This well illustrates what one

340. 29 U.S.C. $\$ \S 101-15$ (1982 \& Supp. V 1987).

341. Texas \& N.O.R.R. v. Brotherhood of R.R. Trainmen, 307 F.2d 151, 155 (5th Cir. 1962), cert. denied, 371 U.S. 952 (1963). Cf. Burlington N. Ry. v.Brotherhood of Maintenance of Way Einplyees, 481 U.S. 429 (1987) (Norris-LaGuardia Act bars injunctions against secondary boycotts in railroad industry).

342. But see Hotel Employees Local 54 v. Read, 832 F.2d 263 (3d Cir. 1987) (upholding New Jersey Casino Control Act's disqualification of union officers with criminal backgrounds); International Longshoremen's Ass'n v. Waterfront Comm'n, 642 F.2d 666 (2d Cir. 1981) (upholding New York Waterfont Commission Act disqualification of union officers with criminal backgrounds); In re Hotel \& Restaurant Employees Local 54, 203 N.J. Super. 297, 496 A.2d 1111 (App. Div.), certif. denied, 102 N.J. 352 (1985), cert. denied, 475 U.S. 1085 (1986) (upholding Casino Control Act disqualification of union officers with criminal backgrounds or association).

In United States v. International Bhd. of Teamsters, 708 F. Supp. 1388, 1393 (S.D.N.Y. 1989), the court avoided a mling on the first amendment issues, but stated:

[W] hen ... association is part of a plan to commit a crime it is no longer protected. Otherwise, it is apparent that any RICO enterprise or conspiracy could never be prosecuted because they all involve "association." "Freedom of association" is not, however, a talisman that will ward off all government attempts to proscribe or regulate activity. It is only lawful association that is protected, not association for a criminal or unlawful purpose.

343. Cf. NAACP v. Claiborne Hardware Co., 458 U.S. 886, 907, 916 (1982) (NAACP boycott of white Mississippi merchants was constitutionally protected expression absent violence, so antitrust damages unavailable); NAACP v. Alabama ex rel. Flowers, 377 U.S. 288 (1964) (Alabama may not use either procedural technicalities or corporation laws to stifle freedom of association); NAACP v. Button, 371 U.S. 415, 428 (1963) (NAACP has standing to seek redress of claimed infringements of the associational rights of the organization and its members); NAACP v. Alabama ex rel. Patterson, 357 U.S. 449, 466 (1958) (NAACP need not comply with Alabama law requiring "foreign corporations" to file membership lists).

344. See United States v. Local 560 (I.B.T.) (Local 560 II), 694 F. Supp. 1158 (D.N.J. 1988) (Debevoise, J.) (enjoining certain individuals with criminal associations from running for urion office); United States v. Local 560 (Local 560 III), 780 F.2d 267 (3d Cir. 1985) (Garth, J.) (affirming liability findings and the imposition of RICO trusteeship); United States v. Local 560 (Local 560 I), 581 F. Supp. 279 (D.N.J. 1984) (Ackerman, J.) (making findings of liability and imposing RICO trusteeship); United States v. Local 30, United Slate, Tile, and Composition Roofers, 686 F. Supp. 1139 (E.D. Pa. 1988) (Bechtle, J.) (making liability findings and imposing RICO “decreeship"). 
commentator has dubbed the first amendment's "black hole" in the labor relations setting. ${ }^{345}$

It is, nevertheless, well settled im other contexts that the first annendment's freedom of association extends to umion activity. ${ }^{346}$ That freedom, though, is not absolute; merely because union reform litigation implicates associational rights does not necessarily mean that structural injunctions violate those rights. Associational rights entitled to even the highest levels of protection ${ }^{347}$ can be overcome by "coinpelling state interests, unrelated to the suppression of ideas, that cannot be achieved through means significantly less restrictive of associational freedonis." 348

Intrusive remedies in labor racketeering cases may affect two sets of associational interests. First are the rights of the innocent victims of the racketeering activity-the infiltrated unions and their inembers-to associate for expressive purposes. Certainly, reinoving a union's elected leadership from office and appointing an outside trustee to run its day-to-day affairs severely compromise the union's and the membership's freedom to associate. But im cases like Local 560, in which racketeers had violently extorted the members' rights to participate deniocratically in the governance of their union, ${ }^{349}$ a RICO trusteeship, rather than violating those

345. Pope, Labor and the Constitution: From Abolition to Deindustrialization, 65 TExAs L. REV. 1071, 1074 (1987).

346. See, e.g., Lyng v. UAW, 108 S. Ct. 1184, 1189 (1988) (first amendment associational rights encompass "the combination of individual workers together"); Roberts v. United States Jaycees, 468 U.S. 609, 637-38 (1984) (O'Connor, J., concurring) (citing cases limiting state's power to require association with union engaged in ideological activities); Smith v. Arkansas State Highway Employees, Local 1315, 441 U.S. 463, 464-65 (1979) (first amendment "protects the right of associations to engage in advocacy on behalf of their members"); Abood v. Detroit Bd. of Educ., 431 U.S. 209, 233 (1977) (first amendment protects the freedom of an individual to associate in a union context); UMW v. Illinois State Bar Ass'n, 389 U.S. 217, 225 (1967) (first amendment rights violated by Illinois state law against union's use of in-house counsel); Railroad Trainmen v. Virginia, 377 U.S. 1, 5-6 (1964) (first amendment association rights protect the union's policy of recommending lawyers to members).

347. Association for purely commercial purposes may be entitled to less protection than association for purposes of political advocacy. See Roberts v. United States Jaycees, 468 U.S. 609, 634 (1984) (O'Connor, J., concurring). Unions, of course, are organized to further both political and economic (as well as social) goals, but their "commercial purposes of engaging in collective bargaining," id. at 638 , cannot easily be separated from their political activities, $c f$. Eastex, Inc. v. NLRB, 437 U.S. 556 (1978) (workplace distribution of union newsletter protected under NLRA where newsletter addressed both issues of immediate workplace concern and state and federal legislation that would have only indirect effect on workplace). As a result, unions targeted for intrusive structural injunctions in union reform cases should be entitled to the highest levels of first amendment protection.

348. Roberts v. United States Jaycees, 468 U.S. 609, 623 (1984).

349. See supra text accompanying notes 263-81. 
rights, actually restores associational rights the mob has already destroyed. ${ }^{350}$

Banning individuals with criminal backgrounds or associations from holding umion office also might restrict the expressive interests of umions and their members, ${ }^{351}$ since interference with an organization's choice of spokesperson can impinge the effectiveness of the organization's communication. No court, however, has yet held that "the umion's right to free association extends so far as to include a right to elect particular officers." 352 Also, in section 504 of the Landruin-Griffin Act, ${ }^{353}$ "Congress has unmistakably indicated that the right of employees to select the officers of their bargaining representatives is not absolute and necessarily admits of some exception." 354 According to one court, such a restriction "is akin to a reasonable regulation of the manner of expression and only incidentally affects the union's expressive activity." 355 Nevertheless, because the removal of a particular spokesperson could in soine instances have devastating effects on a union's ability to communicate effectively, ${ }^{356}$ such bans are appropriate in labor racketeering cases only in the absence of less restrictive ineans of achieving the coinpelling governmental purpose of insulating unions from racketeers. ${ }^{357}$

Intrusive remedies in umion reforin cases also may infringe on a second set of associational rights: the rights of the individuals who are removed or banned from union office because of their own criminal backgrounds or those of their unsavory associates. These associational

350. See United States v. Local 560 Int'l Bhd. of Teamsters (Local 560 III), 780 F.2d 267, 296 n.39 (3d Cir. 1986) (appointment of a temporary trustee "protect[s] rather than forfeit[s] the members' rights"); Benson, supra note 115 (same); Comment, Union Receiverships Under RICO: A Union Democracy Perspective, 137 U. PA. L. REv. 929, 960 (1989) (same).

351. In Local 560, for example, government prosecutors sought and obtained a RICO injunction barring certain individuals from running for union office. See infra text accompanying notes 414-16.

352. Hotel \& Restaurant Employees Local 54 v. Read, 832 F.2d 263, 267 (3d Cir. 1987); cf. NLRB v. International Union of Operating Eng'rs, Local 501, 806 F.2d 1405 (9th Cir. 1986) (NLRB order reinstating improperly expelled members does not violate union's freedom of association); Vicksburg Firefighters Ass'n, Local 686 v. Vicksburg, 761 F.2d 1036 (5th Cir. 1985) (city's ban on fire department captains and lieutenants joining union held not to violate union's freedom of association).

353. 29 U.S.C. § 504(a) (1982).

354. Brown v. Hotel \& Restaurant Employees Int'l Union Local 54, 468 U.S. 491, 505 (1984).

355. Read, 832 F.2d at 267.

356. Examples might be the removal of Cesar Chavez from his position in the United Farm Workers Union or, in another setting, the removal of Jesse Jackson from the Rainbow Coalition.

357. See In re Hotel \& Restaurant Employees Int'l Local 54, 203 N.J. Super. 297, 326, 496 A.2d 1111, 1127 (App. Div.) (balancing the state's interest in policing organize crime with the union's rights of association), certif. denied, 102 N.J. 352, 508 A.2d 223 (1985), cert. denied, 475 U.S. 1085 (1980); cf. Trade Waste Management Ass'n v. Hughey, 780 F.2d 221, 236 (3d Cir. 1985) (upholding a state ban against persons with "bad reputations" from participating in the waste disposal business). See also B. Lee \& J. Chelius, Organized Crime and Unions: An Exanination of the Freedom of Association Conflict 23-24 (unpublished manuscript). 
rights fail to rise to constitutional significance, since "it is only lawful association that is protected, not association for a criminal or unlawful purpose." 358 Thus, if a court finds that an individual's criminal associations facilitate the extortion of the urron membership's democratic rights, those associations warrant little deference, regardless of whether they are asserted as a mode of expression or as an aspect of intimate association ${ }^{359}$ based on family friendships. ${ }^{360}$

Accommodation of first amendment values in union reform litigation, in addition to being constitutionally required, also prods judges to devise remedies in a maimer that maximizes their effectiveness while minimizing their intrusiveness. The Supreme Court has already held, in a union reform settimg, that "combatimg local crime infesting a particular industry" is "a legitimate and conupelling state interest." 361 By requiring that interest to be protected by the least drastic remedy likely to be effective, the first amendinent forces the court to evaluate the likely effectiveness of not only the remedies proposed by the plaintiff, but of less restrictive alternatives as well-a process that educates the judge and nuay result in remedies that are nore carefully crafted, and more effective, than would otherwise be the case.

This discussion sets the stage for an analysis of the effectiveness of the structural injunctions (and consent decrees) that have been utilized in the nost important recent examples of umion reform litigation.

358. United States v. International Bhd. of Teamsters, 708 F. Supp. 1388, 1393 (S.D.N.Y. 1989). See also NAACP v. Claiborne Hardware Co., 458 U.S. 886, 916 (1982) ("The First Amendment does not protect violence.... When such conduct occurs in the context of constitutionally protected activity, however, 'precision of regulation' is demanded.") (quoting NAACP v. Button, 371 U.S. 415, 438 (1963)).

359. The Supreme Court has applied freedom of association analysis, primarily on privacy rather than freedom of expression grounds, to protect from undue state intrusion "choices to enter into and maintain certain intimate human relationships," such as those relating to "the creation and sustenance of a family." Roberts v. United States Jaycees, 468 U.S. 609, 618, 619 (1984).

360. Cf. Trade Waste Management Ass'n v. Hughey, 780 F.2d 221, 237-39 (3d Cir. 1985) (keeping waste disposal industry free of people with questionable integrity advances New Jersey's interest in keeping organized crime out of this sensitive industry). In Hughey, the court stated:

The state has identified the waste disposal business as one that is particularly sensitive to infiltration by organized crime. Its choice to exclude persons having bad reputations from participating in that industry is a necessary element of preventing the criminal infiltration that the licensing scheme is designed to prevent. It is the risk of infiltration that is the state's coinpelling interest, and exclusion on the basis of bad reputation appears to be the only means of avoiding that risk. Id. at 239.

361. Brown v. Hotel \& Restaurant Employees Int'1 Union Local 54, 468 U.S. 491, 509 (1984) (quoting De Veau v. Braisted, 363 U.S. 144, 155 (1960)) (upholding against a pre-emption challenge state legislation disqualifying from union office individuals with criminal background or associations) 


\section{The Remedies Applied at THE Local Level}

The preceding sections of this Article have delnonstrated that intrusive structural injunctions, including court-imposed trusteeships, are available to the courts in union reform hitigation. But a retnedy's availability does not necessarily inean that it should be applied in a given case, or that it will be effective if apphied. As Professor Gewirtz has micely put it, "The idea of a perfect remedy is a frequent illusion, defied by a resisting, inultidimensional world." 362 Accordingly, this section and the next will supplement the somewhat abstract discussion thus far with a concrete examination of the application of structural injunctions to unions in the real world. ${ }^{363}$

\section{A. Teamsters Local 560}

The judicially supervised reform of corrupt labor umions entered a new era in 1986 with the government's use of civil RICO to obtain a court-innosed trusteeship over Tony Provenzano's Teamsters Local $560 .{ }^{364}$ In 1982, when federal prosecutors filed their coinplaint, the 8,000-meniber Teainsters local in Union City, New Jersey, presented an inviting target for a test case. As the court eventually found, the local had been "infiltrated and ultimately captured" through an "orgy of criminal activity" by a "group of gangsters" headed by Tony Provenzano, a "inade ineinber" of the Genovese orgainzed crime family. ${ }^{365}$ For decades, Provenzano and his associates repeatedly engaged in virtually every known form of labor racketeering, froin einbezzling union funds, loansharking, pilferage, and selling out the interests of the membership in exchange for payoffs and kickbacks, to beating inany and inurdering at least one, and inaybe two, rank-and-file challengers to the Provenzano Group's domination. 366

The corruption in Local 560 had proven inpervious to a variety of less drastic renedies over the years. In 1959, for example, the Teainsters

362. Gewirtz, Remedies and Resistance, 92 YALE L.J. 585, $591-92$ (1983).

363. As Professor Gewirtz correctly stated:

To be of the law, as opposed to philosophy and economic theory ... one must take reality as the primary realm of activity. Law moves beyond articulation to implementation, and legal scholarship therefore must address the complexities of acting within an imperfect, resisting, often vulgar real world. In law, reality is not a footnote to theory or an appendix to the ideal. The claims of reality are a central intellectual imperative as much as a practical one.

Id. at 680 .

364. The district court first ordered the trusteeship in 1984, but stayed the remedy pending appeal. United States v. Local 560, Int'1 Bhd. of Teamsters (Loeal 560 I), 581 F. Supp. 279, 337

(D.N.J. 1984), aff'd, 780 F.2d 267 (3d Cir. 1985), cert. denied, 476 U.S. 1140 (1986).

365. Id. at $282,304$.

366. See supra text accompanying notes 26-47. 
Board of Monitors had sought to compel Jimmy Hoffa to bring internal union charges against Provenzano and to have Provenzano expelled from the union, but Hoffa refused.367 Similarly, in 1978, following Provenzano's incarceration for murder, members of PROD, an organization of Teamster reformers, formally petitioned the international to impose an intra-union trusteeship on the local. This time Frank Fitzsimmons, Hoffa's hand-picked successor as IBT President, refused. ${ }^{368}$

Nor did a long string of criminal convictions (including four of Tony Provenzano himself), ${ }^{369}$ even in combination with the statutory ban against labor felons holding union office for five (now thirteen) years after the completions of their prison sentences, ${ }^{370}$ loosen the Provenzano Group's grip on Local 560. Provenzano "ran [that] union with an iron hand whether im or out of prison or office,"371 and the district court explained how: "Sain and Nunzio [Provenzano] played musical chairs in minding the store waiting for Tony to satisfy the technical requirements of the law." 372

367. See infra text accompanying note 539.

368. Fitzsimmons deried that the Local 560 executive board's selection of Tony Provenzano's daughter, Josephine, as Tony's replacement might suggest that Local 560 was still under Tony's influencc. Far from disciplining the Provenzano Group, the IBT's top leadership repeatedly welcomed one Provenzano or another into its own inner circle of International Vice Presidents. See Goldberg, supra note 89, at 9.

369. In 1963, Provenzano was convicted of taking "labor peace" payoffs from an employer; in 1978 he was convicted of taking kickbacks relating to a benefit fund loan; also in 1978 Provenzano was convicted for the 1961 murder of union rival Anthony Castellitto; and in 1979 he was again convicted of taking "labor peace" payoffs. United States v. Local 560, Int'1 Bhd. of Teamsters (Local 560 D), 581 F. Supp. 279, 289-90 (D.N.J. 1984), aff'd, 780 F.2d 267 (3d Cir. 1985), cert. denied, 476 U.S. 1140 (1986).

370. The Comprehensive Crime Control Act of 1984 amended section 504 of the LandrumGriffin Act to authorize debarment periods of up to thirteen years, increase the number of crimes for which debarment is available, and prohibit convicted union officials from remaining in office while their appcals are pending. Pub. L. No. 98-473, $\S 803,98$ Stat. 2133-34 (codified as amended at 29 U.S.C. § 504(a) (1982 \& Supp. V 1987)). See generally Panter, The Changes Accomplished by the Labor Racketeering Amendments of the Comprehensive Crime Control Act of 1984, 36 LAB. L.J. 744 (1985).

371. Local 560 I, 581 F. Supp. at 293. As the court of appeals elaborated, "During periods in which Anthony Provenzano was either incarcerated or subject to statutory disability, he sought and received his increased salary and pension payments, received the Romano Loan kickbacks, and reccived his Seatrain labor peace payoffs." United States v. Local 560, Int'1 Bhd. of Teamsters, (Local 560 III), 780 F.2d 267, 293 (3d Cir. 1986).

372. Lacal $560 \mathrm{I}, 581 \mathrm{~F}$. Supp. at 293. The court continued:

Although several key associates of the Provenzano Group are incarcerated ... the resilience which it demonstrated during the late 1960's-while three key associates (Anthony Provenzano, Nunzio Provenzano and Salvatore Briguglio) were incarcerated-... lead[s] inescapably to the conclusion that various nominees and successors will continue the Provenzano Group's "criminal business" as usual. Yet another generation of extortionists can be expected to be recruited to fill-out the slightly depleted ranks of the Provenzano 
Following a fifty-eight day trial, Judge Harold A. Ackerman made his liability findings and ordered Local 560's executive board removed froin office, to be replaced by a trustee appointed by the court. He stayed those remedies, however, pending appeals that lasted more than two years. Finally, on June 23, 1986, Local 560's RICO trusteeship became effective. $^{373}$ Judge Ackerman named as Trustee Joel R. Jacobson, who seemed an excellent choice. As a twenty-five year veteran of the labor movement, ${ }^{374}$ Jacobson had the credentials to run the union effectively and to help insulate the trusteeship from the mevitable charge that it was a "union busting" ploy of a Reagan administration unfriendly to organized labor. Moreover, as a former member of New Jersey's Casino Control Commission, 375 Jacobson appeared knowledgeable about the nature of organized crime and the methods appropriate for holding its remaining influence within Local 560 in check. Finally, as a longtime friend of Judge Ackerman, ${ }^{376}$ Jacobson could be expected to work well with a judge deeply cominitted to making the trusteeship work.

The order establishing the trusteeship gave Jacobson "all authority and power to act as he may ... see fit to administer the affairs . . . of Local 560, and to create and foster conditions under whicli reasonably free, supervised elections can be lield by Local 560."377 Those powers mcluded, but were not limited to, all of the powers previously held by the officers and executive board members of Local 560 pursuant to the local's bylaws and the IBT's constitution. The order gave Jacobson complete control over the local's organizing, collective bargaining, and grievance handling activities. It also gave him the power to hire and fire the local's paid staff and to make any appropriate expenditures froin the local's treasury. ${ }^{378}$

Group-unless and until the conditions within Local 560 which spawned and nurtured the events of the last twenty-two years are dramatically altered.

Id. at 319.

373. See Order Appointing Trustee, United States v. Local 560, Int'l Bhd. of Teamsters, C.A. No. 82-689 (D.N.J. June 23, 1986) [hereinafter Order Appointing Trustee].

374. Jacobson had held numerous offices in the International Ladies Garment Workers Union, the United Automobile Workers, and the New Jersey CIO and AFL-CIO. Penn, Mob's Legacy: Teamstcr Local Greets Court Trustee Angrily After He Takes Reins, Wall St. J., Feb. 10, 1987, at 1, col. 6.

375. Jacobson also served on New Jersey's public utility commission and headed the state's energy department. Id.

376. Early in his career, Ackerman had worked with Jacobson in the New Jersey labor novement, and for a time they were related by marriage. See Galen, Union Suits, Nat'z L.J., Aug. 31, 1987, at 1, 29.

377. Order Appointing Trustee, supra note 373, at 2.

378. Id. at 2-3. The costs of the trusteeship were thus borne by the union's treasury, but given the union's past spending patterns, the treasury actually came out ahead. Under Jacobson, the union's paid staff grew from eleven to fourteen, and cost the local $\$ 1500$ less in weekly payroll 
One of Jacobson's first decisions was also one of the most important: whether to retain the seven paid business agents and 400 unpaid shop stewards who had served under the old regime. 379 Jacobson had the power to remove them, ${ }^{380}$ and Judge Ackerman urged hin to do so. ${ }^{381}$ Ackerman beheved that a clean sweep of all who had worked with the Provenzanos was necessary to weaken the remnants of the Provenzano machine. It also would liberate the membership from the fear that open opposition to that machine could expose them to the risk of losing their jobs because of intentionally poor grievance handling by hostile business agents and stewards. ${ }^{382}$

While Jacobson generally agreed with the need to replace the business agents, it took him over six months to do so. ${ }^{383}$ Some critics charged that several of the replacements that he appointed, though screened by the FBI, were in fact Provenzano loyalists. ${ }^{384}$ Jacobson decided to retain most of the shop stewards for two reasons. First, he felt he would be unable to effectively carry out his collective bargaining and contract administration duties without relying upon their knowledge of the more than 300 employers and numerous contracts under which the members of Local 560 worked. Second, since workplace elections had chosen many of the stewards, Jacobson believed it would be inconsistent with the trusteeship's purpose of restoring democracy to remove them without individual showimgs of misconduct. ${ }^{385}$

expenses. See Prial, U.S. Court Runs a Jersey Union in Test, N.Y. Times, Mar. 28, 1987, at 29, col. 2.

379. In non-factory locals like Local 560, business agents are the backbone of the union's paid bureaucracy. They process grievances, often participate in negotiations, and generally spend much of their time visiting job sites to handle difficulties that arise. Shop stewards are ordinary workers elected or appointed to serve as the union's spokesperson at the job site and, often, as their coworkers' representative within the union. Stewards usually help process grievances through the first steps of the grievance procedure. J. WALliHAN, supra note 69, at 8, 82, 104-06.

380. The court's order gave the trustee that power, subject to any limitations created by the local's bylaws or the IBT constitution, and the local's bylaws in turn gave the local president thc power to appoint and remove stewards and, with the consent of the executive board, appoint and remove business agents. See Const. and Bylaws of Local $560 \$ 6.02$ [hereinafter Bylaws].

381. See Jacobson, "Guilty Until Proven Innocent": How the Teamsters Trusteeship Turned Sour, N.J. Reporter, Mar. 1988, at 15.

382. Remedies for such breaches of the union's duty of fair representation arc theoretically available but "extremely difficult to enforce." United States.v. Local 560 (I.B.T.) (Local 560 II), 694 F. Supp. 1158, 1190 (D.N.J. 1988). See generally Goldberg, The Duty of Fair Representation: What the Courts Do In Fact, 34 Buffalo L. Rev. 89 (1985).

383. See Letter from Joel R. Jacobson to Judge Harold A. Ackerman (Oct. 23, 1986), reprinted in 560 Free Press, Dec. 1987, at 6 [hereinafter cited as Jacobson Letter]. For a description of the newspaper, 560 Free Press, see infra text accompanying note 403.

384. See Galen, supra note 376 , at 30 .

385. See Jacobson, supra note 381 , at 18. 
It is hard to quarrel with Jacobson's first reason for retaining the stewards, although he might have looked for other ways to nuaintain his effectiveness on bread-and-butter issues while reducing his dependence upon the old stewards. Jacobson's second reason, however, despite some superficial appeal, was ill-founded. Given the level of fear and intimidation that existed during the old regime, and the power that Provenzano and his surrogates had to remove from office any stewards they disliked for any reason, ${ }^{386} \mathrm{few}$ union members independent of the Provenzano machine would have been hikely to run for steward positions. If they did run and win, they would not have kept those positions for very long. And in fact many stewards repeatedly and forcefully denionstrated their loyalty to Provenzano's remaining associates in the local during the course of the trusteeship. ${ }^{387}$

Jacobson's decision to replace busmess agents gradually and shop stewards not at all typified his approach to the trusteeship. He viewed himself first and foremost as "a union man, not a cop." His role, as he saw it, was to demonstrate to the membership how much more effective an honest, dedicated, and militant trade unionist like himself could be in protecting their jobs and improving their wages and working conditions. Jacobson believed that once the menibers understood what they had been missing during the corrupt Provenzano years, candidates deterinined to create honest unionism would einerge as the trusteeslip drew to a close and would defeat any potential slates comprised of Provenzano loyalists. 388

That approach was surprisingly naive for a man of Jacobson's background and experience. True, the trusteeship under Jacobson was very effective on bread-and-butter issues. New contracts provided annual wage increases substantially greater than the national average, fringe benefits iniproved, grievances were handled forcefully, and the local's meinbership grew by twenty-six percent. 389 Jacobson, however, grossly underestiniated the strength of the Provenzano loyalists who were still active in the union and who were led by former Local 560 president Michael Sciarra ${ }^{390}$ and former vice president Joseph

386. Bylaws, supra note $380, \S 6.02$.

387. See infra text accompanying notes $392-419$.

388. See Jacobson, supra note 381 , at 18.

389. Id. at 19.

390. Sciarra was named president of Local 560 by the local's executive board on October 29, 1984, following the conviction of his predecessor, Salvatore Provenzano, for defrauding a local benefit fund and for receiving kickbacks with respect to the local's dental plan. See United States v. Local 560 (I.B.T.) (Local 560 II), 694 F. Supp. 1158, 1160 (D.N.J. 1988). Sciarra, one of the original defendants in the Local 560 case, had served as a Local 560 business agent since 1972 and as a trustee of the Local from 1981 until he was named president in 1984. See United States v. Local 560, Int'l Bhd. of Teamsters (Local 560 I), 581 F. Supp. 279, 288 (D.N.J. 1984). Sciarra's loyalty to the 
Sheridan. ${ }^{391}$ As a result, Jacobson made little effort to investigate Sciarra and Sheridan for wrongdoing or to otherwise discredit them within the local. On the contrary, by retaining the incuinbent shop stewards he played into their hands; he provided Sciarra with a powerful political base from which he could seek to regain control of the local.

Sciarra and Sheridan formed a campaign organization known as "Teamsters for Liberty" (TFL). In numerous incidents stewards used their positions to coerce and intimidate members into signing petitions opposing the trusteeship and buying baseball caps inscribed "Free 560," with proceeds presumably going into a Sciarra slate cainpaign fund. ${ }^{392}$ TFL organized several public deinonstrations ained at pressuring Judge Ackerman into ordermg an early end to the trusteeship, and it recruited numerous New Jersey politicans, religious leaders, and civic organizations to jom that campaign. ${ }^{393}$ TFL was also a moving force behind a collateral attack on the trusteeship filed in April, 1988. ${ }^{394}$

TFL adherents also brought their intimidation tactics into stewards' and meanbership meetings called by Jacobson or his successor, and Jacobson was nearly heckled off the stage by Sciarra and his supporters on several occasions. ${ }^{395}$ After viewing the videotape of one particularly raucus membership meeting, Judge Ackerman concluded that Jacobson's approach to the trusteeship was not working. ${ }^{396}$ According to one knowledgeable observer, "the problem was that [Jacobson] didn't create the feeling there was a new regime," 397 a problem symbolized by the prominent display of Tony Provenzano's portrait in the Local 560 office

Provenzanos was evidenced by Sciarra's own testimony at the Local 560 trial, see id. at 302.03, and was subsequently confirmed by government wiretaps, which indicated that the Genovese crime family, of which Provenzano was a member, "controlled" Sciarra. Local $560 I I, 694$ F. Supp. at 1172. See infra text accompanying note 414 .

391. Sheridan had been vice president of the local from July, 1981 until the start of the trustecship. Previously, he had served as a local business agent from 1976 to 1978 and as trustee from 1978 to 1981. See Local 560 II, 694 F. Supp. at 1162.

392. See Penn, supra note 374, at 26, col. 6; New Trustee Installed in Jersey Local 560, ConvoY Dispatch, June-July 1987, at 10 [hereinafter $\mathrm{New}$ Trustee].

393. See Local 560 II, 694 F. Supp. at 1185.

394. McGarrigle v. Stier, C.A. No. 88-1738 (D.N.J. filed Apr. 15, 1988); Local 560 II, 694 F. Supp. at 1185 .

395. See Local 560 II, 694 F. Supp. at 1185; Galen, supra note 376, at 29; Storm Erupts Over Fote During Six Hour Marathon Meet, 560 Free Press, Feb.-Mar. 1988, at 4; Shop Stewards at Raucus Meeting Elect Steering Committee of Ten, 560 Free Press, Oct. 1987, at 2.

396. As Judge Ackerman later explained:

Seeing Sciarra coming down the aisle like Rocky with his arms up and being led by two business agents still on the payroll, and seeing no one get up to denounce Sciarra's criticism of the trusteeship.... [ [w] hen I saw that, I realized that $I$ had to move in high gear to purge this union of these nefarious elements.

Quoted in Galen, supra note 376, at 29.

397. Id. at 30 (quoting Herman Benson, Executive Director of the Association for Union Democracy). 
during Jacobson's entire tenure as trustee. ${ }^{398}$ Even Jacobson admitted that dissenters within the local still feared reprisals. ${ }^{399}$ If that fear prevented many members from risking open opposition to Sciarra during the trusteeship, it would virtually assure Sciarra's election at the conclusion of the trusteeship. A return to conditions in the local much as they were before was almost certain. ${ }^{400}$

In response to this possible scenario, Judge Ackerman removed as trustee the "union man" Jacobson on May 12, 1987, and replaced him with a "cop," Edwin H. Stier, a former Assistant United States Attorney and Director of the New Jersey State Division of Criminal Justice. ${ }^{401}$ Despite his lack of labor movement experience, Stier, like Jacobson was effective on bread-and-butter umion issues, in part because he had the help of a newly-appointed associate trustee who was an experienced union official. 402 He also improved administration of the local's pension and benefit funds, imitiated publication of a monthly newspaper, "The 560 Free Press," and took steps to encourage umion membership involvement with union affairs. ${ }^{403}$ Stier was also much more aggressive than Jacobson in digging for evidence that might discredit Sciarra with the membership or lead to the imposition of civil or criminal sanctions. ${ }^{404}$

In December, 1987, Stier reported to Judge Ackernnan that after eighteen months of trusteeship, the local was "still suffering from the effects of more than twenty five years of racketeer domination."405 Despite "widely held resentment toward the Provenzano group," according to Stier, the membership was not yet "willing to become actively involved ... if it means challenging someone who has been in power in the Umion"406_an obvious reference to former president Michael Sciarra. Therefore, Stier recommended that the court extend the trusteeship for

398. See id. at 29.

399. See Prial, supra note 378, at 29, col. 2.

400. See Local S60 II, 694 F. Supp. at 1191.

401. See United States v. Local 560, 126 L.R.R.M. (BNA) 2190, 2191 (D.N.J. 1987). Jacobson later asserted that his discharge resulted from his refusal to support Judge Ackerman's view that "when it comes to members of Local 560 they're guilty until proven innocent." United States v. Sciarra, 851 F.2d 621, 624 (3d Cir. 1988) (quoting Jacobson affidavit). Sciarra and Sheridan subsequently used Jacobson's affidavit to that effect in support of an unsuccessful notion to force Judge Ackerman to recuse himself from further participation in the case. See id.

402. Frank Jackiewicz, the associate trustee, was a longtime official of New Jersey Teamsters Local 843 and a former secretary and chief negotiator of the Brewery Worker's Joint Local Executive Board of New Jersey. Local 560, 126 L.R.R.M. (BNA) at 2191.

403. See Letter from Edwin H. Stier to Judge Harold A. Ackerman (Dec. 4, 1987), reprinted in 560 Free Press, Dec. 1987, at 6 [hereinafter Stier Letter].

404. See Kiely, Cleaning Up Teamsters Local 560, The Record (Hackensack, N.J.), May 15, 1988 , at A1.

405. Stier Letter, supra note 403.

406. $I d$. 
another year, with elections to be held at the end of 1988, following Justice Department investigations which "may have an impact on the eligibility of certain individuals to run for office." 407 The court complied with Stier's recommendations ${ }^{408}$ and in February, 1988, ordered Sciarra and Sherdian to provide deposition testimony to federal prosecutors concerning Sciarra's 1984 to 1986 performance as Local 560's president and his alleged links to the Genovese crime family. ${ }^{409}$

While that investigation was proceeding, the union election campaign got under way. ${ }^{410}$ In addition to the TFL slate headed by Sciarra and Sheridan, two opposition slates emerged, including one headed by Ray Carney, who had run unsuccessfully on anti-Provenzano slates in the last two contested elections held by the local, in 1962 and 1965.411 The Sciarra slate was heavily favored, however, ${ }^{412}$ in part because of its political base in the remnants of the Provenzano nrachine and the intimidation tactics sometimes resorted to by its supporters. ${ }^{413}$

In Septeinber, 1988, just weeks before a nembership meeting at which candidates for office would be formally noninated, the court granted a government inotion, endorsed by Stier, for an injunction barring Sciarra and Sheridan from running in the December election, despite the fact that neither had ever been convicted of a crime. ${ }^{414}$ In support of the injunction, the court cited wiretap evidence indicating that the Genovese crime family had "direct control" over Sciarra, "the Family's chosen imstruınent" for continuing its domination of Local 560 after the court hifted the trusteeship. ${ }^{415}$ The court also relied on evidence that Sciarra, while president of the local, entered into a "sweetheart" arrangeinent with an einployer at the behest of the mob; permitted a Local 560 benefit plan administrator to remain in office after he had been convicted of obstruction of justice in a case involving fraud upon the plans; and continued to contract with corrupt providers of a inembership legal services plan "under circumstances so extraordinary as to almost defy belief."416

407. Id.

408. Letter Opinion and Order, United States v. Local 560, C.A. No. $86-0689$ (Dec. 17, 1987), reprinted in 560 Free Press, Dec. 1987, at 5.

409. See United States v. Sciarra, 851 F.2d 621, 632-33 (3d Cir. 1988).

410. See Noble, Vote Set to End U.S. Control Over Jersey Teamsters Local, N.Y. Times, Feb. 15, 1988, at B3, col. 1.

411. See Kiely, supra note 404.

412. See id.; Noble, supra note 410.

413. See supra text accompanying notes $392-406$.

414. United States v. Local 560 (I.B.T.) (Local 560 II), 694 F. Supp. 1158, 1169, 1172 (D.N.J. 1988).

415. Id. at $1169,1172$.

416. Id. at $1179,1181$. 
Despite Sciarra and Sheridan's disqualification, the election results did not please the government. Michael Sciarra's brother Danny and Joseph Sheridan's nephew Mark, running on the TFL slate as open surrogates for their disqualified relatives, defeated the two reform slates by an almost two-to-one margin. ${ }^{417}$ Following the election, trustee Ed Stier returned the day-to-day operations of the local to its newly elected officers, although he continued to oversee the local's pension and benefit funds and retained the power to monitor the union's affairs and investigate wrongdoing. ${ }^{418}$ As of this writing, Michael Sciarra, serving in his brother's administration as a business agent, is "clearly in charge" of Local 560.419

Any explanation of the Sciarra victory must begin with Local 560's long history of coercion and fear. As one newspaper reported, ["w] hen it became apparent that Sciarra had won, none of the United Ticket backers wanted to give a name. A trucker said: 'Fear is returning to the uinion with Sciarra back ni control. You not only worry about your job but your health, too, if you go against him." "420 However, it is also true, as Joel Jacobson reported to Judge Ackerman in late 1986, that "inany members do not comprehend the connection between a 'Provenzano' and a 'Provenzano-selected' heutenant. . . . Sciarra had been a Business Agent for over a dozen years, and enjoyed a reputation as an aggressive battler for the inembers." 421 Moreover, not all members who saw the link between Sciarra and the Provenzanos were necessarily troubled by that connection. The Provenzano Group had had decades to cement loyalties with large seginents of the membership through patronage and commumity and etlinic ties, and since the umon's members worked at

417. See Noble, Union Vote Could Change Tradition, N.Y. Times, Dec. 4, 1988, at 52, col. 4; Sullivan, Teamsters Elect Slate Linked to Mob, N.Y. Times, Dec. 8, 1988, at B1, col. 5.

418. See Sullivan, Local 560 Says It Helped to Set Stage for Accord, N.Y. Times, Mar. 14, 1989, at D28, col. 5 .

419. Id. Although the government had opposed the newly elected executive board's decision to hire Sciarra, Judge Debevoise, who had barred him from running for office, refused to bar his appointment as a BA. See U.S. Senate Permanent Subcomm. on Investigations, Comm. on Gov't Affairs, Hearings on the Federal Government's Use of Trusteeships Under the RICO Statute, 101st Cong., 1st Sess. 11-12 (Apr. 6, 1989) (statement of Edwin H. Stier) [hereinafter Trusteeship Hearings].

420. Kiely, Teamster Election Goes to Sciarra, The Record (Hackensack, N.J.), Dec. 7, 1988, at A1. On several occasions during the campaign, reform candidates received death threats, and there was evidence of ballot tampering by stewards. See Moran, Risking Death for Local 560, The Record, Oct. 16, 1988, at A1; Democracy in Local 560, The Record, Dec. 8, 1988, at B8.

421. Jacobson Letter, supra note 383. Unlike the Provenzanos, who were virtually never seen at early morning worksite or "barn" meetings, Sciarra "was diligent in visiting the various terminals every morning where the members saw him, liked him, and appreciated him." Id. As the court noted in the very ruling disqualifying Michael Sciarra and Joseph Sheridan from running, "for many union members [they] may have performed substantial services . . . and acted at times as dedicated trade unionists." Local 560 II, 694 F. Supp. at 1191. 
hundreds of workplaces, even the rampant levels of corruption found in Local 560 may have had a direct effect on only a minority of its meinbers; many others undoubtedly saw Provenzano as a Robin Hood figure. ${ }^{422}$

Another factor explaining Sciarra's apparent popularity was the absence of credible alternatives. Even the most democratic unions are typically "one-party states," where dominant factions can retain office for decades by centralizing power, controlling the umion's bureaucracy and its channels of commumication, and characterizing opposition to incumbent umion leaders as disloyalty to the union itself. ${ }^{423}$ In Local 560, these natural advantages of incumbency were for years reinforced by the brutal suppression of any organized dissent. After two years of trusteeship, organized opposition to the Provenzano-Sciarra faction had energed, but it was seriously disadvantaged by the fact that it was largely inexperienced and unknown.

Finally, the vote in Local 560 was not only an election of officers, but also, to some extent, a referendum on the RICO trusteeship itself.424 For some members, the heavy handedness of the remedy shifted the focus away from the corruption of the Provenzano regime to the danger of umion busting by a conservative Republican administration. The eleventh hour candidate disqualifications reinforced that view, making martyrs of Sciarra and Sheridan and "freedom fighters" of TFL.

To declare the Local 560 trusteeship a failure, however, would be a mistake. Fears that prosecutors were using the suit to destroy the union were unfounded, and conditions in Local 560 were undoubtedly better at the end of the trusteeship than they were when the trusteship began. Indeed, the same conditions that made Local 560 a good candidate for a RICO trusteeship at the start-deeply rooted corruption, the absence of a democratic tradition, and a membership too intimidated to do much about it-meant that no remedy was likely to be an instant or total success. The court and its trustee will continue monitoring conditions in the local, and federal prosecutors will continue battling organized crime's influence in Local 560 on other fronts as well.425 A final evaluation of the trusteeship's effectiveness must await future elections and the performance of any opposition slates that may emerge.

422. See Penn, supra note 374 , at 1.

423. See Summers, supra note 300 , at $95-98$.

424. See Teamsters for Liberty, Letter to the Editor, 560 Free Press, Apr. 1988; Lazare, Feds Out, Mob Back in After Teamsters Vote, In These Times, Dec. 21, 1988, at 8; Raskin, Teamster Local, Once Run by Mob, Tries the Ballot Box, N.Y. Times, Nov. 20, 1988, at E6, col 4.

425. See, e.g., United States v. Gigante, Civ. No. $88-4396$ (D.N.J. filed Oct. 13, 1988) (seeking to void a sweetheart contract affecting Local 560 members). 


\section{B. Cement \& Concrete Workers Local $6 \mathrm{~A}$}

In June, 1986, just as the Teamsters Local 560 trusteeship was getting under way, federal prosecutors in New York filed the second civil RICO case to seek a judicially imposed trusteeship over a corrupt labor union. In United States v. Local $6 A$, Cement \& Concrete Workers International Unions, ${ }^{426}$ the coinplamt, based in large part on facts established during a successful prosecution of leading figures in the Colombo organized crime family, ${ }^{427}$ alleged that the 1400 -meinber Local 6A, and the 4000 member District Council to which it belonged, had become "captive labor organizations," used by the Colombo organization to extort payoffs from concrete construction contractors, steal union funds, and create a chimate of intimidation and fear among the members. ${ }^{428}$

Given the strength of their case in hight of the prior criminal convictions, federal prosecutors immediately sought a preliminary injunction to oust the local and joint council officers and replace them with trustees to conduct the umion's business pendente lite. ${ }^{429}$ Nine months later, before a ruling on that motion, the union defendant ${ }^{430}$ agreed to a consent judgeinent that created a remedy designated a trusteeship, but which, unlike the Local 560 trusteeship, was far from a total takeover of the local by the court appointed trustee. ${ }^{431}$

Pursuant to the agreement, sixteen of the twenty-five local and joint council officers resigned their positions. ${ }^{432}$ The reinaining officers retained their positions, subject to the powers of the trustee, Eugene R. Anderson, a New York lawyer and former federal prosecutor whoin the

426. 663 F. Supp. 192 (S.D.N.Y. 1986).

427. United States v. Persico, 646 F. Supp. 752 (S.D.N.Y. 1986), aff'd in part, rev'd in part, 832 F.2d 705 (2d Cir. 1987), cert. denied, 108 S. Ct. 1995 (1988). The Cement Workers litigation was also based on United States v. Salerno, 85 CR 139 (S.D.N.Y. 1986), in which one of the convicted defendants was Ralph Scopo, then president of the union's district council.

428. See Barnes, Suit Seeks Federal Trusteeship Over Cement Workers Local, UNion DEMOcRACY REv., Nov. 1986, at 8. Local 6A, an affiliate of the Laborers International Union, was only one of many unions in the New York City construction industry that allegedly had been taken over by La Cosa Nostra. See N.Y. TASK ForCE, supra note 34, at 73-79.

429. Cement Workers, 663 F. Supp. at 193.

430. The "union defendants," as opposed to the "Colombo Family defendants," were the two labor organizations and 25 of their officers and members. See id. at 194.

431. Judgment (On Consent) Against Union Defendants, United States v. Local 6A, Cement \& Concrete Workers, 86 Civ. 4819 (S.D.N.Y. Mar. 18, 1987) [hereinafter Consent Judgment]. The union defendants were running out of funds to pay their attorneys when they agreed to the consent judgment. Remarks of Eugene Anderson, Local 6A Trustee, Union Trusteeship Conference of New York Organized Crime Task Force (Jan. 29, 1988) [hereinafter Anderson Remarks].

432. Seven officers were permanently enjoined from any further dealings with the union, six were permanently enjoined from holding union office, and three were barred from union office only until the end of the trusteeship. Id. at 3-7. 
court chose from a hist of six candidates agreed to by the parties. ${ }^{433}$ Anderson had general power "to oversee the operations" of the local and the joint council. He also had the specific authority to remove union officers, busmess agents, and shop stewards for acts of racketeering or malfeasance, or for knowingly associating with La Cosa Nostra meinbers, and to veto any contracts or expenditures constituting or furthering acts of racketeering or malfeasance. ${ }^{434}$ The consent judgment also instructed the trustee to conduct new elections for local and joint council officers in late 1987, and agam in 1990, after which time the trusteeship would end, unless extended by the court. ${ }^{435}$ The trustee could hire any accountants, investigators, or other staff necessary to assist him in his duties, and all trusteeship expenses were to be paid by the defendant unions. ${ }^{436}$

Anderson began his tenure as trustee on April 6, 1987, planning to play "a cop's role."437 Due to limited resources, however-the local and district council treasuries had been depleted by legal fees associated with the underlying civil RICO action"38-Anderson found it "problematic ... even to hire an accountant to review the books and records of Local 6A and the District Council" at the start of the trusteeship, much less to put his investigatory powers to significant use. ${ }^{439}$ Nevertheless, he subsequently concluded that, at least on the surface, no evidence existed of corruption among the union officials remaining from the old guard, perhaps because "they know they are under a microscope, so they are clean now, waiting out the end of the trusteeship." 440

Whether they will stay clean after the trusteeship is lifted, of course, remains to be seen. What seems more certain is that, as in Teamsters Local 560, the officers in place at the end of the trusteeship are likely to have been close associates of those ousted at the start. Perhaps due to "an element of fear and intimidation" 441 resulting from the fact that the mcumbent officers "are viewed by the rank-and-file as part of the old

433. Id. at 7; Galen, N.Y.-Based Union Agrees to Less-Radical Approach, NAT.'L L.J., Aug. 31, 1987, at 1, 30, col. 1 .

434. Consent Judgment, supra note 431, at 7-12.

435. Id. at $16-17,20$.

436. Id. at 18-19.

437. See Galen, supra note 433.

438. See Trusteeship Hearings, supra note 419, at 5 (statement of Eugene R. Anderson).

439. Id. On the other hand, Justice Department investigation of Local $6 \mathrm{~A}$ continued even after the trusteeship was established. See id. at 15 (statement of Floyd I. Clarke, FBI Executivc Assistant Director).

440. Anderson Remarks, supra note 431; see also Trusteeship Hearings, supra note 419, at 6 (statement of Eugene R. Anderson).

441. Telephone interview with attorney Robert Gaynor, assistant to the trustee (Mar. 24, 1989). 
regime," not a single office im Local 6A or the Joint Council was contested when elections were held in late 1987.442 The trustee recognizes the importance of greater participation by the rank-and-file im the union's affairs, but he has been unable to generate significant participation, in part, he beheves, because he is "merely a . . . watchdog" without "the hands on, day-to-day responsibility of running the union." He explained that "only if the trustee becomes in effect the union leadership can a relationship of trust develop with the rank-and-file and can the rank and file eventually feel that they can safely assume control over their own destinies." 443

\section{Teamsters Local 814}

Like the Cement \& Concrete Workers litigation, the Justice Department's third attenipt to impose a RICO trusteeship over a corrupt union was part of a larger effort to put a New York organized crime family out of business. ${ }^{444}$ In United States v. Bonanno Organized Crime Family, 445 the government alleged that a Mafia crime family had a "stranglehold" on Teamsters Local 814, a 3000 member Queens, New York local representing workers in the inoving and storage industry and at sports and exhibition centers in the New York area. One of the defendants named in the suit was Jaines Bracco, president of Local 814 until October, 1986, who, together with the local's then secretary-treasurer, was convicted of labor racketeering and extortion in the moving and storage mdustry. 446 Other defendants im the government's suit included his son Ignatius Bracco, who replaced him as the local's president, Local 814 itself and its executive board, and the Local 814 pension and benefit funds and their trustees. ${ }^{447}$

Again, the government moved almost inninediately for a preliminary injunction placing the local under the control of a court-appointed trustee pendent lite. ${ }^{448}$ This time, however, the imjunction would have

442. Trusteeship Hearings, supra note 419, at 3 (statement of Eugene R. Anderson). However, a number of black union members, previously unrepresented among the officers, were included on the new Local 6A and District Council executive boards, perhaps because of discussions Anderson held with the union's officers. Id. at $8 \mathrm{n} .9$.

443. Id. at 3-4.

444. See Buder, Civil Suit Is Filed by U.S. to Curb a Crime Family, N.Y. Times, Aug. 27, 1987, at $\mathrm{Al}$, col. 1 .

445. Civ. No. 87-2974 (E.D.N.Y. filed Aug. 25, 1987).

446. See Buder, supra note 444, at B2, col. 6; Jennik, Federal Judge Imposes Trusteeship Over Teamsters Local 814, Union Democracy ReV., Jan. 1988, at 4.

447. See Buder, supra note 444, at B2, col. 6 .

448. See Order to Show Cause for Preliminary Injunction and Order for Expedited Discovery at 6, United States v. Bonanno Organized Crime Family, Civ. No. 87-2974 (E.D.N.Y. Aug. 26, 1987). 
specifically instructed the trustee to take steps to proinote union democracy and greater rank-and-file involvement in the local. For example, the injunction would have estabhished an advisory executive board comprised of five Local 814 ineinbers to act as business agents, handle grievances, and carry out the union's collective bargaining responsibilities. Members would elect new shop stewards by secret ballot, and within six inonths, a stewards' council would serve as an advisory body on collective bargaining. In addition, the injunction would have created a grievance coinmittee coinprised of selected shop stewards to hear coinplaints about grievance handhing and to inake recoinniendations concerning pending grievances. Finally, the injunction would have initiated a niembership education program, focusing on collective bargaining issues, democracy, and safety. 449

Within weeks, the union defendants entered into a consent judgment which provided for the resignations of the local's executive board members and pension and benefit fund trustees, and barred the union's president and secretary-treasurer froin participating in the union's affairs for five years. 450 The agreeinent also provided for the appointment of a trustee, but placed niost of the authority for running the local's day-today affairs in an Interim Executive Board (IEB) comprised of two of the locals' former officers who had been screened by the U.S. Attorney's Office and the FBI. ${ }^{451}$

Under the consent decree, the trustee, Arthur Eisenberg, a former regional director of the NLRB's New Jersey region, ${ }^{452}$ could 1) participate in the deliberations of the IEB and cast a deciding vote in the case of tie; 2) have access to all books, accounts, and records of the local and the pension and benefit funds; 3 ) obtain accountings of union and fund assets and petition the court to enjoin any inproper union expenditures in ex. cess of $\$ 5000$; 4) conduct a study of the local's job referral system and, "with the advice and consent of the Interim Executive Board, which shall not be unreasonably withheld," implement any appropriate

449. Id. at 8-9.

450. Consent Judgment with Local 814, Local 814 Executive Board, Local 814 Funds, Ignatius Bracco and Vito Gentile at 10, United States v. Bonanno Organized Crime Family, Civ. No. 87-2974 (E.D.N.Y. Oct. 8, 1987) [hereinafter Consent Order].

451. Id. at 11; Trusteeship Hearings, supra note 419, at 20 (Apr. 12, 1989) (statement of Peter R. Ginsberg, Assistant U.S. Attorney). One former officer, former recording secretary Robert Corbett, was made interim president, and the second, former trustee James O'Connor, was made interim secretary-treasurer. See Jennik, supra note 446, at 4. Two members were also selected, after Justice Department and FBI screening, to comprise an interim Board of Trustees. See Trusteeship Hearings, supra note 419 , at 20.

452. Consent Order, supra notc 450, at 4; Buder, Decree Approved to Help Rid Union of Mob, N.Y. Times, Oct. 10, 1987, at 35, col. 4. 
changes; 5) recommend to the IEB the removal of any local or fund official or agent found to be corrupt or in dereliction of her duties, and to petition the court for such removal if it is not approved by the IEB; and 6) petition the court for any additional powers necessary to respond to any corruption he discovered. ${ }^{453}$ Some but not all of the provisions for greater membership involvement im the union's governance that had been sought in the preliminary injunction were included in the consent judgment. A membership council was created to serve as an advisory body to the IEB, and a meinbership education prograin was ordered. ${ }^{454}$ Elections of new officers, to be supervised by the trustee and the DOL, were to be held in October, 1988, after which time the trusteeship would terminate. ${ }^{455}$

In addition to his watchdog function, Eisenberg as trustee served as an advisor to the relatively inexperienced IEB, "participating fully in the day-to-day activities and meetimgs."456 This role evolved into that of mediator and conciliator after the two IEB ineinbers had a falling out. 457 On bread-and-butter matters such as contract negotiation and enforcement, Eisenberg reports that Local 814 has performed reasonably well during the trusteeship, 458 and the operation of the local's pension and welfare funds has greatly improved. 459 The union's job referral system also has been cleaned up, with a switch from a part-time to a full-time dispatcher and the elimination of such abuses as dispatches made for a fee froin certain "social clubs" rather than the umion hall. 460

The trusteeship also has sought to promote democracy and greater membership participation within the local. The local revived a long dormant union newsletter; a rank-and-file ineunbership council, which meets monthly, serves as an advisory body to the IEB; and ineinbership meetings are more frequent, better attended and include more discussion and floor debate than in the past. ${ }^{461}$ The trustee and DOL supervised election of new officers, held four inonths late in February of 1989, suggests that a corner may have been turned in restoring democracy to Local 814: two slates of candidates ran, headed by the two meinbers of the IEB, and

453. Consent Order, supra note 450 , at 4-9.

454. Id. at 7 .

455. Id. at 9 .

456. See Trusteeship Hearings, supra note 419, at 2 (statement of Arthur Eisenberg).

457. Telephone interview with Arthur Eisenberg (Mar. 31, 1989).

458. Trusteeship Hearing, supra note 419, at 5-6 (statement of Arthur Eisenberg).

459. For example; fund audits and new collection procedures brought in nearly $\$ 500,000$ in delinquent employer contributions, and new fund investment managers were retained at a savings of $\$ 267,000$. One of the local's funds, which had been in the red two years earlier, contained almost $\$ 600,000$ by early 1989 . See id. at $2-4$.

460. See id. at 4; telephone interview with Arthur Eisenberg (Mar. 31, 1989).

461. See Trusteeship Hearing, supra note 419, at 4-6 (statement of Arthur Eisenberg). 
each won about half of the officer positions. Voter turnout was triple that of past elections in the local. ${ }^{462}$

\section{Roofers Local 30}

The fourth and most recent case in which federal prosecutors obtained civil RICO structural rehef over a corrupt union local is United States v. Local 30, United Slate, Tile and Composition Roofers Association. ${ }^{463}$ It too was largely based on prior criminal prosecutions: in November, 1987 thirteen officers and employees of the local, including its chief executive, business manager Stephen Traitz, were convicted. ${ }^{464}$ Following a preliminary injunction hearing in which over seventy witnesses testified, the court found that Local 30, which represents approximately 2000 commerical and residential roofing construction workers in the Philadelphia area, "has been doininated over inore than twenty years by a creed of violence, unlawfuhress and defiance of authority" that was imposed "by force, fear and intimidation upon the roofing industry and much of the Union meinbership." 465

More specifically, the court found that the union and its leadership had used violence against roofing contractors to extract payoffs and coerce umonization. ${ }^{466}$ In addition, numerous union officers and employees had taken kickbacks and payoffs related to the operation of the union's pension and benefit funds and had enbezzled monies front the funds. ${ }^{467}$ The union used some embezzlement proceeds to bribe public officials ${ }^{468}$ and unlawfully spent over $\$ 1$ million on defense costs associated with the prior criminal prosecutions of union officials. ${ }^{469}$ The court held that, simce at least 1981, Local 30 had been under the influence of

462. See id. at 5; id. at 14 (statement of Peter R. Ginsburg). As of this writing, however, challenges to the conduct of the election were still pending with the DOL, and the trusteeship's duration had been extended. See Trusteeship Hearing, supra note 419, at 5 (statement of Arthur Eisenberg).

463. 686 F. Supp. 1139 (E.D. Pa. 1988), aff'd, 882 F.2d 512 (3d Cir. 1989). In a fifth case, involving alleged Mafia corruption of New York City's Fulton Fish Market, the court, pursuant to a consent deeree, appointed an administrator to monitor the inarket's cleanup. Consent Judgment, United States v. Local 359, United Seafood Workers, Sinoked Fish \& Cannery Union, 87 Civ. 7351 (S.D.N.Y. Apr. 15, 1988). The union defendant in that case, however, Local 359 of the United Seafood Workers, refused to join in the consent decree. Following an August 1988 trial, the court dismissed the civil RICO case against the union and its officers on the grounds that the government had failed to prove its clain that the union had been taken over by the Genovese crime family. United States v. Local 359, United Seafood Workers, Sinoked Fish \& Cannery Union, 87 Civ. 7352 (S.D.N.Y. slip. op. Jan. 24, 1989).

464. United States v. Traitz, Cr. 86-451 (E.D. Pa. 1987), aff'd, 871 F.2d 368 (3d Cir. 1989).

465. Roofers Local 30, 686 F. Supp. at 1162.

466. Id. at $1150-51$.

467. Id. at 1155 .

468. Id.

469. Id. at 1158. 
Philadelphia La Cosa Nostra boss Nicodenı Scarfo, who used union power to collect his gambling and drug debts. ${ }^{470}$ Scarfo also helped to nistall Traitz as Local 30 business manager following the nuurder of Traitz' predecessor, Jolin McCullough. ${ }^{471}$

In that environment, not surprisingly, union democracy did not flourish. Violence and threats of violence directed against Local 30 menibers were commonplace, and dissidents often found theniselves unable to obtain work through the union's hiring hall. For twenty years before the December, 1987 election to replace the convicted officers, no race for the position of business manager had ever been contested. ${ }^{472}$ In that election, held just days before the start of the preliminary injunction hearing, opposition candidates and their supporters suffered discharges from union eniployment, reniovals from shop steward positions, threats of violence, loss of hiring hall referrals, and disruption of their efforts to distribute campaign literature at a union ineetnig. Long time associates of the thirteen convicted officials won the election and reappointed all of the business agents who had served the old regime. ${ }^{473}$ Many union members, as well as contractors, "fear[ed] attending meetings" and "fear[ed] ... that if they go to the Union Hall to resolve a dispute or problem ... they will be outnumbered, intimidated, threatened with physical violence and/or physically beaten"- $a$ fear which the court found to be "legitimate and well-founded."

Given these findings, the court agreed with the Justice Department that drastic remedies might be appropriate and even asserted that it would be "fully justified ... to dissolve the Union and make an equitable distribution of its assets." 475 The court rejected that option, "at least for now." It also rejected the government's request for a Local 560-type trusteeship, on the grounds that

court-imposed trusteeships have not worked as well as have been expected.... The shortcoming of a trusteeship ... is clearly the distasteful and unworkable act of forcing an authority figure on the existing Union leadership and membership, who they are required to be loyal to, and indeed, expected to like. History has shown that this has rarely worked in the political world and there is no reason to expect it to work in the labor Union circumstance now before the court, especially where the authority figure is replacing individuals and policies that have theretofore in great measure been supported, enforced, or at least

470. See id. at 1157.

471. See id.

472. See id. at 1162.

473. See id. at 1159-61.

474. Id. at 1162 .

475. Id. at 1167 . 
tolerated by the very membership who would be ruled over by the unwanted trustee. 476

At the other extreme, the court considered equally unworkable the defendants' suggestion that the umion be permitted to operate as before, subject only to a court-imposed momitorship. ${ }^{477}$

As an alternative, the court decided to "leav[e] the Union institution and its present leadership in place, but then [to] remov[e] from Union control those areas of activity which the Union has misused in the past."478 It endeavored to do so by creating a "decreeship" pursuant to which all face-to-face negotiations between employers and the union must be conducted in the presence of a court-appointed court liaison officer who, as the decree's "principal enforcement officer," would have to certify any resulting collective bargaining agreements as having been negotiated $\mathrm{m}$ an atmosphere free of intimidation or violence before the agreements could be given effect. The decree also required the union and the relevant contractors associations to negotiate new grievance procedures for their collective bargaining agreements. It prohibited union officials from spending or transferring any union or fund assets, except for ordinary business expenditures, without the court's approval. In addition, the decree barred the thirteen individual defendants from any union office or position of authority in the imdustry, and provided for a financial audit of the local and its affiliated pension and benefit funds. Finally, it gave the court haison officer access to all umon and fund records, as well as the authority to hire any necessary staff. All costs of the decreeship were to be borne by the local and its funds. ${ }^{479}$

The decreeship went into effect on May 23, 1988, and Judge Louis C. Bechtle named as court liaison officer Philadelphia attorney Robert E. Welsl, Jr., a former Assistant U.S. Attorney and former law clerk to Judge Bechtle.480 According to Welsl, the decreeship has resulted in "substantial progress . . . in the Umion's relations witl the outside world,

476. Id. In light of the court's own findings regarding the level of intimidation operating within Local 30, the degree of actual rank-and-file support for the local's leadership would seem debatable. On the other hand, it is true that in Roofers Local 30, unlike Teamsters Locals 560 and 814 and Cement Workers Local 6A, some of the illegal conduct directed at employers was intended to benefit the union's membership, not just its corrupt officers.

477. Id.

478. Id. at 1168. The court left open the possibility that the newly elected business manager and an executive board member who lad invoked their fifth amendment privileges at the trial would be removed from office pursuant to the AFL-CIO Codes of Ethieal Practices, see id. at 1161-62, 1170, 1172 , but the AFL-CIO subsequently informed the court liaison officer that it considered the relevant Code provisions defunct. Telephone interview with Robert E. Welsh, Jr. (July 27, 1989) [hereinafter Welsh interview].

479. Roofers Local 30, 686 F. Supp. at 1171-74.

480. Welsh interview, supra note 478. 
inost particularly in collective bargaining." 481 During a recently concluded round of contract negotiations, several work stoppages occurred, but union violence and intimidation were greatly reduced, and Welsh believes that the agreement reached was superior, froin the imion's perspective, to the contract negotiated prior to the decreeship. ${ }^{482}$ The decreeship also has brought about improvements in the union's financial practices; for example, the union has adopted many of the measures recoininended by the accountants who conducted the court ordered audit, as a means to proinote greater accountability and efficiency. ${ }^{483}$

Welsh concedes, lowever, that little progress has been made in the area of internal union democracy, ${ }^{484}$ despite the court's imstruction that its decree be applied "to protect, as inuch as possible, the right of Union inembers to fully participate in the Union affairs, including the right to vote, to assemble, to speak freely, [and] to be treated fairly . . ."485 Union officers continue to denounce dissenters at union ineetings as traitors and stooges of the federal prosecutors and continue to target thein for econonic retahation through abusive hiring hall practices.486 In June, 1989 elections held pursuant to court order, the incumbent officers, linked to the corrupt old guard, were reelected by a two-to-one margin over an opposition slate. Although the balloting itself was without incident, ${ }^{487}$ the challengers conducted their cainpaign in an atmospliere of intense intimidation. At a inenibership ineeting two months before the vote, for example, the incumbents whipped their supporters into such a frenzy of hostility toward the opposition candidates that reformers had to flee the meeting for their personal safety. 488 No end for the Roofers Local 30 decreeship has yet been planned, and Welsh suggests that it could last for five or more years. 489

481. Trusteeship Hearing, supra note 419 , at 3 (statement of Robert E. Welsh, Jr.).

482. See id.; Welsh interview, supra note 478. Less encouraging was the inability of union and employer negotiators to agree on the adoption of the contractual grievance procedure mandated by the court. Welsh, therefore, drafted one himself, and the court imposed it on the industry. Although the arbitration clause has yet to be invoked, Welsh believes that its existence has faciliated the resolution of numerous grievances. See Roofers Local 30,686 F. Supp. at 1172; Welsh interview, supra note 478.

483. See Trusteeship Hearing, supra note 419, at 2-3 (statement of Robert E. Walsh, Jr.).

484. Id. at 3.

485. Roofers Local 30, 686 F. Supp. at 1173.

486. Welsh has indicated that reform of the union's hiring hall is on his and the court's agenda, but as of this writing no such reforms have been announced or implemented. Welsh interview, supra note 478.

487. The election procedures were established by Welsh, with assistance from the DOL, and the balloting itself was overseen by the American Arbitration Association. Id.

488. Id.

489. Id. 


\section{Remedial Alternatives at the National LeVel}

The structural relief recently extracted by federal prosecutors from the International Brotherhood of Teamsters as part of the price of settling their civil RICO trusteeship case against the IBT ${ }^{490}$ does not represent the first time a federal court has involved itself in the day-to-day operations of the Teamsters union. Thirty years ago, union reformers obtained a similar remedy in Cunningham v. English, ${ }^{491}$ a rank-and-file lawsuit which originally sought to prevent Jimmy Hoffa's election as General President at an IBT convention stacked with illegally selected delegates pledged to Hoffa's candidacy. This section examines these two ambitious and controversial efforts to reform the powerful Teamsters union.

\section{A. The Teamsters Board of Monitors 492}

When Dave Beck announced in the Spring of 1957 that he would not seek reelection as General President of the International Brotherhood of Teamsters, $493 \mathrm{Jimmy}$ Hoffa seemed a sure bet to be elected to succeed him at the union's September convention, but as the convention approached, Hoffa fell under attack from all sides. He had become a primcipal target of the U.S. Senate's Select Committee on Improper Activities in the Labor or Management Field (the McClellan Committee), ${ }^{494}$ which formally leveled at him forty-eight specific charges of misconduct. ${ }^{495}$ Though he had recently been acquitted in one criminal

490. See infra at text accompany notes 573-609.

491. Cunningham v. English, 175 F. Supp. 764 (D.D.C. 1958), aff'd, 269 F.2d 517 (D.C. Cir. 1959), aff'd as modified, 269 F.2d 539 (D.C. Cir. 1959), cert. denied, 361 U.S. 905 (1959).

492. This subsection is drawn in substantial part from Goldberg, supra note 162 . The author would like to thank the Clerks' Offices of the U.S. District Courts for the District of Columbia and Western District of Pennsylvania for making available to him eleven boxes of original files from Cunningham v. English, the Board of Monitors litigation.

493. Beck had been thoroughly discredited by the McClellan Committce and was later convicted of tax evasion and embezzling union funds. The conviction for tax evasion was later overturned on the grounds that embezzled funds are not taxable. See J. HuTCHINson, supra note 34, at 333-34; $R$. JAMES \& E. JAMES, supra note 2, at 19-20 n.*.

494. The McClellan Committee began its liearings on February 26, 1957, and over the ncxt two years it took testimony from over 1500 witnesses during 270 days of public testimony. Thirty-four of the fifty-eiglit volumes of testimony generated at these hearings were devoted to the Teamsters union. See J. BELLACE \& A. BERKowITZ, supra note 87, at 3 \& n. 10.

495. See Senate Committee's "Indictment" of Hoffa, 40 L.R.R.M. (BNA) 37 (1957). See also INTERIM REPORT OF THE SELECT COMM. ON IMPROPER ACTIVITIES IN THE LABOR OR MANAGEMENT Field, S. ReP. No. 1417, 85th Cong., 2d Sess. 249-54 (1958) [hereinafter MCClellan CoMMITTEE INTERIM REPORT]; SECOND INTERIM REPORT OF THE SELECT COMMITTEE ON IMPROPER Activities in the Labor or Management Field, S. Rep. No. 621, 86th Cong., 1st Sess. 106-13 (1959) [hereinafter MCCLELLAN COMMITTEE SECOND INTERIM REPORT]; FINAL REPORT OF THE Select CoMmittee on IMPRoper ACtivities in the Labor or MANAGement Field, S. ReP. 
prosecution, he was facing trial on new charges in the fall. 496 These events led the Executive Council of the AFL-CIO to announce that Hoffa's election to the IBT presidency would precipitate the Teamsters' expulsion from the Federation. 497 Taking no chances, Hoffa set out to guarantee his election by stacking the convention with almost 500 illegally selected delegates under his control. ${ }^{498}$

Ten days before the IBT convention started, however, thirteen New York area Teamsters filed an action seeking to remedy Hoffa's violations of the IBT constitution by enjoming the convention and obtaining the appointment of "a master or several masters in equity" to supervise honest elections of delegates and then to supervise the election of national officers at a properly constituted convention. ${ }^{499}$ District Court Judge F. Dickinson Letts issued a temporary restraining order, but it was stayed pending appeal. .00 The convention took place as scheduled, and to no one's surprise, Hoffa was elected.

Two weeks later, the plaintiffs filed an amended coinplaint, seeking to prevent Hoffa and his slate from taking office and still attempting to place the union into some form of receivership. ${ }^{501}$ This time they met with greater success. The plaintiffs presented to the court evidence obtained from the McClellan Committee showing that the convention had been rigged. ${ }^{502}$ On the day before Hoffa was to take office, Judge Letts issued a preliminary injunction barring Hoffa from taking office until the plaintiffs' election challenge could be heard on the merits. ${ }^{503}$

No. 1139, 86th Cong., 2d Sess. pt. 3, 723-31 (1960) [hereinafter MCClellaN CommitTee Final REPORT].

496. See C. MOLLENHOFF, supra note 7, at 192-200, 205-15; W. SHERIDAN, supra note 7, at 47. 497. See Teamsters Told to Get Rid of Corrupt Officers, 40 L.R.R.M. (BNA) 44, 44 (1957); Report of AFL-CIO Committee on Teamsters Union, 40 L.R.R.M. (BNA) 46, 57, 64 (1957).

498. Evidence in the subsequent litigation indicated that compliance with the union's constitution would have disqualified a majority of the convention's delegates. Cunningham v. English, 41 L.R.R.M. (BNA) 2022, 2024-25, 2029 (D.D.C.), modified on other grounds, 41 L.R.R.M. (BNA) 2044 (D.C. Cir. 1957).

499. Complaint at 23, Cunningham v. English, Civ. No. 2361-57 (D.D.C. filed Sept. 19, 1957) [hereinafter Complaint]. Named as defendants were the IBT and its twelve International officers, including Beck and Hoffa.

500. Cunningham v. International Bhd. of Teamsters, 40 L.R.R.M. (BNA) 2650 (D.D.C.), stayed, 40 L.R.R.M. (BNA) 2653 (D.C. Cir.), petition to vacate denied, 355 U.S. 19 (1957).

501. Amended Complaint, Cunningham v. English, Civ. No. 2361-57 (D.D.C. filed Oct. 14, 1957). The Amended Complaint sought the appointment of a "receiver or master in equity" authorized to 1) devise fair election procedures for the election of delegates to a new convention at which a fair rerun election would be held; 2) supervise compliance with the IBT constitution during the delegate selection process and the convention itself; and 3) maintain "surveillance" over the defendants' "hold-over officers," in order to ensure compliance with the IBT constitution and protect the rights of members and subordinate bodies under that constitution. Id. at 28.

502. See C. MolleNHOFF, supra note 7, at 228.

503. Cunningham v. English, 41 L.R.R.M. (BNA) 2022, 2029 (D.D.C.), modified, 41 L.R.R.M. (BNA) 2044 (D.C. Cir. 1957). 
During the trial on the merits, the union's lawyers proposed a settlenient: if the plaintiffs would let Hoffa and his slate take office on a provisional basis, the defendants would agree to the creation of a three member "Board of Monitors" to serve as a watchdog and to recomniend reforms necessary to permit a new convention, and a new election, to take place. The plaintiffs agreed, ${ }^{504}$ and the court approved a consent order to that effect on January 31, 1958.505

The Board of Monitors had a turbulent three-year existence. ${ }^{506}$ Its first three members were L.N.D. Wells, a Teamster lawyer froin Texas who was nominated by the defendants; Godfrey P. Schnidt, who was nominated by the plaintiffs and was their principal lawyer; and Nathan Cayton, a retired judge from Washington who was appointed chairman.507 The Board of Monitors had a generous budget, drawn from the IBT's treasury pursuant to the consent decree, ${ }^{508}$ and it hired its own staff of lawyers, investigators, and accountants.

The inonitors were to serve "for at least one year and thereafter until a new convention" was held and new elections of officers conducted. ${ }^{509}$ Their tasks were to: 1) draft noodel bylaws, consistent with the IBT constitution, for recommendation by the union's General Executive Board (GEB) to Teamster locals that did not have bylaws; ${ }^{510} 2$ ) review the status of Teamster locals under intra-union trusteeships and to "counsel with and make recommendations to" the GEB for lifting such trusteeships; ;11 3) "consult" with the GEB in establishing accounting and financial controls aimed at ehminating inisinanagenient of union funds; 512 and 4) "counsel with . .. and make recominendations to" the credentials coinmittee for the IBT convention that would be called at the

504. For a discussion of these settlement negotiations and the motivations behind them, see Goldberg, supra note 162, at 567-68.

505. Consent Order, Cunningham v. English, C.A. 2361-57 (D.D.C. Jan. 31, 1958), reprinted in English v. Cunningham, 269 F.2d 517, 532-35 (D.C. Cir.), cert. denied, 361 U.S. 905 (1959) [hereinafter Consent Order].

506. For some contemporaneous accounts, see Mandelbaum, The Teamster Monitorship: A Lesson for the Future, 20 FED. B.J. 125, 137-43 (1960) (the author had served on the monitorship's staff); Romer, The Teamster Monitors and the Administration of the International Union, 12 LABOR L.J. 604 (1961); Note, Monitors: A New Equitable Remedy?, 70 YALE L.J. 103, 118-24 (1960).

507. Consent Order, supra note 505, 269 F.2d at 533 I 2; Mandelbaum, supra note 506, at 127.

508. Consent Order, supra note 505, 269 F.2d at 535 ๆ 10, 12.

509. Id. at 534 ก 8.

510. Id. at 533 ๆ 4. As many as 400 Teamster locals had no bylaws. Initial Report of the Board of Moritors 10, Cunningham v. English, C.A. 2361-57 (D.D.C. Aug. 6, 1958) [hereinafter Monitors' Initial Report]. The Landrum-Griffin Act now requires affiliates of labor organizations to have constitutions or bylaws meeting certain minimum standards. Landrum-Griffin Act $\S 201$ (a), 29 U.S.C. $\S 431$ (a) (1982).

511. Consent Order, supra note 505, 269 F.2d at 534 ๆ 7.

512. Id. at 533-34 I 5. 
conclusion of the inonitorship, in order to assure that delegates to that convention would be properly selected. ${ }^{513}$

The consent order also gave the monitors something of a Public Review Board role: 514 the monitors had general power to "counsel with" the GEB and to "make recommendations upon review of appeals" pursuant to the IBT constitution, in order to imsure compliance with the rights under that constitution. ${ }^{515}$ The consent order mandated no changes in the IBT constitution, but authorized the monitors to "inake recommendations after consultation with the [GEB] for amendments . . . for proposal at the next ... convention."516 Fimally-but without expressly assigning the monitors an enforceinent role-the consent order imposed upon all Teamster officials the obligation to avoid conflicts of interest and to fulfill their official duties in accordance with accepted fiduciary standards. ${ }^{517}$ The inonitors had no powers with respect to collective bargaining, contract administration, or grievances agamst einployers. ${ }^{518}$

During the inonitorship's first few inonths, it restored autonomy to forty-one of the 109 locals that had been in trusteeship and retained an accounting firm to review the IBT's accounting procedures. ${ }^{519}$ However, as Monitor Godfrey Schmidt complained, the monitors did nothing to encourage the union's provisional officers to correct the abuses uncovered by the McClellan Committee. They failed to take any action against seven local unions identified as "trouble spots," and in general they displayed a passive and tolerant attitude toward the dilatory and uncooperative behavior of the defendants. ${ }^{520}$

All this changed in late May, 1958, when Martin F. O'Donoghue was appointed chairman following Nathan Cayton's resignation. ${ }^{521}$ The plaintiffs had opposed O'Donoghue's appointment, ${ }^{522}$ but he surprised everyone by teaming with Godfrey Schmidt to interpret the monitorship's powers broadly. He reshaped the Board of Monitors into an aggressive, alınost prosecutorial entity determined to force a total cleanup upon an unwilling IBT.

513. Id. at 535 if 9 (c).

514. See supra text accompanying notes 93-104.

515. These included the right to fair elections, the right to run for office, and the right to speak at union meetimgs. Consent Order, supra note 505,269 F.2d at 533 ๆ 3.

516. Id. at 535 If 11.

517. Id. at 533-34 ๆी 5-6.

518. See Monitors' Initial Report, supra note 510, at 3.

519. Id. at 5-7.

520. Id. at 169-93 (Supplemental Report of Member Schmidt).

521. Order, Cunningham v. English, Civ. No. 2361-57 (D.D.C. May 27, 1958).

522. O'Donoghue was a union lawyer who had represented Hoffa and the IBT during earlier stages of the litigation. See Romer, supra note 506, at 606-07. 
While conceding an absence of express language authorizing a purge of corrupt union officials, Schmidt and O'Donoghue argued that "[n]o objective is ... more eniphatically an implication of the Consent Order than the purpose to elimmate criminality and corruption (especially ... in the officials and leaders of the union) from the International Organization and its subordinate bodies." 523 Accordingly, over the repeated protests of the defendants and their designated noonitor, ${ }^{524}$ the Board of Monitors issued a stream of "Orders of Recommendation" seeking to force Hoffa and the GEB to bring up on umion charges and expel a number of corrupt officials who had been exposed by the McClellan Committee. ${ }^{525}$ The union's principal response was to establish for public relations purposes a do-nothing "Anti-Racketeering Commission" later described by Judge Letts as "a deceptive tactic to defeat and frustrate the Board of Monitors." 526

Other Orders of Recommendation challenged the procedures under which the fifty-four remaining intra-union trusteeships were to be lifted, ${ }^{527}$ and sought to postpone elections in those locals until new election rules could be agreed upon and audits of membership records could be completed. ${ }^{528}$ Still another urged that Local 107 in Philadelphia-

523. Memorandum of Member Schmidt Concerning the Written Dissent of Member Wells From Orders of Recommendation Numbered 16 and 17, Voted by a Majority of the Board of Monitors at 1, Cunningham v. English, Civ. No. 2361-57 (Oct. 3, 1958) [hereinafter Schmidt Memorandum]. In support of this interpretation, Schmidt cited not only the defendants' agreement to eliminate financial conflicts of interest and abide by accepted fiduciary standards, Consent Order, supra note 505, 269 F.2d at 533-34 If 5-6, but also Hoffa's 1957 pledge to the McClellan Committee that if elected General President he would clean up the union. Schmidt also relied on 1BT lawyer Edward Bennett William's 1958 testimony before the same Committee in which he stated that the monitors had " "been given the jurisdiction ... to police intra-union democracy." Schmidt Memorandum, supra, at 2-4. As Schmidt explained, "The Monitors could have no genuine jurisdiction to police intraunion democracy if they had no power to eliminate gangster domination and corruption from the union." Id. at 4.

524. See, e.g., Memorandum of Member Wells Concerning Issuance of Orders of Recommendation Nos. 16 and 17, Cunningham v. English, Civ. No. 2361-57 (Sept. 17, 1958).

525. Among those targeted was International Vice President Owen B. Brennan, a close friend of Hoffa's who, along with Hoffa, had been implicated by the McClellan Committee in a scam to receive employer payoffs through their wives' interests in a trucking company. See Order of Recommendation No. 16 (Aug. 15, 1958), Cunningham v. English, Civ. No. 2361-57 (D.D.C. Sept. 17, 1958).

526. Findings of Fact and Conclusions of Law at 67, Cunningham v. English, Civ. No. 2361-57 (D.D.C. Feb. 9, 1959) [hereinafter Findings of Fact]; see also W. SHERIDAN, supra note 7, at 84-87, 105.

527. For example, complaints from several locals under trusteeships where elections were to be held revealed that many members-in one local, all but thirty-one of 3000 members-were denied the right to run for office because of technical difficulties in complying with requirements concerning the timely payment of their dues. See Findings of Fact, supra note 526, at 12.

528. See, e.g., Order of Recommendation Nos. 11 \& 20 (June 27, 1958 and Aug. 19, 1958), Cunningham v. English, Civ. No. 2361-57 (D.D.C. Sept. 17, 1958). 
then the IBT's fifth largest affiliate ${ }^{529}$ - be placed in an intra-union trusteeship because of the extensive corruption exposed by the McClellan Committee. ${ }^{530}$ The defendants delayed or refused comphance with most of these recommendations in what Judge Letts later found to have been a "bad faith" effort to "prevent[] the Momitors fronı carrying out the basic purposes of the Decree." 531

When the momitors learned of a plan by defendants to call a convention and hold new elections im early 1959, they sought a modification of the consent order to block the proposed convention and a general clarification of the Board of Momitors' powers. ${ }^{532}$ In Deceniber of 1958, Judge Letts complied by nodifying the consent order to require prior court approval before any new convention could be held and authorizing the monitors to undertake "a general housecleaning" of the union. ${ }^{533}$

Six months later, the court of appeals affirmed. ${ }^{534}$ It held that changed circumstances justified the district court's nodification of the consent order ${ }^{535}$ and concluded that the consent order imposed "definite obligations upon the defendants" to clean up the union. ${ }^{536}$ By this time, however, the monitorship was almost eighteen months old, and because the district court's modification of the original consent order had been stayed pending appeal, ${ }^{537}$ no nieaningful housecleaning had yet taken place. Even after the monitors' vindication in the court of appeals, the

529. See S. ROMER, THE INTERNATIONAL BROTHERHOOD OF TEAMSTERS: ITS GOVERNMENT AND STRUCTURE 4 (1962).

530. See MCClellan Committee SeCOND INTERIM REPORT, supra note 495, at 377-517; Order of Recommendation No. 4 (June 13, 1958), Cunningham v. English, Civ. No. 2361-57 (D.D.C. Sept. 17, 1958).

531. Findings of Fact, supra note 526, at $15,16$.

532. Petition for Construction, Reformation and/or Modification of the Consent Decree and for Instructions and Orders of Compliance, Cunningham v. English, Civ. No. 2361-57 (D.D.C. Sept. 17, 1958).

533. Cunningham v. Enghsh, 175 F. Supp. 764, 767-69 (D.D.C. 1958), aff'd, 269 F.2d 517 (D.C. Cir.), aff'd as modified, 269 F.2d 539 (D.C. Cir.), cert. denied, 361 U.S. 905 (1959). The court ruled that all powers "reasonably necessary to effect the basic purposes of the order are implied and available" to the monitors as "officers of the Court." Id. at 767-68.

534. English v. Cunningham 269 F.2d 517, 517 (D.C. Cir.) aff'd as modified, 269 F.2d 539 (D.C. Cir.), cert. denied, 361 U.S. 905 (1959).

535. Id. at 523.

536. Id. at 522. While it was understood that the monitors could not "command," id. at 522, they could make recommendations related to the defendants' obligations under the order and report any failures to comply to the district court. The district court, in turn, could order the defendants to take "any necessary action within the scope of its decrees," including the investigation and discipline of corrupt union officials. Id. at 525, 528.

537. See id. at 520. The defendants had agreed, however, to postpone any convention during the pendency of their appeal. Id. at 524. 
nionitors' efforts to force the defendants to rid the union of corrupt officials met with only empty promises and endless foot-dragging. ${ }^{538}$

In September, 1959, following Hoffa's refusal to bring charges against several union officials, including Local 560's Tony Provenzano, ${ }^{539}$ the inomitor decided to challenge Jinmy Hoffa himself. They issued an Interim Report charging Hoffa with mismanaging the funds of his home local in Detroit and sought an order removing Hoffa from office on the ground that he had breached his fiduciary duties under the consent order. ${ }^{540} \mathrm{~A}$ hearing on their charges never took place, however, because during the course of an imaginative and seemingly endless series of legal maneuvers, ${ }^{541}$ the court of appeals ruled that the consent order did not authorize "the District Court itself to select or reniove officers." 542

Meanwhile, the monitorship steadily disintegrated as a result of bitter infighting among the monitors and among the plaintiffs. Three months into the monitorship, for example, one of the plaintiffs split off from the rest and, joining the Hoffa camp, petitioned for Schmidt's removal as monitor. ${ }^{543}$ While evidence exists that Hoffa bought and paid for this defection, ${ }^{544}$ it is also true that the conflict of interest charges against Schmidt had merit. Schmidt was primarily a management labor lawyer, and he continued to represent some trucking conipanies in their dealings with several Teainster locals after becoming a monitor. ${ }^{545}$

538. For example, the IBT conducted a perfunctory investigation of Philadelphia's Local 107 but refused to impose an intra-union trusteeship, despitc the overwhelming evidencc of corruption that had been uncovered by the McClellan Committee and the Board of Monitors themselves. See Permanent Subcomm. on Investigations, Senate Comm. on Gov't Operations, James R. HoFfa aNd CONTINUEd UNDERWORLd CONTROL OF NEW YORK TEAMSTERS LOCAL 239, S. REP. No. 1784, 87th Cong., 2d Sess. 31-36 (1961).

539. See id. at 29.

540. Interim Report at 5-6, Cunningham v. English, Civ. No. $2361-57$ (D.D.C. Sept. 14, 1959). Monitors O'Donoghue and Lawrence T. Smith, who had rcplaced Schmidt as the plaintiffs' monitor on July 13 , see infra text accompanying note 547 , signed the Interim Report. Daniel B. Maher, who had replaced Wells as the defendants' monitor on March 18, issued a separate report dissenting in most respects from the Interim Report. Separate Report of Monitor Maher to Interim Report of the Majority Filed September 14, 1959, Cunningham v. English, Civ. No. $2361-57$ (Oct. 9, 1959).

541. See Goldberg, supra note 162 , at 576-77.

542. Hoffa v. Letts, 282 F.2d 842, 845 (D.C. Cir. 1960) (dictum).

543. Petition of John Cunningham for Removal of Godfrey P. Schmidt as Monitor, Cunningham v. English, C.A. No. 2361-57 (D.D.C. Apr. 28, 1958) [hereinafter Cunningham Petition].

544. See Hearings before the Permanent Subcomm. on Investigations of the Senate Comm. on Gov't Operations, 87th Cong., 1st Sess. 140, 149 (1961) (testimony of Martin F. O'Donoghue) [hereinafter 1961 Hearings]; W. SHERIDAN, supra note 7, at 92, 148-49.

545. English v. Cunningham, 269 F.2d 517, 526 (D.C. Cir.), aff'd as modified, 269 F.2d 539 (D.C. Cir.), cert. denied, 361 U.S. 905 (1959). The IBT filed a similar petition, which made the additional charge that Schmidt had made public statements on the right-to-work laws that were "so adverse, inconsistent and incompatible with the position taken by all organized labor as to destroy the confidence of the members of the (IBT) in his motivations." Motion of Defendant International 
Schmidt resigned as a monitor in June, 1959,546 but his replacement, Lawrence J. Smith, was the target of similar charges. ${ }^{547}$ The monitorship never overcame this damage to its credibility. ${ }^{548}$

As Schmidt's replacement on the Board of Monitors, Snith had a nonconfrontational style that was as disapponiting to the remaining plaintiffs as O'Donoghue's prosecutorial approach had been a happy surprise. By March 30, 1960, Judge Letts concluded that Smith "did not have his heart in the assignment" and summarily dismissed hin1. ${ }^{549}$ Snith's disniissal led to a second split in the plaintiffs' ranks, as Smith and several supporters obtained a reversal of Smith's dismissal from the court of appeals. ${ }^{550}$

While Snith's status was being litigated, the defendants' monitor resigned. His replacement was William E. Bufalino, a Teamster official from Detroit.551 Bufalino was the classic fox guarding the chickens; the McClellan Committee had identified him as having close ties to organized crinie and had iniplicated him in the same abuse of umion funds for which O'Donoghue was trying to investigate Hoffa. ${ }^{552}$ Not surprisingly, Bufalino played an obstructionist role as a monitor. ${ }^{553}$

Brotherhood of Teamsters, Chauffeurs, Warehousemen and Helpers of America For Removal of Godfrey P. Schmidt as Monitor at 4-5, Cunningham v. English, Civ. No. 2361-57 (D.D.C. Sept. 29, 1958).

546. Letter from Godfrey P. Schmidt to Judge F. Dickenson Letts (June 26, 1959). Schmidt continued in the case as counsel for the remaining plaintiffs, although in April of 1960, another group of the original thirteen plaintiffs split off and retained their own counsel See infra text accompanying note 450 .

547. See, e.g., Affidavit of John Cunningham, Cunningham v. English, Civ. No. 2361-57 (D.D.C. Sept. 2, 1959); Motion of Intervenors Coar et al to Vacate the Order of Court Confirming the Appointment of Lawrence J. Smith as a Member of the Board of Monitors, Cunuingham v. English, C.A. No. 2361-57 (D.D.C. July 21, 1959).

548. See, e.g., Goffen, Monitors vs. The Teamsters, ThE NAtion, Apr. 9, 1960, at 316 This article was reprinted in the May, 1960 INTERNATIONAL TEAMSTER, the IBT magazine sent to every member.

549. See Order, Cunningham v. English, C.A. No. 2361-57 (D.D.C. May 4, 1960).

550. See Milone v. English, 282 F.2d 832 (D.C. Cir. 1960) (holding that Smith's dismissal was improperly based on ex parte representations of Godfrey Schmidt).

551. See Letter from Daniel B. Maher to Judge F. Dickenson Letts (Mar. 28, 1960); Order, Cunningham v. English, C.A. No. 2361-57 (D.D.C. May 12, 1960).

552. MCClellan CoMmittee INTERIM RePort, supra note 495, at 227, 243; MCCLELlaN COMMITTEE FINAL REPORT, supra note 495 , at 613 . Judge Letts had initially refused to accept the Bufalino nomination, calling it an insult to the court. However, when the defendants refused to make another nomination, and the continued absencc of a monitor representing the defendants became the subject of inquiry in the court of appeals, he apparently concluded that he had no alternative. See Plaintiffs' Motion for Disqualification and Removal of William E. Bufalino as Defendants' Monitor at 4, Cunningham v. English, C.A. No. 2361-57 (D.D.C. July 13, 1960).

553. See Letter from Martin F. O'Donoghue to Judge F. Dickenson Letts (July 11, 1960); W. SHERIDAN, supra note 7, at 152-55. 
The moritorship's problems were not all internal. Virtually every move the monitors made was challenged by the defendants or any of seven different groups of Teamster officials, loyal to Hoffa, who intervened or tried to intervene in the name of the union's rank-and-file. ${ }^{554}$ For a case that supposedly had settled, Cunningham generated an astounding volume of hitigation. At one point, twenty-four motions were awaiting disposition in the district court, and during the course of the nonitorship, there were no less than thirty-eight appeals to the D.C. Circuit, nine inandamus actions, and three petitions for certiorari.555 There were also a number of collateral attacks on the monitorship, ${ }^{556}$ and the union orchestrated a relentless public relations and lobbying campaign that led to the introduction in Congress of several bills that would have legislated the inonitorship out of existence. 557

All this slowed the Board of Monitors' progress to a snail's pace. For nionths on end, many projects were at a standstill pending judicial clarification of the Board's powers and composition. This opened the monitors to the charge that they, not Hoffa, were denying the membership the opportunity to elect new officers, and they, not Hoffa, were fruitlessly draining the union's treasury at a rate of $\$ 35,000$ per month..$^{558}$

By the Spring of 1960, the defendants were clamoring for a new convention and accusing the monitors of ignoring their nore mundane duties, such as drafting model bylaws and supervising the lifting of trusteeships, in their effort to "get" Jimmy Hoffa. ${ }^{559}$ Though the court of appeals denied Hoffa's petition for a writ of mandamus, it sent a clear message to Judge Letts that the inonitorship soon should end, ${ }^{560}$ in part

554. See, e.g., Dorsey v. Cunningham, 282 F.2d 842, 842 (D.C. Cir. 1960); San Soucie v. Schmidt, 282 F.2d 833 (D.C. Cir. 1960); Westenberg v. English, 278 F.2d 275, 275 (D.C. Cir. 1960); Distini v. Cunningham, 272 F.2d 528, 528-29 (D.C. Cir. 1959).

555. 1961 Hearings, supra note 544, at 147 (testiunony of Martin F. O'Donoghue); Note, supra note 506, at 119 . The subjects of these proceedings ranged from the sublime to the ridiculous. Among some of the less earthshaking matters litigated were the location of the monitors' offices and the right of the inonitors to issue press releases.

556. See, e.g., Gaw v. Highain, 267 F.2d 355 (6th Cir.), cert. denied, 360 U.S. 933 (1959); Thomas v. O'Donoghue, C.A. 60-303-F (D. Mass. 1960); Quirk v. O'Donoghue, C.A. No. 2863 (D.R.I. 1960); Grace v. International Bhd. of Teamsters, C.A. No. 3949 (Pa. Common Pleas 1959); Sunith v. International Bhd. of Tcainsters, C.A. No. 34, 875 (Tenn. Ch. Ct. 1958) .

557. See, e.g., H.R. 11,845, 86th Cong., 2d Sess. (1960); S. 3444, 86th Cong., 2d Sess. (1960).

558. See Mandelbaum, supra note 506, at 139.

559. See, e.g., Defendants' Motion for a Convention, Cunningham v. English, C.A. No. 2361-57

(D.D.C. Mar. 31, 1960).

560. Another year has passed and it now appears that the desirability of early transition from court supervision to normal organizational management' ... is not being realized .... It is not clear to us that a new convention inust await compliance with all defendants' obligations under the Consent Decree... ; that is, that all those obligations nccessarily relate to the ability of the membership to elect their officers with reasonable assurancc such election would accord with their rights under the Teamsters' constitution.

Hoffa v. Letts, 282 F.2d 842, 846-47 (D.C. Cir. 1960). 
because the recently enacted Landrum-Griffin Act had mandated most of the reforms which the Board of Monitors liad been establislied to facilitate. 561

Even before that ruling, lowever, the Board of Monitors had collapsed. Martm O'Donoghue had resigned in frustration, ${ }^{562}$ and the parties were unable to agree on a replacenient. Judge Letts attempted to appoint a replacement over the defendants' objections, but the court of appeals overturned the appoimtment. ${ }^{563}$ Judge Letts therefore convened a September, 1960 settlement conference for "an earnest effort" to resolve all outstanding matters. ${ }^{564}$ By the end of the year, the parties reached an agreement regarding proposed model bylaws, release of locals still $\mathrm{m}$ trusteeship, rules for the nomination and election of convention delegates, and proposed amendments to the IBT constitution. ${ }^{565}$ No further efforts were taken to oust Hoffa or his corrupt associates from the union. On February 28, 1961, the Board of Monitors was formally dissolved.566 At an IBT convention held four months later, Jimmy Hoffa won reelection as General President. 567

Despite its probleins, the Board of Monitors accomplislied some important changes in the Teamsters union. The montors liberated over one-hundred Teamster locals from intra-union trusteeships; supervised adoption of new accounting and auditing procedures; drafted model bylaws for the many locals that liad none; and at least for a short time, offered union members a Public Review Board-type entity to which they could appeal unfair disciplinary rulings. Although passage of the Landrum-Griffin Act would liave brought about inany of these reforms, none of the parties could liave anticipated such legislation when the momitorslip began.

Nevertlieless, the Board of Monitors obviously failed to accomplish a fundamental cleanup of the union. Several reasons account for that failure: a poorly drafted consent agreement that resulted in too mucl uncertainty over the monitors' powers and too many opportunities for the defendants to swamp the monitors witli legal cliallenges; 568 the failure of the plaimtiffs' lawyers and momitors to avoid conflicts of interest,

561. Id. at 847 .

562. Letter from Martin F. O'Donoghue to Judge F. Dickenson Letts (July 11, 1960).

563. English v. McFarland, 285 F.2d 267 (D.C. Cir. 1960).

564. Letter from Judge F. Dickenson Letts to Edward Bennett Williams, et al. (Aug. 8, 1960).

565. See Stipulation, with Exhibits, Cunningham v. English, C.A. No. 2361-57 (D.D.C. Dec. 9, 1960).

566. Order, Cunningham v. English, C.A. No. 2361-57 (D.D.C. Feb. 28, 1961).

567. W. SHERIDAN, supra note 7, at 177-80. Hoffa held office until 1967, when he began serving a federal prison sentence following his convictions for jury tampering and, perhaps ironically, the same abuse of union funds for which the Board of Monitors had sought his removal. See id. at 413.

568. See supra text accompanying notes 554-58. 
which created a "union busting" appearance exploited by Hoffa to undermine the monitorship's credibility; ${ }^{569}$ and ironically, the passage of the Landrum-Griffin Act, which the court of appeals perhaps too quickly assumed would solve the problems the Board of Monitors had been established to address. ${ }^{570}$ In addition, Judge Letts, perhaps out of frustration with the defendants' recalcitrance, exhibited a rashness in soine of his rulings that led to a nuinber of reversals by the court of appeals, further slowing the monitorship's progress and fueling the defendants' resistance.

A final reason for the Board's failure to clean up the union was the absence of an organized rank-and-file movement which could use the political openings created by the monitorship to further reform the union. No inatter what procedural or structural reforms the union finally might have adopted, they would have hittle inipact unless utilized by credible, rank-and-file reformers seeking to beconne delegates to IBT conventions, or ruming for office in Teanister locals. ${ }^{571}$ The Board of Mointors, of course, cannot be blanied for the absence of a stronger rankand-file inovernent in Hoffa's Teansters union. After all, Hoffa was a genuinely charisniatic and effective leader, and the econonic booin of the period undoubtedly contributed to the ineinbership's coinplacency. ${ }^{572}$ And then, as now, the ever present danger of econonic or physical retaliation against those who chose to speak out reinforced inembership coinplacency.

- In the end, the Teamsters Board of Monitors represents a tragically inissed opportumity for what could have been a fundainental reform of one of the nation's most important unions. Thirty years later, another such opportunity is at hand, and it is to that we now turn.

\section{B. Reorganization by Decree: The Teamsters' RICO Settlement}

In June, 1988, the United States Departnient of Justice filed its long anticipated civil RICO action against the International Brotherhood of Teamsters. ${ }^{573}$ It sought 1) the reinoval of any IBT General Executive

569. See supra text accompanying notes 543-50.

570. See supra text accompanying notes 560-61.

571. Moreover, with little input from rank-and-file reformers who knew froin experience the obstacles to effective participation in union affairs-and with all too much input from Teamster officials like Monitor William Bufalino, who knew precisely how to block effective membership participation when they wanted to-even the best intentioned of lawyers would have had difficulty drafting bylaws or constitutional aunendments to maximize the potential for such participation.

572. See generally Raskin, supra note 78, at 15 .

573. United States v. International Bhd. of Teamsters, 88 Civ. 4486 (S.D.N.Y. filed June 28, 1988). In addition to the union itself, the defendants named in the complaint included the IBT's eighteen top officers, who comprised its General Executive Board (GEB), "the Commission of La Cosa Nostra," and twenty-six of its key members. Complaint at 5-6, United States v. International 
Board members, mcluding the General President, found to have committed RICO violations, 2) the appoimtment of a trustee empowered to discharge the GEB's duties, other than those related to collective bargaining or Teamster political activities, and 3) new elections of International officers in a manner that would protect against intimidation or other iniproper influences. ${ }^{574}$

The factual allegations and legal theories advanced by the complaint closely resembled those im the Local 560 hitigation, ${ }^{575}$ but on a larger scale. The government alleged that the IBT was "a captive labor organization" that had been infiltrated, exploited, and controlled by "La Cosa Nostra" (LCN or Mafia) through its control of key affiliates, mcluding Local 560 before its RICO trusteeship, and through its direct control over the IBT's top officers. The government further alleged that the LCN engineered the selections of Roy Williains and Jackie Presser as IBT presidents. ${ }^{576}$ According to the government, the union's top officers allegedly aided and abetted LCN at almost every turn. Far from taking steps to rid the union of corruption, these officers repeatedly and knowingly appointed persons with criminal records to high office and approved the direct use of violence and intimidation against union reformers. ${ }^{577}$ As summarized in a Justice Department brief:

[T]he IBT leadership has made a devil's pact with La Cosa Nostra. La Cosa Nostra figures have insured the elections of the IBT' top officers... In return, union officers have allowed La Cosa Nostra ready access to umion funds and jobs and free reign over certain IBT Locals, which $\mathrm{La}$ Cosa Nostra figures have used as instrumentalities to extort monies from einployers. Thus, the IBT's leaders get their union officers, and $\mathrm{La}$ Cosa Nostra figures get their inoney-all to the detriinent of union inembers, victimized businesses and the general public. 578

Because the governnient already had proven many of its allegations in prior cases, it immediately sought, without even an evidentiary hearing, a preliminary injunction to appoint pendente lite "court haison officers" with the power 1) to discipline pursuant to the IBT constitution corrupt or dishonest Teamster officers, members, or employees, and to

Bhd. of Teamster, 88 Civ. No. 4486 (S.D.N.Y. June 28, 1988) [hereinafter Complaint]. News that the suit was being planned had leaked from the Justice Department a year earlier. See Werner, U.S. Seeks Control of Teamster Union, N.Y. Times, June 11, 1987, at A19, col. 1.

574. Complaint, supra note 573, at 110-12.

575. See supra text accompanying notes 364-425.

576. Complaint, supra note 573, at 31-39. Both Presser, who had been an FBI informant for several years, and Williams provided the government with evidence supporting this claim. See Lubasch, supra note 11, at 1, col. 3; Serrin, supra note 8, at 1, col. 5.

577. Complaint, supra note 573.

578. Government's Memorandum of Law in Support of its Motion for Preliminary Relief 9, United States v. International Bhd. of Teamsters, 88 Civ. 4486 (S.D.N.Y. June 28, 1988). 
impose intra-union trusteeships over corrupt locals; and 2) to review proposed GEB actions regarding expenditures, appointinents, and changes in the union constitution and bylaws. 579 District Court Judge Edivard Edelstein, noting that the case was, "to say the least, unique; if not in substance, then in scope," properly concluded that it would be "iniprudent" to grant such relief without an evidentiary hearing; he did, however, agree to expedite a consolidated trial on the merits. ${ }^{580}$

On Marcl1 13, 1989, hours before the trial was to begin, the government and the umion defendants entered into a consent order of inonumental significance to both the labor moveinent and the battle against organized crime. ${ }^{581}$ The government's principal concession was that the mdividual defendants then loolding union office, ${ }^{582}$ including IBT General President Williant J. McCarthy, ${ }^{583}$ can renain in office until elections are lield in 1991. In exchange, federal prosecutors obtained a fundaniental reorganization of the IBT's governing structure and electoral process, and the judicial appoimtment of three "Court Officers" to oversee the union's operations-an Administrator, an Investigations Officer, and an Election Officer. ${ }^{584}$ The Administrator has the power of the IBT president and GEB, pursuant to the IBT constitution, to renove from office, expel, or otherwise discipline corrupt officers and inembers,

579. See Complaint, supra note 573, at 107-08.

580. Order at 4-5, United States v. International Bhd. of Teamsters, 88 Civ. 4486 (S.D.N.Y. July 7, 1988). The court did, however, continue a restraining order it had entered on June 28,1988 , enjoining LCN defendants from having any dealmgs with the IBT and enjoining the union defendants from engaging in any racketeering activities or from associating with LCN. Id. at 5-6; Order to Show Cause and Temporary Restraining Order at 7-8, United States v. International Bhd. of Teamsters, 88 Civ. 4486 (S.D.N.Y. June 28, 1988).

581. A factor that undoubtedly contributed to the union defendants' decision to settle the case was the government's effort to prevent the IBT from paying the individual defendants' legal expenses. See Government's Memorandum of Law in Support of Order to Show Cause at 8-10, United States v. International Bhd. of Teamsters, 88 Civ. 4486 (S.D.N.Y. Mar. 8, 1989).

582. Several of the GEB defendants had previously resigned their union posts and entered into separate consent judginents with the government. See DAlly LAB. REP. (BNA), Feb. 2, 1989, at A-1.

583. On July 15, 1988, following Jackie Presser's death, the GEB elected McCarthy General President by a 9-to-8 vote. Previously an IBT Vice President from the Boston area, McCarthy has never been charged with a crime, and his home local is considered free from corruption. On the other hand, he has shown an intolerance for dissent and is alleged to have sought clearance from the Mafia to seek high union office. See Butterfield, Arlington Man Elected President of Teamsters, Boston Globe, July 16, 1988, at 1, col. 1; Levin, Teamster Dissidents Seek Peace With Chief, Boston Herald, July 31, 1988, at 35; Raab, Top Teamster Informer Told F.B.I. That McCarthy Asked Mafia Help, N.Y. Times, Mar. 17, 1989, at 1, col. 4.

584. Order, United States v. International Bhd. of Teamsters, 88 Civ. 4486 (S.D.N.Y. Mar. 13, 1989) [hereinafter Consent Order]. These court officers were given the authority to retain any consultants and hire any staff necessary for the discharge of their duties. Id. at 16-17. 
and to inpose intra-union trusteeships over corrupt affiliates. ${ }^{585}$ The Adininistrator is also empowered to review and veto any IBT expenditures, appointments, or contracts (other than collective bargaining agreements) that appear to further acts of racketeering or the association of the union with La Coas Nostra. ${ }^{586}$ The Investigations Officer, with broad discovery powers, has the authority to investigate corruption within the umion and to press union disciplinary charges against wrongdoers. ${ }^{587}$

The consent order's most innovative, and in the long run perhaps most iniportant, provisions mandate dramatic changes in the way the IBT's top officers will be elected, beginning with the 1991 elections. ${ }^{588}$ For the first tine, the IBT's General President and entire GEB will be elected by secret ballot vote of the membership, and not by the open ballot votes of convention delegates who in the past have been either part of the IBT hierarchy or vulnerable to pressure from it. ${ }^{589}$ A reform long sought by Teamster dissidents, direct elections will not only force the

585. Prior to instituting trusteeship proceedings, the Administrator is required to give the International officers notice and an opportunity to take action on their own or contest the need for any action at all. The Administrator's disciplinary rulings can be appealed within fourteen days, to the district court. Id. at 7-9. That period may be too short, however, particularly for officers or menibers who live far from New York or who want to retain counsel to handle their appeals. Moreover, in reviewing the Administrator's actions, whether disciplimary or not, the court is to "apply the same standard of review applicable to review of final federal agency action under the Administrative Proeedure Act." Id. at 25 . That highly deferential standard of review obviously will streamline the remedy's operation, although possibly at the risk of endangering the rights of third parties. (The author thanks Paul Alan Levy for identifying this problem.)

586. Id. at 10-11. Such vetos are appealable to the district court.

587. Id. at 7-8, 11-12.

588. Id. at 13-16. One leading labor journalist called these changes "a revolution in Teanister annals." Raskin, The Teamsters Take It on the Chin, N.Y. Tiunes, Mar. 17, 1989, at A35, col. 1.

589. Consent Order, supra note 584. Consider the following description of Teamster "democracy":

To get a better picture of how Teamster "democracy" work[ed], imagine what our political system would look like if it operated like the Teamsters: The only public officials elected by the people would be local office holders hike mayors and city council niembers. All other public officials, including governors and the president, would be elected at conventions of these local officials.

Inagine further that power were highly centralized, so that local officials couldn't repair roads, enact zoning ordinances or otherwise handle local affairs without the express or tacit approval of the governor or the president. Indeed, coniniunities where local leaders opposed state or national policy would lose all state and federal funds, and nuunicipal boundaries could even be redrawn at will to punish dissident mayors.

In addition, assume that all votes taken at national conventions-which, incidentally, would have the power to amend the Constitution without any subsequent ratification proeedures-were by open ballot, so incunibent national officers would know exactly who supports them and who has the tenierity to oppose them. Finally, for good measure, mix in an occasional murder or disappearance of political opponents, and the somewhat more frequent beatings, and loss of jobs, of dissident activists.

Given such a political system, we would not be surprised to see the development of an entrenched, autocratic and self-perpetuating national leadership, completely beyond the 
hierarchy to be more responsive to the rank-and-file, it also will make it harder for LCN to influence the outcome of the vote. ${ }^{590}$

Candidates for International office will be nominated by secret ballot votes of delegates to the IBT convention-delegates who, for the first time in thirty years will be elected by the membership shortly before the convention. ${ }^{591}$ Moreover, eleven of the sixteen International Vice Presidents for the first time will run for office on a regional, rather than an atlarge, basis. ${ }^{592}$ This decentralization of power within the union should make LCN control more difficult and will promote imternal democracy by enabling potential challengers of the International hierarchy to develop independent bases of pohtical strength. ${ }^{593}$

control of the electorate. Unfortunately, the Teamsters government work[ed] almost exactly this way, with the predictable results.

Goldberg, Teamsters: More Oligarchy Than Democracy, Philadelphia Inquirer, May 23, 1983, at 11 A (op-ed page). See also PROD, TEAMSTERs DEMOCRACY AND FinanCial Responsibility 1-45 (A. Fox \& J. Sikorski eds. 1976).

590. See, e.g., Connolly, Why Not Try Union Democracy?. The Nation, Sept. 5, 1987, at 192; Geoghegan, Union Suit, NEw Republic, Aug. 22, 1988, at 14; Paff, Let the Teamsters Vote, Wash. Post, June 21, 1987, at B5, col. 2. For years, "Direct Election of Officers" has been included in the "Rank \& File Bill of Rights" promoted by Teamsters for a Democratic Union and reproduced in almost every issue of their newspaper, Convoy-Dispatch. See also TEAMSTERS FOR A DEMOCRATIC Union, The Teamsters UnION: New Directions For THE 1980's 11 (1981) [hereinafter New Directions]. For discussion of the advantages and disadvantages of the referendum and convention methods of electing union officers, see J. EDELSTEIN \& M. WARNER, supra note 81, at 76-79; James, supra note 82, at 261-62.

591. Consent Order, supra note 584, at 13-14. In the past, only a small percentage of delegates were elected in special elections on the eve of the convention; most delegates were officers of Teamster locals and were automatically delegates by virtue of their election to local office. This change is also one long sought by Teamster reformers, who argue that election by the membership on the eve of the convention is more democratic for two reasons. First, it focuses the electorate's attention directly on national union issues, particularly the campaign for national office; voting for local officers, on the other hand, can take place up to three years before an IBT convention and usually focuses on local issues. Second, the pool of credible candidates for convention delegate positions is typically larger than the pool of candidates for local union office, since a candidate running for office on an otherwise attractive platform might lose because he lacks administrative experience, while a similar candidate running only for a convention delegate position would probably not be as disadvantaged.

TDU had argued, without suceess, that the IBT's refusal to hold special delegate elections violated the Landrum-Griffin Act. See Theodus v. McLaughlin, 852 F.2d 1380 (D.C. Cir. 1988); Rulemaking Petition of Teamsters for a Democratic Union and Association for Union Democracy, Filed with the Department of Labor, Aug. 9, 1985, reprinted in DaILy LAB. REP. (BNA), Aug. 13, 1985, at D-1. See generally Levy, Electing Union Officers Under the LMRDA, 5 CARDozo L. REv. 737, 812-21 (1984).

592. Consent Order, supra note 584, at 13.

593. See J. EDELSTEIN \& M. WARNER, supra note 81, at 319; Gamm, The Election Base of National Union Executive Boards, 32 INDUS. REL. 295 (1979). According to some Teamster reformers, however, the large size of the electoral regions somewhat undercuts the benefits of this reform: "We would have preferred having smaller regions like the UAW or most other unions. But this is still an enormous opening for the membership." Moody, Teamsters Win Right to Vote, Labor Notes, Apr., 1989, at 1, 11 (quoting TDU organizer Ken Paff). 
The terms of the Administrator and Investigations Officer will expire following the 1991 election, but the Election Officer also can supervise the next election, in 1996.594 Following the 1991 election, the union will establish an Independent Review Board with power to investigate and remedy corruption within the union and to review, and if necessary overturn, any disciplinary or intra-union trusteeship decisions of the GEB. 595 All expelises related to the consent order's implennentation will be paid by the union. ${ }^{596}$ Until the 1991 convention, the IBT constitution will be "deenied amended" in any inanner necessary to coinply with the new election procedures or other terms of the consent order; at the 1991 convention, the IBT "shall" formally adopt the necessary aniendnients. ${ }^{597}$ Any subsequent changes in IBT practices covered by the consent order are subject to a Justice Departinent veto, reviewable in federal court. ${ }^{598}$

It is impossible to predict whether changes inandated by the 1989 consent order will succeed in cleaning up the Teanisters uinon where previous efforts have failed. Certainly, inuch will hinge on the abilities of the three individuals appointed to serve as Adininistrator, Investigations Officer, and Election Officer, and as of this writing, the court has not yet inade those appointinents. Nevertheless, the 1989 reorganization has a greater chance of success than the monitorship had a generation ago. In part, this is because the powers of the three court officers are substantially greater than were those of the moiritors. In addition, the consent order reflects a more sophisticated understanding of how the union works and what kinds of structural changes are necessary to proinote union democracy and reduce the opportunities for mob infiltration. Finally, the consent order's electoral reforms provide the umion's ineinbership with their first real opportunity to clean up their union for theinselves, at a tine when organized pressure froin below and splits at the top ${ }^{599}$ nake that result a genuine possibility for the first tine in fifty years.

This is not to say that the consent order is a perfect docunient. For exainple, voting in the 1991 elections will apparently be "by in-person

594. Consent Order, supra note 584, at 3,15.

595. Id. at 18-23. One member of the three-person Board will be appointed by the Attorney General, a second by the IBT, and the third by the two appointed Board members.

596. Id. at 17.

597. Id. at $4-5,23,25$. If the amendments are not adopted, the government "retains the right to seek any appropriate action, including enforcement of this order, contempt or reopening this litigation." Id. at 25 .

598. Id. at 25-26.

599. See Berstein, The Feds Drive a Wedge Into the Teamsters, Bus. WeEK, Feb. 6, 1989, at 90; Top Leadership Crumbling in Time of Crisis, ConvoY DisPatch, May 1989, at 3. 
ballot box voting at local union(s)," rather than by a mail referendum. ${ }^{600}$ This approach is likely to reduce member turnout and could make policing voter intimidation more difficult. ${ }^{601}$ Moreover, while the consent order authorizes the Administrator to publish inonthly reports in the IBT magazine, ${ }^{602}$ it does not indicate whether Teanster reformers, or candidates running in IBT elections, will also have access to the union publication. ${ }^{603}$ Reform candidates may find it difficult to conipete credibly with incumbents, due both to the normal advantages of incunibency, which can be overwhelming even in honest unions, ${ }^{604}$ and to the lingernig effects of decades of intimidation against rank-and-file activism. Providing access to union publications can help level the playing field. ${ }^{605}$ Fimally, the consent order also might have prohibited union officials from holding multiple offices and from drawing multiple salaries, ${ }^{606}$ a practice that contributes to the centralization of power in a few officers at the top of the hierarchy. ${ }^{607}$

It will undoubtedly take years before any final conclusions can be reached about the consent order's effectiveness in rooting out corruption in the Teamsters union. But even before the announcenient of the settlement, there was reason for optimisin that the consent order's election reforms would make even the IBT's old guard nnore responsive to the union's meanbership: one of the first steps William J. McCarthy took

600. Consent Order, supra note 584, at 14-15. However, language providing for "absentee ballot procedures where necessary" arguably leaves open the possibility of voting by a mail referendum. Id. at 15.

601. Given the fact that there are over 700 Teamster locals, thousands of poll watchers might be necessary on the day of the election to guarantee a fair election.

602. Consent Order, supra note 584, at 16.

603. One of the remarkable features of the RICO trusteeship in Local 560 was the vigorous exchange of opinion in the letters to the editor section of the 560 Free Press, the local newspaper maugurated by trustee Ed Stier. See supra text accompanying note 403. A right of access should be implied under the Consent Order, particularly for candidates, since the Order gives the Election Officer "the right to distribute materials about the election to the IBT membership." Id. at 15.

604. See generally James, supra note 82.

605. See generally Jacobs \& Spring, Fair Coverage in Internal Union Periodicals, 4 INDUS. REL. L.J. 204, 215-32 (1981); Levy, supra note 591, at 781-87; Comment, Free Speech and Union Newspapers: Internal Democracy and Title I Rights, 20 HARv. C.R.-C.L. L. REV. 485, 485-86 (1985).

606. At the time of his death, for example, Jackie Presser held and received compensation not only for IBT office, but also for office in Teamsters Local 507, Joint Council 41, and the Ohio Conference of Teamsters. In all, almost forty top Teamster officials currently hold three or more paid union posts. See 124 Teamster Officials in \$100,000 Club, ConvoY DispaTcH, Oct. 1988, at 67.

607. This is a reform long sought by Teamsters for a Democratic Union and endorsed by Department of Labor experts on labor racketeering. See Moroney \& Barnes, The Right Way to Purge the Teamsters, N.Y. Times, Mar. 9, 1988, at A31, col. 2; NEW DirecTions, supra note 590, at 12. 
after the GEB chose him to succeed the late Jackie Presser as IBT president $t^{608}$ was to democratize the ratification process for Teamster contracts ${ }^{609}$ _just the kind of move one might expect from a man aware that his continued tenure in office might depend more on the union's membership than on the Mafia.

\section{TOWARd MAXImizing EFfectiveness While MINIMIZING INTRUSIVENESS}

This Article has surveyed a wide range of remedies for union corruption and labor racketeering and has exannined their application in many different settings. This section will syntlesize some of the lessons from those experiments in union reform litigation, in the hope that they may assist courts and lawyers involved in such cases to develop remedies that are effective in reforming corrupt unions but at the same tinie respectful of the independence of the American labor movement.

\section{A. The Politics of RICO Trusteeships}

As discussed earlier, the courts liave resolved noost of the legal questions regarding the availability of RICO trusteeships in recent labor racketeering cases favorably to federal prosecutors. ${ }^{610}$ Moreover, courts have long recognized their inherent equitable power to impose trusteeships and other forms of structural relief in institutional reforn cases arising outside the labor context, ${ }^{611}$ and those equitable powers have played a significant, if sometimes overlooked, role in the history of union reforin litigation as well. ${ }^{12}$

Opponents of RICO trusteeships, however, sometimes compare them to the recently ended suppression of the labor movement "Solidarity" by a totalitarian Pohsh government. ${ }^{613}$ Jackie Presser was by no

608. See supra note 583 and accompanying text.

609. See Teamsters Are Said to Scrap a Rule on Two-Thirds Vote, N.Y. Times, Oct. 21, 1988, at A14, col. 5.

610. See e.g., United States v. Local 560, Int'l Bhd. of Teamsters (Local 560 III), 780 F.2d 267 (3d Cir. 1985), cert. denied, 476 U.S. 1140 (1986); United States v. Local 30, United Slate, Tile \& Composition Roofers, 686 F. Supp. 1139 (E.D. Pa. 1988), aff'd, 842 F.2d 512, 513 (3d Cir. 1989);

United States v. International Bhd. of Teamsters, 708 F. Supp. 1388 (S.D.N.Y. 1989).

611. See supra text accompanying notes 117-33.

612. See supra text accompanying notes $134-200$.

613. For example, in a political advertisement entitled "Is This How the Justice Department Celebrates Independence Day?," which appeared in a July 4th edition of the New York Times a few days after the government filed its civil RICO action against the IBT, Senator Orrin Hatch is quoted as follows:

This is not Poland; this is not the Soviet Union. Our Constitution and Bill of Rights guarantee institutions the right of association, and guarantee institutions the right to exist in 
stretch of the imagination a Lech Walesa, but the analogy does emphasize an important point: the labor moveinent's freedom from government control is not only important to umions theinselves, it is also one of the most important features distinguishing the Western democracies froin inore oppressive forms of government.

Former U.S. Attorney Rudolph Giuliani was undoubtedly sincere when he disclaimed any anti-union inotivation in his efforts to inpose a trusteeship over the IBT. 614 But establishing a precedent for placing a national union into a full-blown trusteeship would create a danger that the device will be abused in other cases for the illegitimate purpose of weakening unions. The Reagan administration's 1981 destruction of the air traffic controllers' union and its overall anti-union orientation, ${ }^{615}$ as well as the judiciary's long history of hostility towards labor umons throughout the nineteenth and early twentieth centuries, ${ }^{616}$ suggest that this scenario is less far-fetched than one might hope.

Nor does a reluctant acknowledgeinent of the potential propriety of a RICO trusteeship over a hopelessly corrupt local union such as Teamsters Local 560 necessitate the acceptance of its use in cases involving national umions. The differences in scale are so great as to become qualitative. If an 8000-meinber local ${ }^{617}$ were placed into a RICO trusteeship for abusive reasons, there undoubtedly would be a chilling effect on other unions; however, the direct impact on the rest of the labor movement would be relatively sinall. On the other hand, if a national union as important as the Teamsters, which comprises nearly ten percent of the American labor inoveinent, were inproperly placed in a full-fledged trusteeship, the consequences could be devastating. Circuinstances that could justify running such a risk are difficult to iniagine.

Moreover, quite apart froin these pohicy concerns, prosecutors serious about maximizing civil RICO's effectiveness in the war against orgamized crime should be reluctant to seek RICO trusteeships on an extensive scale because of the political backlash which those remedies

our democratic society. To place an institution like the Teamsters under government control flies in the face of those Constitutional guarantees and makes us no better than the Soviets or the Poles.

N.Y. Times, July 4, 1988, at 9. The ad was sponsored by Americans Against Government Control of Umions, founded by top officials in the AFL-CIO.

614. "This lawsuit is not in any sense an attack on trade unionism or on the many, many Teamsters who are honest, hardworking people." Shenon, U.S. Sues to Oust Teamster Chiefs and Have Trustee Run the Union, N.Y. Times, June 28, 1988, at 1, col. 2 (quoting U.S. Attorney Rudolph W. Giuliani).

615. See, e.g., Levy, The Unidimensional Perspective of the Reagan Labor Board, 16 RUTGERS L.J. 269 (1985).

616. See, e.g., F. Frankfurter \& N. Greene, The Labor InJunction (1930).

617. Most umion locals are substantially smaller, with an average size of approximately 300 members. See J. WALliHaN, supra note 69, at 91. 
would engender. Even before the government filed its suit against the IBT, union lobbyists had persuaded over two hundred members of Congress to sign a letter to the Attorney General opposing a RICO trusteeship over the IBT, ${ }^{618}$ and shortly after the suit was filed, the nuinber approached 300.619 Congress has coine close on several occasions to weakening civil RICO by amendment, ${ }^{620}$ and while none of the proposals addressed the statute's equitable remedies, amendments put forwàrd in the future in all likelihood will.621

\section{B. Some Civil RICO "Sentencing" Guidelines}

Notwithstanding these political constraints on the availability of civil RICO structural injunctions im union reform litigation, situations nray arise-like that in Tony Provenzano's Teamsters Local 560-which warrant drastic remedies. This subsection offers some guidelines to litigants and courts for evaluating the propriety of seeking or imposing intrusive RICO reinedies in particular cases.

1. Seek the Least Intrusive Remedy Likely to Be Effective, and Recognize that the Most Intrusive Remedy Is Not Always the Most Effective. Rights protected by the first amendinent-particularly freedoin of association-are unavoidably implicated in union reform litigation. ${ }^{622}$ First ainendment analysis inust therefore be brought to bear. The Supreme Court has indicated that eradicating organized crime's infiltration of the labor movement may be a compelling state interest, ${ }^{623}$ but the Court has also demanded " 'precision of regulation:' " governinent " 'may not employ means that broadly stifle fundamental personal liberties when the end can be more narrowly achieved." "624

618. See Letter from William L. Clay, et al. to Hon. Edwin Meese, III (Dec. 10, 1987).

619. See Dwyer, Garland \& Berstem, Will Going After Unions Bust Up RICO?, BUS. WEEK, May 30, 1988, at 30.

620. See generally Horn, The Venue of the Debate Shifts From the Courts to the Congress, NaT'L L.J., Aug. 26, 1985, at 24; Nathan, A Call for Congressional Action to Reform RICO, Civil RICO Rep. (BNA) 4 (Feb. 9, 1988); Vise, RICO Reform Movement On a Roll, Wash. Post, Nov. 12, 1989, at $\mathrm{HI}$, col.4.

621. For a discussion of the Teamster lobbying effort, in Hoffa's day, for legislation abolishing the Teamsters Board of Monitors, see supra text accompanying note 557.

622. See supra text accompanying notes 342-61.

623. See Brown v. Hotel \& Restaurant Employees Nat'1 Union Local 54, 468 U.S. 491, 509 (1984).

624. NAACP v. Claiborne Hardware Co., 458 U.S. 886, 916, 920 (1982) (quoting NAACP v. Button, 371 U.S. 415, 438 (1963), and Carroll v. Princess Anne, 393 U.S. 175, 183-84 (1968)). One commentator proposes the application of a burden of proof higher than the preponderance of the evidence standard in determining whether a particular remedy is the least drastic alternative in a union reform case. See Comment, supra note 350, at 960-61. 
Some commentators characterize the 1989 Teamsters consent order, though arguably "precise," as a defeat for the government. The incumbent officers remain in office, and unlike the situation in Local 560, there was no full-fledged trusteeship. ${ }^{625}$ However, the most intrusive remedy is not necessarily the inost effective remedy. ${ }^{626}$ By forgoing a trusteeship over the IBT, the governinent not only avoided the political dangers outlined above, it also avoided transforming ousted IBT officers into martyrs and "freedom fighters," as it had in Local 560. Sucl1 a result may enhance the remedy's prospects for success. 627

2. An Evidentiary Hearing Must Precede the Imposition of Structural Relief. No court has yet granted intrusive structural relief in a civil RICO union reform case without first holding an evidentiary hearing, but federal prosecutors have repeatedly petitioned the courts to do so. ${ }^{628}$ Courts slionld contimue to deny such requests, both to accommodate federal labor policy as manifest in the Norris-LaGuardia Act, which expressly bars federal courts from granting labor injunctions without holding evidentiary hearings, ${ }^{629}$ and to ensure that the requested relief is not only warranted on the merits, ${ }^{630}$ but also properly tailored to the circumstances of the particular case.

3. Design Remedies That Will Promote Union Democracy. A fundamental assumption of the Landrum-Griffin Act is that the "full and active participation by the rank and file in the affairs of the union" 631 will

625. See Dionne, Teamsters and the U.S.: Love-Hate Relationship, N.Y. Times, Mar. 14, 1989, at 28 , col. 1 .

626. See generally Gewirtz, supra note 362, at 608-09 (arguing, primarily in the context of school desegregation, that limited remedies may be more effective than broader remedies because they reduce the problems posed by resistance to judically-imposed solutions).

627. To grasp the enormity of the task a court-appointed trustee would have faced in the IBT, one might multiply by factors of ten the difficulties experienced by the Local 560 trustees. (While Local 560 members comprise about one half of one percent of the IBT's entire membership, 560's level of corruption was at the 99th percentile.) Instead of one Michael Sciarra working to undermine the trusteeship, for example, there would likely have been hundreds. Any RICO trusteeship would have had to leave in place thousands of local and intermediate level union officials, and even the most honest and reform-minded among them might have been unwilling to play "quisling" to a total government takeover. It is a classic situation of "remedial success depend[ing] upon the cooperation of parties whose cooperation is not easily secured," Gewirtz, supra note 362, at $615 \mathrm{n} .79$.

628. See supra text accompanying notes $429,448,579$.

629. 28 U.S.C. $\$ 107$ (1982).

630. In the Fulton Fishmarket litigation, prosecutors who had unsuccessfully sought, prior to an evidentiary hearing, the removal from office of the defendant union's elected leadership were later unable to prove at trial that the union or its officers were sufficiently corrupt to warrant imposition of any RICO remedy whatsoever. See supra note 463.

631. American Fed'n of Musicians v. Wittstein, 379 U.S. 171, 182-83 (1964). 
"bring about a regeneration of union leadership."632 Nothing in the history of union reform litigation disproves that assumption, and much supports it. ${ }^{633}$ In unions such as the Teamsters, the Landrum-Griffin Act alone may have failed to eliminate corruption, but that failure calls into question not the need for union democracy but the nature of the reforins necessary to achieve it. Civil RICO should be applied to unions in a manner that furthers the goals of the Landrum-Griffin Act, but with the recognition that Landrum-Griffin establishes only general standards of deniocracy applicable to the labor movement at large. RICO reniedies can be tailored to the needs of the particular union and the particular case. ${ }^{634}$

Of course, overnight results cannot be expected. For decades in these unions, challengers to corrupt regimes have risked financial rum and the threat of physical assault or worse. ${ }^{635}$ In the wake of such oppression, time is necessary for reforin factions to emerge; more time is needed for challengers to gain enough credibility to win union office. RICO remedies niust encourage and facihitate their development. ${ }^{636}$

What if these efforts do not work, and the inembers vote the nob back into power? Local 560 aside, ${ }^{637}$ I do not think that will often happen if the members have a real choice. Besides, the mere risk of failure

632. 105 CONG. REC. 6472 (1959), reprinted in LMRDA LEGISLATTVE HISTORY, supra note 64, at 1099 (statement of Sen. McClellan).

633. In Local 560 , the disappointing results of the 1988 election suggest only that it is too early to judge the success of that trusteeship, not that it failed. Conditions in Local 560 today, while not ideal, are certainly better than they were when the lawsuit began or when the trusteeship went into place. And clearly the RICO remedy did not weaken the local as an effective bargaining agent for its members. See supra note $\mathbf{3 5 0}$ and accompanying text.

634. See Chayes, supra note 25 , at 1308 . For example, most national unions, including many known for their democratic traditions, elect their top officers at conventions, rather than by membership referenda, for entirely legitimate reasons. Congress, therefore, appropriately omitted from the Landrum-Griffin Act any provision making the referendum method mandatory. On the other hand, in most unions the Mafia has not exploited the convention method to take over the union the way it apparently has in the Teamsters. That being the case, a civil RICO remedy requiring direct meinbership election of IBT officers is perfectly appropriate; it goes beyond what Landrum-Griffin requires, but in a manner that promotes the goals of that Act.

635. Criminal activities temper Michels' Iron Law [of Oligarchy] into high grade steel." Comment, supra note 350 , at 940 (referring to R. Michels, Political Parties: A Sociological StUdy OF THE OligarCHICAL TENDENCIES OF MODERN DEMOCRCY (1911)).

636. For example, membership committees and stewards councils can be formed, educational and training programs established, and a union newspaper published, in an effort to promote membership involvement in union affairs. Experienced union organizers and labor educators might be brought in to assist in the implementation.

637. The "wrong" candidates won the 1988 elections in Local 560, but membership intimidation in that local had not ended completely, and opposition factions only recently had begun to emerge. It is still too early to draw any final conclusions about Local 560. See supra text accompanying notes $441-43$. 
cannot preclude the attempt. Providing union nembers with the opportunity to clean up their unions for themselves is the less drastic alternative denianded by the first aniendnient and federal labor policy.

\section{RICO Remedies Should Build Upon Internal Union Remedies.} One way RICO litigation can proniote responsible union self-government is by enhancing reniedies already provided for in union constitutions. Most unions, even corrupt ones like the Teamsters, nuake paper pronises of fair treatnient to their nienibers. ${ }^{638}$ Using RICO reinedies to enforce those promises can create in the ineinbership an expectation of conipliance with the union constitution, and can give union officers and nembers the experience with their own institutions that is necessary to proinote their continued operation after judicial supervision ends. Of course, if a union's own reinedies were working properly at the outset, no RICO reniedy would be required. Therefore, to "build upon" union reinedies in RICO cases can niean authorizmg court appointees to invoke thein, as in the IBT settleinent, or inandating the creation of new ones, such as public review boards. ${ }^{639}$

\section{The Membership's Interests Should Be Represented in Court.} In any case involving structural relief against a union, the court should assure itself that the interests of the union's rank-and-file are adequately represented, both to conply with RICO's mandate for "inaking due provision for the rights of innocent persons," ${ }^{640}$ and to obtain the benefit of the expertise and insight that rank-and-file activists might have to offer when shaping and implementing appropriate remedies. ${ }^{641}$ In a civil RICO case alleging inob infiltration and control of a union's hierarchy, the stronger that clami, the more hikely union lawyers, retained by that hierarchy, will fail to protect the nienbership's interests. ${ }^{642}$ Federal

638. See supro text accompanying notes 70-104.

639. See supra text accompanying note 595. It also might include applying the long dormant AFL-CIO Ethical Practices Codes, as the court attempted in the Roofers litigation. See supra note 478.

640. 18 U.S.C. § 1964(a) (1982).

641. See generally Note, Institutional Reform Litigation: Representation in the Remedial Process, 91 YALE L.J. 1474 (1982). In the government's case against the IBT, for example, Teamsters for a Democratic Union sought to intervene to urge the court to refrain from imposing a trusteeship, and to instead order election reforms similar to those ultimately provided for in the Consent Order. See Teamsters for a Democratic Union, Memorandum in Support of Motion to Intervene, United States v. International Bhd. of Teamsters, 88 Civ. 4486 (S.D.N.Y. Jan. 17, 1989).

642. Cf. Pope, Two Faces, Two Ethics: Labor Union Lawyers and the Emerging Doctrine of Entity Ethics, 68 ORE. L. REv. 1, 30-43, 50 (1989) (urging disqualification of union lawyers in litigation alleging union or officer violations of democratic rights or breaches of fiduciary duties); Bartosic \& Minda, Union Fiduciaries, Attorneys and Conflicts of Interest, 15 U. C. DAvis L. REv. 229 (1981) (examining use of union funds to defend union officials in litigation). 
prosecutors bringing such cases represent the public's interest in law enforcement, but do not purport to represent the interests of rank-and-file union inembers in controlling their own unions.

Courts, therefore, should freely grant motions to intervene filed pursuant to Rule $24^{643}$ on behalf of reform elements within a union targeted for RICO relief. ${ }^{644}$ If no members seek to intervene, they may be too intimidated, insufficiently organized, or lacking in resources to do so. In such cases, the court might invite amicus briefs from organizations such as the Association for Umon Deinocracy, or even employ, sua sponte, compulsory joinder pursuant to Rule 19 (a), ${ }^{645}$ witl appointed counsel to be compensated by the government or the union defendants. ${ }^{646}$

\section{Only Unions Victimized by Organized Crime Should Be Targeted} for RICO Structural Injunctions. Because RICO structural injunctions are potentially dangerous to the independence of the American labor movement, they should be available ouly against umons that have been infiltrated by organized crime, and ouly when that infiltration lias violated the membership's right to umion self-government. ${ }^{647}$ The successful elimination of serious but non-organized crime related corruption in the UMW in 1972 demonstrates that the remedies available under the Landruin-Griffin Act, when vigorously enforced, are sufficient in most other situations. ${ }^{648}$ A Mafia presence, on the other hand, makes it highly unlikely that the removal of a few corrupt individuals, witlout structural relief, will be sufficient to clean up a union. Judicial rejections of efforts to limit all applications of RICO to cases involving organized crime ${ }^{649}$ do not preclude this limitation in umon reform hitigation, since the first

643. FED. R. CIV. P. 24.

644. Members opposing structural reform also should be permitted to intervene if they can deinonstrate that their interests are not already represented adequately by the union defendants. Courts should be alert to the possibility, however, that groups of inembers may seek to intervene for the sole purpose of undermining a remedy's implementation, as occurred in the Board of Monitors litigation. See supra text accompanying notes 543-48.

645. FED. R. CIV. P. 19(a).

646. See Chayes, supra note 25, at 1311-12; Tobias, Rule 19 and the Public Rights Exception to Party Joinder, 65 N.C.L. Rev. 745, 779 n.180, 783-84, 787 n.227 (1987); cf. Laycock, Consent Decrees Without Consent: The Rights of Nonconsenting Third Parties, 1987 U. CHI. L.F. 103, 130-31; Mengler, Consent Decree Paradigms: Models Without Meaning, 29 B.C.L. REv. 291, 338-39 (1988).

647. See supra text accompanying notes 263-300; cf. Fletcher, The Discretionary Constitution: Institutional Remedies and Judicial Legitimacy, 91 YALE L.J. 635, 692 (1982) (institutional reform litigation legitimate when undertaken "to counteract ... a serious and generalized malfunctioning of the political processes").

648. This is not to say that Landrum-Griffin works perfectly in those cases. After all, it took the brutal murders of a UMW reform candidate and his family, and the political pressure those murders generated, to compel the Department of Labor to take seriously its enforcement responsibilities. See J. FinLEY, supra note 64 , at $291-92$

649. See supra note 240 and accompanying text. 
amendment and federal labor policy warrant special treatment of umions. ${ }^{650}$

7. Intrusive RICO Remedies Are Inappropriate in Cases Arising Solely Out of Traditional Labor Disputes. Again for reasons of federal labor policy, no court sliould apply intrusive RICO remedies in cases where the predicate acts ${ }^{651}$ have occurred in the context of traditional labor disputes, even if violence taints those disputes. ${ }^{652}$ Although RICO may not be totally preempted in such cases, ${ }^{653}$ courts nonetheless should exercise their discretion to reject drastic structural injunctions. The danger is simply too great tliat such structural reinedies will undermine federal labor policy by weakening the labor movement's ability to advance the legitimate imterests of the workers it represents. Less drastic criminal or civil remedies are almost always sufficient to control routine picket line violence or related misconduct in any event.

Limiting relief to less drastic criminal or civil remedies does not mean that structural relief slould be unavailable any time a RICO case involves a labor dispute; after all, organized crime often seeks to infiltrate umons precisely to use strikes or strike threats to extort payoffs fron employers. 654 In those cases, lowever, intrusive remedies slould be available ouly where there are sufficient predicate acts, unrelated to the union's legitimate collective bargaming goals, to establislı RICO liability.

8. Minimize Judical Involvement with Collective Bargaining or Union Political Activities. Where intrusive structural relief is appropriate, courts should design the remedy to minimize direct involvement by the court or the court's appointees in the union's day-to-day collective bargaining activities. Of course, any remedy affecting a union's internal affairs can have an indirect impact on collective bargaining. ${ }^{655} \mathrm{But}$ to the extent possible, contract negotiation and administration slould be left in

650. Even where no organized crime connection exists, RICO remedies could still be available against individual defendants.

651. See supra text accompanying notes 251-53.

652. By "traditional labor disputes," I mean those in which the union is seeking to defend or advance its members' legitimate interests in better wages or working conditions, as opposed to those used by corrupt union officials to extort labor peace payoffs for their own personal gain.

653. But cf. United States v. Enmons, 410 U.S. 396 (1973) (so limiting the Hobbs Act). See supra text accompanying notes 314-18.

654. See, e.g., United States v. Local 30, United Slate, Tile \& Composition Roofers, 686 F. Supp. 1139 (E.D. Pa. 1988); see supra text accompanying notes 464-66.

655. Indeed, to the extent RICO remedies democratize unions, they may enhance union militance at the bargaining table. In the Teamsters, for example, reformers have been critical of the IBT hierarchy as much for its concessionary bargaining as for its corruption and autocracy. See New D1RECTIONS, supra note 590. 
the hands of union officials, subject only to monitoring for corrupt practices. ${ }^{656}$ This approach not only comples with the mandates of federal labor pohicy, ${ }^{657}$ it also preserves the legitimacy of the RICO remedy itself by insulating it from criticism for any collective bargaining setbacks the union might suffer during the remedy's duration. As for union activities in the political arena, the first anendment all but totally bars judicial interference. 658

9. Adequate Resources Must Be Available for Implementation. Implementation of RICO remedies in union reforn hitigation can be expensive. Trustees and other court appointees must be compensated, and they may need to retain lawyers, accountants, investigators, or other staff to assist thein. Efforts to promote membership nivolveinent in union affairs, such as publication of a union newspaper or running membership training prograins, are also costly.

In large unions, the resources niay be readily available from the union itself, although there is obviously "something unsetthing about billing the victimized rank and file" for the cost of the reinedy. ${ }^{659}$ In small unions, on the other hand, particularly where corrupt officials have embezzled or misappropriated umion funds, this option may not be available, since the treasury may be unable to support the costs of an effective remedy. ${ }^{660}$

An alteruative source of funding might be monies recovered from labor racketeers through RICO's criminal forfeiture provision. ${ }^{661}$ Courts might also make remedies sought by federal prosecutors contingent on

656. Most RICO union reform litigation up to this point has taken this approach, including the recent IBT settlement. See supra text accompanying notes 581-98. The principal exception is the Local 560 case, but even in that case, Judge Ackerman, himself a veteran of the labor movement, was keenly sensitive to the need for an effective collective bargaining performance, and his trustees for the most part were able to deliver it. See supra text accompanying notes 389,402 . That will not always be the case, however.

657. See, e.g., NLRB v. Insurance Agents Int'l Union, 361 U.S. 477, 488, 490 (1960) ("Congress intended that the parties should have wide latitude in their negotiations, unrestricted by any government power to regulate the substantive solution of their differenees. . . . Our labor policy is not ... erected on a foundation of government control of the results of negotiations.").

658. However, the remedies might reach political action funds which are raised or spent illegally, for example, to bribe a pnblic official.

659. J. JACobs, Court APpointed TRusteeships: A BAckground PAPER 13 (prepared for the New York State Organized Crime Task Force, Jan. 1988).

660. This was one of the difficulties faced during the implementation of the RICO remedy in United States v. Local 6A, Cement \& Concrete Workers, 663 F. Supp. 192 (S.D.N.Y. 1986). See supra text accompanying notes 426-43.

661. 18 U.S.C. $\$ 1963(a)(1)$ (1982 \& Supp. V 1987). Civil RICO treble damages also should be sought on behalf of the victimized union, but recovery in many cases will take too long to be of much help while the RICO structural relief is being implemented. 
funding being made available by the Justice or Labor Departments. ${ }^{662}$ Unless fundmg is available in amounts sufficient to give structural relief a realistic chance of success, the compromise of first amendment rights and federal labor policy resulting from such remedies is difficult to justify.

10. The Court Must Be Committed to the Relief It Orders. Institutional reform cases typically stretch the courts' resources and abilities to their limits. 663 A court cannot impose structural relief, or approve a consent decree providing for it, and assume that the remedy will implement itself. Even the use of masters, monitors, or trustees will not insulate the judge from mvolvement in the routime problems of the remedy's implementation; at best it only reduces that involvement. The judge therefore must be prepared to become "a policy planner and manager." 664 As one commentator explained:

Implementation is an incremental, cyclical process of small steps, each followed by assessment or reaction and further adjustment. Courts must revise decrees repeatedly to cover unforeseen impediments or adverse consequences. . . . Remedial decrees have not been static, comprehensive blueprints but rather evolving guides, constantly growing and changing. ${ }^{665}$

\section{CONCLUSION}

This Article has explored the nature of corruption and racketeering within the American labor inovement and has examined the inany different approaches to the problem that Congress, the courts, and the labor inovement itself have developed over the years. The structural injunctions and court-imposed trusteeships now available under the civil provisions of the federal RICO statute are among the most important of these remedies because of their potential effectiveness if used properly and their obvious danger to an independent labor novement if abused.

It is important to reiterate that the corruption and racketeering discussed in this Article are the exception, not the rule, in American unions. At the same time, lowever, significant segments of the labor moveinent,

662. If eliminating labor racketeering is indeed a "compelling state interest," the government should be willing to pay for it. See Association for Union Democracy, The Government's RICO Suit Against the Teamsters, UNION DemocRaCy ReV., Apr. 1989, at 3, 4.

663. Some have said, beyond their limits. See, e.g., Horowitz, supra note 25, at 1288.

664. Chayes, supra note 25 , at 1302.

665. Diver, The Judge as Political Powerbroker: Superintending Structural Change in Public Institutions, 65 VA. L. REV. 43, 63-64 (1979); see also Anderson, Implementation of Consent Decrees in Structural Reform Litigation, 1986 U. ILL. L. REV. 725, 737-63 (examination of the court's central role in implementing consent decrees). 
typified by the International Brotherhood of Teamsters, suffer tremendously from the infiltration and domination of organized crime. Unfortunately, denial is the response typically forthcoming from the house of labor, as illustrated by the recent reaffiliation of the Teamsters with the AFL-CIO without a word about the IBT's still rampant corruption. That is a dangerous state of affairs.

I have written this Article as a friend of the labor movement, in the belief that a labor movement free of corruption and racketeering will provide a stronger and more effective voice for the workers it represents. Nevertheless, I recognize that this Article will not be warmly received by many withm labor's ranks who beheve that public exposure of union corruption can only play into the hands of the labor movement's enemies. In my view, however, anti-umion forces will continue to exploit these failings whether or not supporters of the labor movement choose to confront them directly. Indeed, it is incumbent upon the labor movement itself to play a greater role im eliminating corruption and racketeering from its ranks, not only to free itself of unsavory and discrediting elements, but also to avoid more extensive and intrusive regulation by a federal government that lias not always been a friend of orgamized labor. As Walter Reuther of the United Auto Workers warned:

American labor had better roll up its sleeves, it had better get the stiffest broom and brush it can find, and the strongest soap and disinfectant, and it had better take on the job of cleaning its own house from top to bottom and drive out every crook and gangster and racketeer we find, because if we don't clean our own house, then the reactionaries will clean it for us. But they won't use a broom, they'll use an ax, and they'll try to destroy the labor movement in the process. ${ }^{666}$

666. Report of the Proceedings of the Sixteenth Constitutional Convention of the United Automobile, Aircraft, and Agricultural Implement Workers of America (1957), reprinted in ExCEPT To WALK FreE: Documents AND Notes IN THE History OF AMERICAN LABOR 291, 292 (A. Fried ed. 1974). 